UNIVERSIDADE DE SÃO PAULO

FACULDADE DE ODONTOLOGIA DE RIBEIRÃO PRETO

FÁBIO HEREDIA SEIXAS

\begin{abstract}
“AVALIAÇÃO DO USO DO LASER DE Er: YAG SOBRE A REMOÇÃO DA CAMADA DE “SMEAR” DAS PAREDES DOS CANAIS RADICULARES COM ACHATAMENTO MÉSIODISTAL SUBMETIDOS À INSTRUMENTAÇÃO ROTATÓRIA”
\end{abstract}

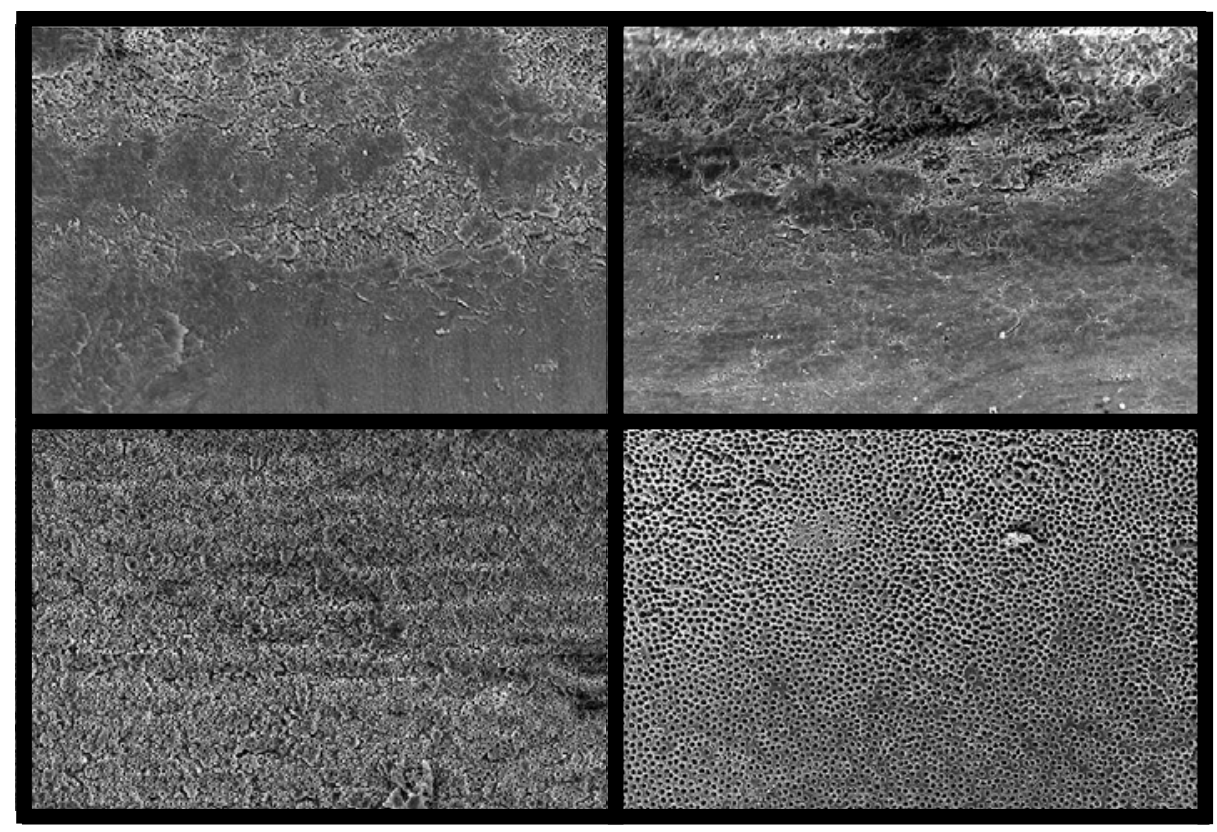

Orientador: Prof. Dr. Ricardo Gariba Silva

Ribeirão Preto 



\author{
UNIVERSIDADE DE SÃO PAULO \\ FACULDADE DE ODONTOLOGIA DE RIBEIRÃO PRETO
}

\title{
AVALIAÇÃO DO USO DO LASER DE Er: YAG SOBRE A REMOÇÃO DA CAMADA DE “SMEAR” DAS PAREDES DOS CANAIS RADICULARES COM ACHATAMENTO MÉSIO-DISTAL SUBMETIDOS À INSTRUMENTAÇÃO ROTATÓRIA
}

Dissertação apresentada à Faculdade de Odontologia de Ribeirão Preto da Universidade de São Paulo, para a obtenção do grau de Mestre em Odontologia, Programa Odontologia Restauradora, opção Endodontia.

Orientador: Prof. Dr. Ricardo Gariba Silva Orientado: Fábio Heredia Seixas

Ribeirão Preto 
Seixas, Fábio Heredia

Avaliação do uso do laser de Er: YAG sobre a remoção da camada de "smear" das paredes dos canais radiculares com achatamento mésio-distal submetidos à instrumentação rotatória. Ribeirão Preto, 2003.

97p.: il.; $28 \mathrm{~cm}$

Dissertação de Mestrado apresentada à FORP USP - Departamento de Odontologia Restauradora

Orientador Silva, Ricardo Gariba

CDU 616.314.18 - Endodontia 

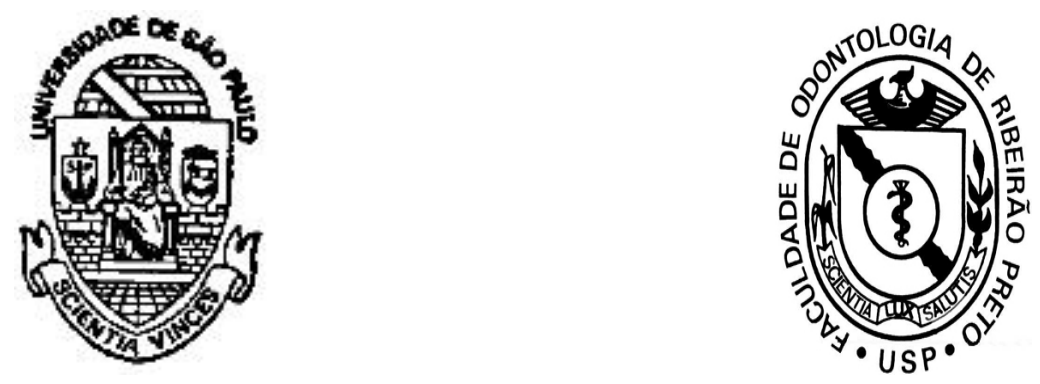

Este trabalho foi realizado no Laboratório de Pesquisa em Endodontia do Departamento de Odontologia Restauradora da Faculdade de Odontologia de Ribeirão Preto da Universidade de São Paulo, apoio FAPESP Processo 99/07904-3 e CNPq (bolsa mestrado). 

"Deus fazei de mim, não só mais um com título de mestre, mas, um real merecedor da condição de aprender e ensinar todos os dias de minha vida e, também, de ter discernimento para escolha dos melhores caminhos....." 



\section{DEDICATÓRIA}



A Deus por me proteger dos obstáculos que a vida oferece, carregando-me em seus braços, iluminando e conduzindo-me nos difíceis momentos de escolha. 

A minha filha Isabela, a quem dedico com todo meu carinho este trabalho, pelas inúmeras atitudes de amor e compreensão, imprescindíveis para a minha vontade de aprender e crescer.

A minha esposa Letícia, fiel companheira, pela paciência, amor, carinho e compreensão nos diversos momentos de nossas vidas e, principalmente, durante a realização deste trabalho. 

AGRADECIMENTOS 

A meus pais, Luis Filipe e Marisa pelo carinho, conselhos, ajuda e compreensão em todos os momentos de minha vida, obrigado por compartilhar mais esta conquista.

A meus avós Romualdo e Elza (in memórian) e Rubens e Carolina, exemplos de vida e dignidade, cujos ensinamentos fazem parte de mim. 

Ao meu orientador Prof. Dr. Ricardo Gariba Silva, pela orientação precisa e auxílio no desenvolvimento deste trabalho. 

A Faculdade de Odontologia de Ribeirão Preto da Universidade de São Paulo e seus professores, pela oportunidade de realizar este curso de mestrado.

A Faculdade de Medicina Veterinária da Universidade do Estado de São Paulo(UNESP) de Jaboticabal pela hospitalidade e auxílio na microscopia eletrônica de varredura.

Ao CNPq, pela concessão da bolsa de pesquisa.

Aos Professores Doutores Paulo César Saquy, Luis Pascoal Vansan, Wanderley Ferreira da Costa, Ricardo N. Savioli, Isabel C. Fröner, Antônio Miranda da Cruz Filho e Manuel D. de Souza Neto pela transmissão do conhecimento tão importante para a minha formação intelectual e clínica.

Ao amigo Reginaldo Santana da Silva pelos sábios conselhos nos vários momentos de dúvidas.

Ao amigo Alexandre Capelli, pelos sonhos, ideais e caminhos que juntos percorremos.

Ao amigo Prof. Danilo Mathias Zanello Guerisoli pelo apoio na elaboração deste trabalho.

Aos amigos e colegas Prof. Gilberto H. Fernandes, Prof. José Antônio Saadi Salomão, Profa Fabiana Careli de Castro, Profa. Melissa Andréa Marchesan, Prof.Júlio César E. Spanó, Prof. Eduardo Luiz Barbin e Prof. Antônio Luis Cussioli, pela convivência e incentivo em todas as horas.

Aos amigos e companheiros Fabrício Dias de Souza, Marcelo Sampaio Moura, Mônika Chaves, Rodrigo Maldonado, Sérgio A. Holanda e Silva e Valério de Barros Carvalho do curso de mestrado, de onde saio com saudades dos desafios e dificuldades que juntos superamos. 

Às funcionárias do Departamento de Odontologia Restauradora: Maria Amália Viesti de Oliveira, Luíza Godoi Pitol, Maria Isabel Cezário F. Miguel, Rosângela Angelini e Silvia Ferreira Camargo pelo carinho com que nos receberam e acolheram no dia-a-dia da PósGraduação.

A Maria Cristina M. Ferreira, bibliotecária, pela correção das Referências Bibliográficas.

Às secretarias da pós-graduação Isabel Cristina G. Sola e Regiane C. M. Saciolotto pela disponibilidade constante de ajuda. 

AGRADECIMENTO ESPECIAL 

Ao mestre, Prof. Dr. Jesus Djalma Pécora por saber que o professor leva o conhecimento ao aluno; porém... somente o mestre eleva o aluno ao conhecimento.

Obrigado pelos mais variados gestos de apoio, incentivo e conselhos, tanto os relativos à vida, como os de trabalho, bem como pela oportunidade de participar deste centro de pesquisa, onde obtive maior consciência e maturidade. 



\section{ÍNDICE}

RESUMO

SUMMARY

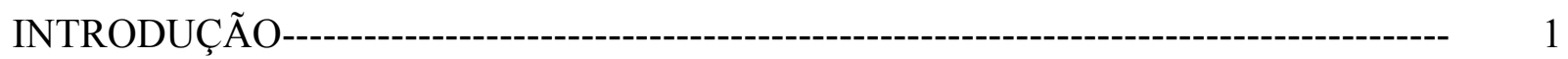

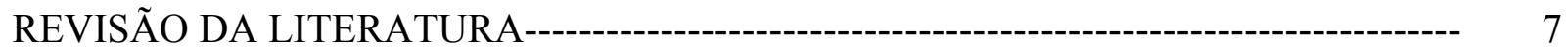

A - Importância do preparo biomecânico e remoção da camada de “smear"------------ 7

B - Evolução do NiTi na Endodontia---------------------------------------------------------- 14

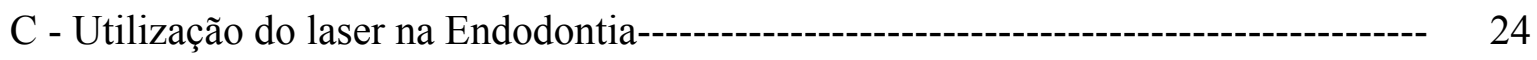

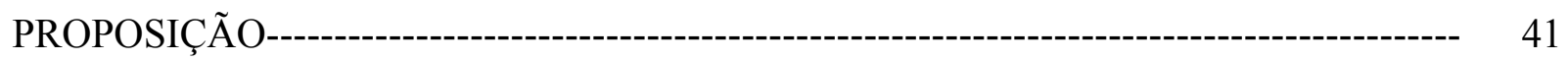

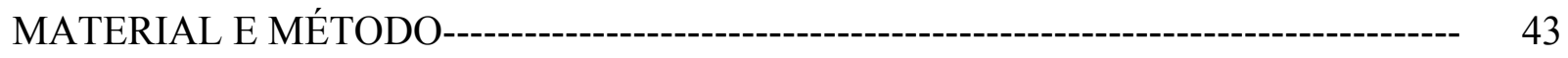

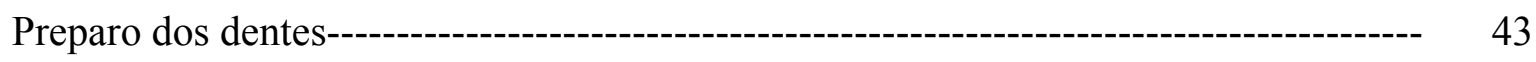

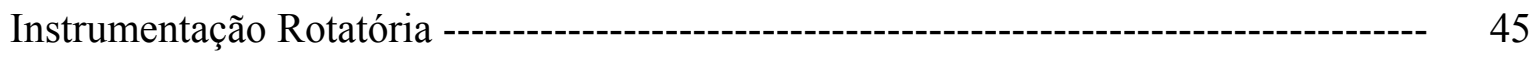

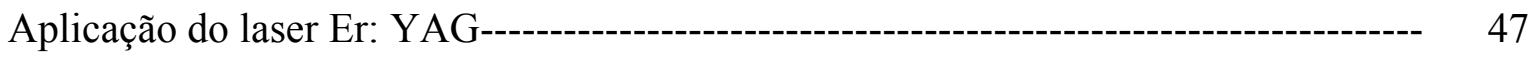

Cinemática da fibra óptica durante a irradiação com laser Er: YAG --------------------- 49

Preparo dos dentes para microscopia eletrônica de varredura------------------------------- 49

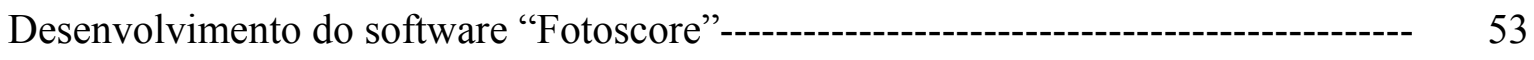

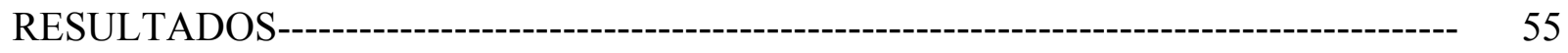

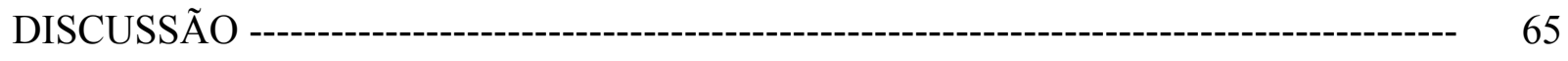

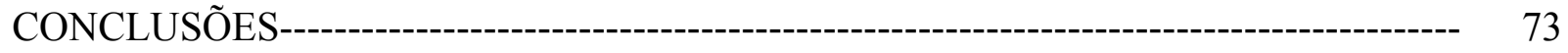

ANEXOS--------------------------------------------------------------------------------------------------- 75

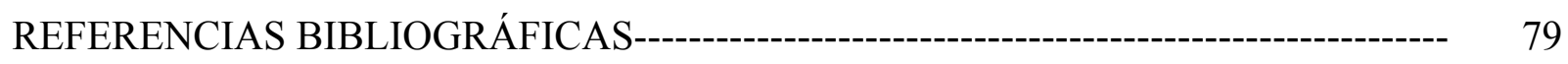



No tratamento endodôntico, várias fases de igual importância são necessárias para a realização de uma terapêutica bem sucedida, entre elas podemos citar a instrumentação. Apesar de todas as técnicas e instrumentos propostos para a Endodontia, o sucesso esperado ainda não foi alcançado. Tanto a instrumentação manual quanto à rotatória não resulta na limpeza das áreas polares dos canais radiculares com achatamento mésio-distal. No intuito de obter melhor resultado clínico, avaliou-se "in vitro" a remoção da camada de "smear" das paredes dos canais radiculares de 40 dentes incisivos inferiores portadores de achatamento mésio-distal submetidos à instrumentação rotatória por meio da técnica "Free Tip 
Preparation", utilizando o laser de Er: YAG nos parâmetros de 140 e 250 mJ. Para tanto, a fibra óptica do aparelho foi deslocada lentamente, com velocidade de $2 \mathrm{~mm} / \mathrm{s}$, até o orifício cervical na câmara pulpar, na parede vestibular e lingual da raiz; e sua eficácia na remoção da "smear" foi comparada aos grupos onde se utilizou apenas Hipoclorito a 2,5\% e Hipoclorito de sódio a 2,5\% alternado com EDTA a 17\%. Os dentes foram analisados por meio de microscopia eletrônica de varredura, e as fotomicrografias das áreas mais representativas dos terços médio e apical foram avaliadas por três examinadores diferentes, com grau mínimo de Mestre, que observaram a quantidade da camada de "smear" presente nas amostras em relação a três padrões. Os examinadores, sem que tivessem o conhecimento prévio de qual dos grupos estavam avaliando, atribuíram escores de 1 a 4 as fotomicrografias, de acordo com a quantidade da camada de "smear" visualizada. Os dados obtidos foram submetidos à análise estatística não-paramétrica, comparando-se os diferentes grupos estudados (teste de KruskalWallis) e os terços radiculares (teste de Wilcoxcon). Os resultados mostraram que, quanto à quantidade da "smear" encontrada nos grupos estudados, o grupo que utilizou Hipoclorito a 2,5\% alternado com EDTA apresentou os canais radiculares mais limpos seguido do grupo do laser $250 \mathrm{~mJ}$ e posteriormente pelos grupos do laser Er: YAG a $140 \mathrm{~mJ}$ e do hipoclorito a 2,5\%, que não apresentaram diferença estatisticamente significante entre si. Quanto aos terços, o apical apresentou maior quantidade da "smear" em comparação com o terço médio ( $\mathrm{p}<$ $0,01)$.

PALAVRAS-CHAVE: Smear Layer, instrumentação rotatória, laser Er: YAG e Endodontia. 
Manual or rotary instrumentation techniques do not efficiently clean mesio-distal flattened root canals. This study evaluated, in vitro, smear layer removal of 40 mesio-distal flattened root canals after rotary instrumentation. The teeth were then divided into 4 groups: group 1: rotary instrumentation and $2.5 \%$ sodium hypochlorite used as irrigating solution; group 2: instrumented as group 1 and followed by Er: YAG laser irradiation $(140 \mathrm{~mJ}$ input $/ 10 \mathrm{~Hz}$ ), withdrawn at $2 \mathrm{~mm} / \mathrm{s}$ from the apical to the cervical region touching the buccal walls the procedure was then repeated for the lingual wall); group 3: instrumented as group 1 and followed by Er: YAG laser irradiation $(250 \mathrm{mJinput} / 10 \mathrm{~Hz})$ withdrawn at $2 \mathrm{~mm} / \mathrm{s}$ from the 
apical to the cervical region touching the buccal walls the procedure was then repeated for the lingual wall) and group 4: instrumented as group 1 and alternated with 17\% EDTA Teeth were split longitudinally and prepared for examination under scanning electron microscopy. Scores from 1 to 4 were given to the fotomicrographs by three independent evaluators, and these data was submitted to statistical analysis. The teeth where alternated 17\% EDTA were used (group 4) showed less amount of smear layer, followed by the group irradiated with $250 \mathrm{mJinput} / 10 \mathrm{~Hz}$ (group 3), the group irradiated with $140 \mathrm{~mJ}$ input/10Hz and the group where only sodium hypochlorite was used. The apical third presented more smear layer than the middle third $(\mathrm{p}<00.1)$

KEY-WORDS: Smear Layer, Rotary instrumentation, Er: YAG laser and Endodontics. 
A complexidade da anatomia dos canais radiculares, com suas reentrâncias e a presença de canais laterais e acessórios, faz com que os microrganismos possam estar ali localizados, dificultando assim a limpeza e desinfecção do sistema de canais. Os instrumentos endodônticos utilizados na instrumentação manual não têm demonstrado bons resultados quanto à limpeza das paredes dos canais radiculares e, portanto, exige-se a ação simultânea de soluções auxiliares durante a sua utilização (Kutler, 1955; Gutierrez \& Garcia., 1968; Davis et al., 1972; Moodnik et al., 1976; Shilder, 1974; Walton, 1976). 
$\mathrm{Na}$ tentativa de solucionar os problemas encontrados no preparo biomecânico dos canais radiculares, várias técnicas manuais foram propostas, tais como: Manipulação Racional do Endoductodôncio (Badan, 1949); Step-Preparation (Clem, 1969); Incremental Instrumentation (Weine et al., 1970); Flare Preparation e Step-Preparation (Weine, 1972); Telescope Preparation (Martin, 1974); Cleaning and Shaping (Shilder, 1974); Serialization (Brilliant \& Christie, 1975); Step-Back Filling (Walton, 1976); Técnica da Universidade de Oregon (Pappin, 1978 apud De Deus, 1992, p.337); Step-Back Enlargement (Mullaney, 1979); Reversal Flaring (Weine, 1982); Balanced Force (Roane, 1985); Telescópica Modificada (De Deus, 1986); Técnicas Mistas de Preparo do Canal Radicular (Holland et al., 1991); Técnica de Movimentos Oscilatórios (De Deus, 1992) e Técnica dos Movimentos de Rotação Alternada (Siqueira, 1997).

Conforme afirmam Siqueira et al. (1997), nos dentes portadores de raízes com achatamento mésio-distal, os canais radiculares apresentam áreas de difícil limpeza tanto pelas técnicas manuais, quanto pelas ultra-sônicas.

Observa-se que, apesar de todas as técnicas acima citadas, a instrumentação manual parece limitar a obtenção de melhores resultados na limpeza dos canais radiculares, além do que resulta em um procedimento demorado e estressante (Lopes \& Siqueira., 1999).

Outro problema encontrado entre os profissionais da área era a dificuldade da instrumentação de canais extremamente curvos, pois as limas de aço-inox, até mesmo as flexíveis, confeccionadas a partir do mesmo material dos instrumentos anteriores, em determinados diâmetros, não possuíam a flexibilidade e elasticidade necessárias e, na maioria das vezes, transportavam o canal radicular, resultando em uma série de problemas na terapêutica tais como “zip” e perfurações (Serene et al., 1995). 
Pesquisando as diversas ligas existentes, Buehler \& Wang lançaram em 1963 a liga de NiTi no Naval Ordinance Laboratory (NOL), em Silver Springs, Maryland. A princípio, por suas propriedades físicas e mecânicas como flexibilidade, elasticidade e resistência a mudanças bruscas de temperatura, essa liga era utilizada na confecção de antenas para a NASA (Serene et al., 1995).

Civjan et al. (1975) foram os primeiros pesquisadores a sugerir o uso da liga de níqueltitânio nas aplicações médicas e odontológicas, mas, no entanto, foram Walia et al. (1988) os pioneiros a estudar essa liga na Endodontia, desenvolvendo limas endodônticas a partir de fios ortodônticos por um processo de micro-usinagem. Este processo na confecção destas limas se fazia necessário, uma vez que estas ligas, como já afirmado anteriormente, apresentam como propriedades a memória elástica e flexibilidade, não podendo desta forma sofrer torção.

Assim sendo, com as ligas de Ni-Ti, foi possível a criação de novos conceitos quanto à conicidade ("taper"), novos desenhos da secção transversal, maior flexibilidade nos instrumentos e menor capacidade de corte. No entanto, somente em 1992 estas limas foram fabricadas em escala industrial.

Na busca do aprimoramento e rapidez na terapêutica endodôntica, a instrumentação rotatória acionada a motor foi desenvolvida, e os instrumentos de NiTi sofreram evolução, sendo então fabricados tanto para o sistema manual quanto para o acionado a motor elétrico ou pneumático.

A instrumentação rotatória deixou de ser tratada apenas como pesquisa, tornando-se realidade nos consultórios, com o objetivo de melhorar o resultado no preparo dos canais radiculares. Devido a esse sucesso, várias Faculdades de Odontologia dos Estados Unidos da América do Norte estão ensinando estas técnicas em cursos de graduação, como a Universidade do Tennessee, a Universidade de Ciências da Saúde de Portland e a 
Universidade do Texas em Houston, visando ao aumento da produtividade e à diminuição dos erros (Buchanan, 2001).

A instrumentação, contudo, produz resíduo constituído de substância amorfa que se adere às paredes do canal radicular levando o nome de "smear layer", ou camada de "smear" e, quando impactado no interior dos túbulos dentinários, recebe o nome de "smear plug" (Mader et al., 1984; Sen, 1995).

Vantagens e desvantagens da remoção ou não da "smear" após a instrumentação do canal radicular são questões ainda controversas. Para Evans \& Simon (1986), a presença ou não da camada de "smear" não tem efeito significativo em relação ao selamento apical.

Alguns benefícios prováveis da manutenção da "smear", como o selamento e o bloqueio dos túbulos dentinários, isolando e destruindo os microorganismos presentes e impedindo a penetração de outros, foram salientados por Lopes \& Siqueira (1999).

Por outro lado, de acordo com Goldberg \& Abramovich (1977), Genttlemann et al. (1991), Sauders \& Sauders (1995), Calt \& Serper (2000) e Hata et al. (2001), a presença da camada de "smear" retarda a infiltração das soluções irrigantes, medicamentos e cimentos obturadores para dentro dos túbulos dentinários, o que não seria vantagem na terapêutica segundo os pesquisadores citados.

Quanto à limpeza dos canais radiculares proporcionada pela instrumentação rotatória, vários pesquisadores dentre eles Bertrand et al. (1999), Gambarini (1999) e Peters \& Barbacow (2000) têm avaliado, por meio da microscopia eletrônica de varredura, seus eficientes resultados na remoção da "smear" e "débris". No entanto, em relação aos canais com achatamento de raiz, Barbizan et al. (2002) salientaram o insucesso da instrumentação rotatória na remoção da camada de "smear" em regiões polares dos canais radiculares. 
Durante o preparo biomecânico, a solução auxiliar irrigante é essencial para a obtenção da limpeza e desinfecção do sistema de canais radiculares. A interação de fatores físicos e químicos intensifica o processo de sanificação e modelagem dos canais radiculares, removendo restos de sangue, polpa, detritos e raspas de dentina tanto da câmara pulpar quanto dos túbulos dentinários, agindo também como lubrificante para a utilização dos instrumentos endodônticos e na neutralização dos conteúdos tóxicos do sistema de canais radiculares (Pécora et al., 1999).

O hipoclorito de sódio é largamente recomendado e mundialmente aceito como solução irrigante para o tratamento dos canais radiculares devido as suas propriedades bactericida, na dissolução dos tecidos orgânicos, desodorizante e clarificadora (De Deus, 1992).

Observando a ação do hipoclorito de sódio sob o aspecto de limpeza, desinfecção, na dissolução de tecido, biocompatibilidade, aumento de permeabilidade dentinária e concentração da solução, inúmeros trabalhos foram realizados, dentre eles, podem ser citados: Marshall (1960), Stewart et al. (1969), Shih et al. (1970), Senia et al. (1971), Robazza (1973), Nery et al. (1974), Martin \& Spring (1975), McComb \& Smith (1975), Trepagnier et al. (1977), Hand et al. (1978), Cunningham \& Joseph (1980), Wennberg (1980), Cunninghan \& Balekjian (1980), Abou-Rass Piccinino (1982), Moorer \& Wesselink (1982), Pécora (1985), Fogel \& Pashley (1990), Cheung \& Stock (1993), Savioli et al. (1993), Barbosa et al. (1994) e Perez et al. (1996); Marchesan et al. (1998), Spanó (1999) e Barbin (1999).

Porém, quando é utilizada a instrumentação rotatória, o preparo endodôntico é realizado em menor tempo, a concentração da solução de hipoclorito de sódio tem de ser aumentada, haja vista que sua permanência em contato com as paredes do canal radicular será diminuída 
(Lopes \& Siqueira, 1999), e um tempo maior se faz necessário para que de tal solução, sejam aproveitadas todas as boas qualidades anteriormente mencionadas.

Pesquisas realizadas por Bertrand et al. (1999) mostraram que o hipoclorito de sódio isoladamente não é eficiente na remoção da "smear". No entanto, sua combinação com EDTA (etileno diamino tetra acético sal dissódico) tem sido recomendada para a remoção deste resíduo (Yamada et al., 1983; Baumgartner \& Mader, 1987; Pécora et al., 1992; Pécora et al., 1993; Pécora, et al., 1999 e Calt \& Serper, 2000).

Com o avanço da tecnologia, diversas técnicas têm sido propostas para a remoção da "smear", dentre elas o uso do laser de alta potência (Machida et al., 1995; Takahashi et al., 1996; Blum \& Abadie, 1997; Ebihara et al., 1998; Camargo et al., 1998; Takeda et al., 1998).

Entre os inúmeros tipos de laser existentes na atualidade, o de Er: YAG (Érbio: ÍtrioAlumínio-Granada) é um dos mais eficientes na remoção da camada de "smear" dos túbulos dentinários devido ao seu comprimento de onda $(2,94 \mu \mathrm{m})$, que realiza a remoção desta camada das paredes do canal por ablação, ou seja, por micro-explosões das moléculas de água do tecido, "quebrando" a ligação do grupo OH da hidroxiapatita (Brugnera-Júnior \& Pinheiro., 1998; Kumazaki, 1998; Takeda et al., 1999; Shoji et al., 2000).

Com a disponibilização de recursos para auxiliar o profissional no preparo químicomecânico dos canais radiculares, no intuito de melhorar sua capacidade de limpeza e desinfecção, faz-se necessário o estudo abrangente de alguns destes, entre eles instrumentação rotatória, aplicação de soluções quelantes como o EDTA e aplicação do laser de Er: YAG sobre a remoção da camada de "smear". 
Para facilitar a compreensão, a revisão da literatura foi separada nos seguintes tópicos:

A - Importância do preparo biomecânico, na limpeza e remoção da camada de "smear";

B - Evolução do NiTi na Endodontia;

C - Utilização do laser na Endodontia;

\section{A - Importância do preparo biomecânico, na limpeza e remoção da camada de "smear":}

No tratamento endodôntico, não existe a fase mais importante. Existe, sim, um conjunto de fases que proporcionará o sucesso na terapêutica. No entanto, este sucesso só será obtido fundamentalmente pelo preparo bio-químico-mecânico, desinfecção e obturação dos canais radiculares. 
Coolidge (1929) afirmava que o ato de limagem, irrigação e aspiração são artifícios mecânicos que retiram parte dos restos pulpares, raspas de dentina, tecidos necrosados e microrganismos, porém, faz-se necessária a utilização de um auxiliar químico com o objetivo de melhorar a limpeza e a desinfecção do canal radicular.

Hall (1930) considera a limpeza cirúrgica do canal radicular, em condições assépticas, como a primeira e verdadeira etapa para o sucesso, e recomenda a técnica do preparo dos canais radiculares de cervical para apical.

Walker (1936) desenvolveu um estudo sobre a capacidade de limpeza promovida pelo hipoclorito de sódio a 5\% na desinfecção de canais necrosados.

Grossman (1943), com base nos trabalhos de Walker (1936) e Grossman \& Meiman (1941), preconizou uma técnica de irrigação de canais radiculares que utilizava o uso alternado do hipoclorito de sódio a 5\% com o peróxido de hidrogênio a 3\%. A reação química entre essas duas soluções dá como resultado final à formação de água, cloreto de sódio e oxigênio nascente. A reação é efervescente e favorece a eliminação dos resíduos do interior do canal radicular.

Grossman (1956) afirmou que não importa a largura original do canal. A instrumentação biomecânica é o método mais eficiente na limpeza, retificação e alisamento das superfícies dos canais radiculares.

Østby (1957), com base no trabalho de Nikiforuk \& Sreebny (1953), indicou o sal dissódico do ácido etilenodiaminotetracético (EDTA) para a instrumentação dos canais radiculares, uma vez que, sua ação quelante permite formular uma solução auxiliar para a instrumentação do canal radicular. Por ser biologicamente compatível com os tecidos, o autor preconizava o seu emprego em substituição aos ácidos inorgânicos até então utilizados para a instrumentação de canais atresiados. 
Chapman et al. (1968), aconselham que um canal radicular deve estar o mais asséptico possível antes de se iniciar a instrumentação, pois verificaram em seus estudos "in vitro", que havia extrusão de material através do forame apical durante a instrumentação dos canais radiculares, tanto com o uso de limas como de alargadores.

Baker (1975) avaliando, por meio de microscopia eletrônica de varredura a limpeza dos canais radiculares, salienta que é mais importante a quantidade de solução irrigante utilizada, ou seja, seu volume e não o grupo químico da solução.

Walton (1976) avaliou, por meio de microscopia óptica, a limpeza dos canais radiculares promovida pelas diversas técnicas de instrumentação e demonstrou que nenhuma delas foi totalmente eficiente, principalmente no terço apical.

Trepagnier et al. (1977) estudaram, "in vitro", os efeitos das várias concentrações e tempo de reação da solução de hipoclorito de sódio a 5\% como solvente de tecido, utilizando a mensuração do conteúdo de hidroxiprolina para verificar a eficiência da solução. Concluíram que o hipoclorito de sódio a 5\% é um potente solvente de tecido, e que a diluição dessa solução com água, em partes iguais, não afeta, apreciavelmente sua ação solvente.

A presença ou não da camada de "smear" tem causado controvérsias na literatura uma vez que sua presença é benéfica, porque reduz a permeabilidade da dentina e previne ou diminui a penetração de bactérias para dentro dos túbulos dentinários. Entretanto, ela pode ser considerada prejudicial, pois não permite que a solução irrigante, medicamentos e materiais obturadores penetrem nos túbulos dentinários (Goldberg \& Abramovich, 1977; Calt \& Serper, 2000).

Thé (1979) estudou a capacidade de ação de solvência tecidual promovida pelo hipoclorito de sódio em tecidos necrosados e concluiu que esta ação é diretamente proporcional ao volume e concentração desta solução. 
Machtou (1980) relatou que o sucesso da terapia endodôntica repousa sobre a tríade preparo biomecânico, controle da infecção e obturação dos canais radiculares. Esse autor salientou, de modo enfático, que se devem eliminar todos os resíduos e os microrganismos do interior dos canais radiculares e afirmou que a ação da solução irrigante depende de dois fatores: o contato entre a solução com os resíduos e o tempo de ação.

Koskinen et al. (1980) em seus estudos, verificaram que o hipoclorito de sódio dissolvia a pré-dentina das paredes do canal radicular.

Gordon et al. (1981) estudaram o efeito solvente de soluções de hipoclorito de sódio nas concentrações de 1, 3 e 5\% sobre o tecido pulpar bovino vital e não vital. Os autores observaram que, quanto maior a concentração da solução de hipoclorito de sódio, tanto menor seria o tempo de solvência dos tecidos vivos e necróticos.

Moorer \& Wesselink (1982) estudaram o fluxo líquido, o potencial hidrogeniônico e a área de contato na capacidade de dissolução da solução de hipoclorito de sódio. Observaram que o princípio ativo do hipoclorito de sódio dependia da quantidade de moléculas de ácido hipocloroso $(\mathrm{HOCl})$ não dissociadas. Esse ácido é responsável pela forte cloraminação e oxidação de matérias orgânicas, tais como tecidos e microrganismos. O ácido hipocloroso é consumido na interação com matéria orgânica.

Yamada et al. (1983), com auxílio da microscopia eletrônica de varredura, correlacionaram a instrumentação com diferentes volumes de diversas soluções irrigantes como: solução salina (controle), hipoclorito de sódio a 5,25 \%, EDTA a 17 e a 8,5\%, e o ácido cítrico a 25\%. Os resultados mostraram que a associação de $10 \mathrm{ml}$ de EDTA a 17\% com $10 \mathrm{ml}$ de hipoclorito de sódio a 5,25\% revelou-se eficiente na remoção da "smear", apresentando inclusive grande eficiência na remoção de "débris" superficiais. 
Compartilhando desse resultado, Saquy (1991), ao estudar a capacidade quelante do EDTA e da associação EDTA + solução de Dakin, comprovou que a associação destas soluções poderia ser realizada com sucesso, sem que uma ou outra se neutralizasse.

Baumgartner \& Mader (1987) relataram que a combinação do hipoclorito de sódio com EDTA (etileno diamino tetra acético sal dissódico) causa a dissolução progressiva das áreas peritubular e intertubular da dentina aumentando o diâmetro do orifício dos túbulos das paredes do canal instrumentado, fazendo com que eles passem de 2,5 para $4 \mu \mathrm{m}$.

Garberoglio \& Becce (1994), afirmam, com propriedade, que os remanescentes da camada de "smear" podem conter bactérias, toxinas, "débris", tecidos vitais, produtos da saliva e outros contaminantes. Portanto, a remoção dessa camada seria necessária.

Heard \& Walton (1997) compararam, por meio de microscopia eletrônica de varredura, as técnicas de escalonamento sem prévia dilatação cervical; escalonamento com prévia dilatação cervical e escalonamento com dilatação cervical prévia associada à irrigação final com ultra-som, em canais de molares humanos com curvatura moderada ( 15 a $\left.35^{\circ}\right)$. $\mathrm{O}$ trabalho avaliou a remoção de "débris" e "smear" nos níveis apical, médio e cervical. Os autores verificaram que não houve diferença significativa entre as técnicas. Todas limparam melhor o terço médio e nenhuma removeu completamente a camada de "smear".

Só et al. (1997) avaliaram a habilidade de dissolução tecidual das soluções de hipoclorito de sódio de diferentes fabricantes, concluindo que a capacidade de dissolução tecidual é diretamente proporcional à concentração da solução de hipoclorito de sódio e que o hipoclorito de sódio a 0,5\% apresentou capacidade limitada de dissolução.

Hulsmann et al. (1997) avaliaram nove técnicas diferentes de instrumentações automatizadas: Endoplaner, Excalibur, Giromatic, Intra-Endo 3-LDSY, Canal Finder System, Canal Leader 2000, Endolift, Ultra-som Piezon Master 400 com H2O2 (5\%) como agente 
irrigante e outro grupo com hipoclorito de sódio a 1\% e uma técnica manual utilizando limas Hedströem. Foram utilizados 150 incisivos inferiores humanos recém-extraídos, divididos em dez grupos de 15 dentes cada. Depois de instrumentados, os dentes foram cortados longitudinalmente e examinados em microscópio eletrônico de varredura. Concluíram que nenhuma das técnicas resultou na remoção completa da "smear" do interior dos canais radiculares, sendo que as técnicas com ultra-som produziram melhores resultados.

Guerisoli et al. (1998) investigaram a ação das soluções de hipoclorito de sódio nas concentrações de 0,$5 ; 1 ; 2,5$ e 5\% sobre a estrutura dentinária mineralizada e desmineralizada, pelo tempo de uma hora. Esses autores constataram que a dentina mineralizada apresentava perda de massa tecidual de modo estatisticamente semelhante para todas as concentrações das soluções estudadas. Porém, a dentina desmineralizada (colágeno) sofria perda de massa de modo diretamente proporcional à concentração da solução, ou seja, quanto maior a concentração da solução de hipoclorito de sódio, tanto maior a perda de massa da dentina desmineralizada.

Hata et al. (2001) avaliaram por meio de microscopia eletrônica de varredura, a limpeza das paredes dos canais radiculares promovida pela instrumenção manual "Step-Back" com o auxílio da associação das soluções de hipoclorito de sódio a 5\%, EDTA a 15\%, e a solução de “Oxidante Potencial Water” (OPW). Os autores concluíram que a solução de EDTA a 15\% alternada com hipoclorito de sódio a 5\% promoveu maior remoção da "smear" das paredes dos canais radiculares. A irrigação alternada de hipoclorito de sódio e OPW também foi eficiente na remoção da camada de "smear" e "débris", porém apresentou resultado inferior comparada à associação mencionada anteriormente.

Guerisoli et al. (2002) avaliaram a remoção da camada de "smear" por diferentes soluções irrigadoras sob agitação ultra-sônica. Para este estudo, foram necessários 20 dentes 
incisivos inferiores humanos que foram divididos em 4 grupos. Os grupos 1, 2 e 3 foram instrumentados respectivamente, com água destilada, hipoclorito de sódio a 1\% apenas ou associado ao EDTA a 15\%. O grupo restante não foi instrumentado, sendo apenas irrigado pela solução de hipoclorito de sódio a 1\% associado ao EDTA a 15\%. Na utilização do ultrasom, a lima \# 15 foi energizada e realizada em todos os grupos movimentos de pequena amplitude nas paredes dos canais radiculares. Findo este preparo, os dentes foram seccionados no sentido longitudinal e, seus terços apical, médio e cervical avaliados por meio da microscopia eletrônica de varredura. Os resultados mostraram paredes cobertas por "smear" nos grupos onde se utilizou água destilada e hipoclorito de sódio a $1 \%$ como solução irrigadora. Os canais irrigados com hipoclorito de sódio a $1 \%$ associado ao EDTA a 15\% proporcionaram menor quantidade de "smear" em suas paredes $(\mathrm{p}<0,001)$. Em relação aos terços, não houve diferença estatisticamente significante quanto à presença da camada de "smear".

Torabinejad et al. (2003a) estudou o efeito da solução composta da associação de tetraciclina, um ácido e um detergente (MTAD) como irrigação final das superfícies das paredes dos canais radiculares previamente instrumentados. Quarenta e oito dentes unirradiculares humanos foram utilizados e preparados pela combinação da técnica "StepBack" passiva e instrumentação rotatória com limas de NiTi taper 0,04. Como auxiliares dessa instrumentação, utilizou-se água destilada ou solução de hipoclorito de sódio a 5,25\%. Na irrigação final, os grupos receberam água destilada, hipoclorito de sódio a 5,25\%, EDTA a 17\% ou a solução de MTAD. A presença ou não da camada de "smear", assim como erosões na estrutura das paredes dos canais, foram averiguadas por meio da microscopia eletrônica de varredura. Os resultados mostraram que a solução MTAD foi eficiente na remoção da "smear" e, nos grupos em que se utilizou irrigação auxiliar com solução de hipoclorito de sódio 
finalizado com irrigação final com a solução de MTAD, não foi observada mudança significante na estrutura dos túbulos dentinários.

Torabinejad et al. (2003b) estudou o efeito de várias concentrações de hipoclorito de sódio na irrigação intracanal e posteriormente irrigação final com solução de mistura de tetraciclina, ácido e detergente (MTAD). Foram necessários 80 dentes mono e multirradiculares humanos. Os espécimes foram instrumentados com limas rotatórias de NiTi, irrigados com água destilada e quatro diferentes concentrações de hipoclorito de sódio ou MTAD e, posteriormente, a irrigação final foi realizada com hipoclorito de sódio a 5,25\%, água destilada, EDTA a 17\% ou MTAD. A presença ou ausência da "smear", assim com de erosões nas superfícies dos canais radiculares, foi avaliada por meio de microscopia eletrônica de varredura. Os resultados mostraram que, embora o MTAD tivesse removido mais "smear", quando usado como solução intracanal, alguns remanescentes orgânicos da "smear" permaneceram espalhados pelas paredes dos canais radiculares. A eficiência do MTAD na completa remoção da "smear" era aumentada quando baixas concentrações de hipoclorito de sódio auxiliavam no preparo do canal radicular e, posteriormente, usava-se o MTAD como irrigação final. Mudanças significativas na estrutura das paredes dos canais não foram observadas.

\section{B - Evolução do NiTi na Endodontia:}

O estudo sobre a liga de níquel-titânio iniciou-se em 1938 com Vagel \& Wallbaum. Mas somente em 1963, Buehler \& Wang lançaram a liga de NiTi no Naval Ordinance Laboratory (NOL), em Silver Springs, Maryland. Primeiramente, essa liga foi utilizada na confecção de cascos de navios e submarinos, em função de suas propriedades físicas que possibilitavam: 
resistência à torção, flexões e alterações bruscas de temperatura. Posteriormente, também foi utilizada pela NASA-USA na confecção de antenas e satélites (Serene et al., 1995).

Civjan et al. (1975) foram os pioneiros a estudar e indicar a liga de niquel-titânio para Odontologia devido suas propriedades físicas e mecânicas. No entanto a primeira investigação sobre o uso desta liga na Endodontia foi realizada por Walia et al. (1988). Estes autores pesquisando sobre as ligas de NiTi usadas em Ortodontia, desenvolveram limas endodônticas a partir de fios ortodônticos dessa liga, com um percentual atômico entre $50 \%$ e $55 \%$ de níquel, pois segundo os mesmos, os tipos de ligas de NiTi disponíveis no mercado possuíam diferentes propriedades mecânicas. Ao compararem as limas de NiTi número 15 de secção triangular, com limas de aço-inoxidável de mesmo número e secção, os autores observaram que ao aplicar movimentos rotatórios no sentido horário e anti-horário, as limas de NiTi apresentaram-se muito mais flexíveis e mais resistentes à fratura do que as de aço-inoxidável. Esses resultados demonstraram que as limas de níquel-titânio possuíam duas grandes propriedades: a super flexibilidade e o chamado efeito memória de forma. Mas foi somente em 1992, que se iniciou a fabricação dos instrumentos endodônticos em níquel-titânio.

Serene et al. (1995) compararam as propriedades mecânicas dos instrumentos de NiTi e instrumentos de aço-inoxidável. Os autores salientam que os instrumentos de NiTi são superiores no que diz respeito às forças externas, tais como resistência à fadiga, fluência, fratura, torção, flexão, tração e compressão. Afirmam, também, que o efeito memória de forma possibilita à liga de NiTi passar da fase austenítica para a martensítica, retornando à sua forma original (austenítica), uma vez removida a força que a deformou. A superelasticidade permite ao instrumento retornar à sua forma original após sofrer carga de deformação, diferente do observado com o aço-inoxidável, que sofre deformação permanente de forma que 
conseqüentemente, os instrumentos de níquel-titânio apresentaram flexibilidade extremamente superior comparada aos de aço-inoxidável.

Esposito \& Cunningham (1995) compararam a manutenção da forma original em canais radiculares curvos durante a instrumentação de quarenta dentes humanos extraídos, com limas rotatórias de NiTi, manuais de aço-inoxidável e manuais de níquel-titânio. A partir de um método radiográfico, concluíram que as limas de NiTi, tanto as do sistema manual como as do rotatório, foram estatisticamente superiores aos grupos de limas de aço-inoxidável, mantendo a forma original do canal quando o preparo era dilatado até a lima \#35, \#40 ou \#45 na porção apical.

Com o advento de instrumentos de níquel-titânio na Endodontia, os pesquisadores e clínicos trabalham com a possibilidade de se conseguir uma instrumentação segura dos canais curvos até instrumentos com maiores diâmetros $\mathrm{D}_{1}$ sem o transporte do forame (Esposito \& Cunningham, 1995; Serene et al., 1995).

Sahli et al. (1996) compararam instrumentos de níquel-titânio (Nitiflex $\left.{ }^{\circledR}\right)$ e $\left(\right.$ Naviflex $\left.^{\circledR}\right)$ com os de aço inoxidável $\left(\right.$ Flexofile $\left.^{\circledR}\right)$ e $\left(\right.$ Flex-R $\left.{ }^{\circledR}\right)$ analisando, quanto a torção e resistência à fratura. Concluíram que as limas de níquel-titânio possuem maior flexibilidade e menor resistência que as limas de aço-inoxidável.

Chan \& Cheung (1996) compararam os efeitos da instrumentação manual com limas de aço inoxidável tipo $\mathrm{K}$ em relação às limas tipo $\mathrm{K}$ de NiTi, em dentes extraídos de humanos moderadamente curvos, pela técnica manual cérvico-apical. Por meio da metodologia proposta por Bramante et al. (1987), concluíram que os dois tipos de limas removeram quantidades similares de dentina e ambas transportaram os canais, sendo que as de NiTi foram mais seguras na redução da quantidade de transporte através das zonas de perigo. 
Valli et al. (1996) avaliaram, por meio da microscopia eletrônica de varredura, a limpeza dos canais radiculares em incisivos centrais superiores humanos recém extraídos. Os dentes foram instrumentados com a técnica Canal Master e instrumentação com limas tipo K, para avaliarem a capacidade destas duas técnicas na limpeza das paredes dos canais radiculares. A conclusão deste trabalho esclarece que nenhuma das duas técnicas foi capaz de remover completamente a "smear" do interior dos canais radiculares, apesar da técnica do Canal Master ter obtido melhores resultados.

Siqueira et al. (1997) determinaram histologicamente a eficiência na limpeza de cinco diferentes técnicas de instrumentação no terço apical de canais curvos. Canais mesiais de molares inferiores recém-extraídos foram preparados de acordo com as seguintes técnicas: “Step-Back” com limas de aço inoxidável, "Step-Back" com limas de NiTi, ultra-som, força balanceada e Canal Master U. O terço apical dos canais foi processado histologicamente, e os cortes foram analisados para verificar a presença de tecido pulpar, pré-dentina e “débris". Os resultados não evidenciaram diferença estatística significante entre as técnicas. Além disso, verificou-se que nenhuma das técnicas foi totalmente eficiente a limpeza do sistema de canais radiculares, especialmente quando estes apresentavam alguma variação anatômica interna.

Thompson \& Dummer (1997a) determinaram a capacidade de modelagem de canais simulados do Sistema ProFile ${ }^{\circledR}$ taper .04 Série 29 com limas de NiTi. Um total de 40 canais simulados em diferentes formas em termos de ângulo e posição de curvatura foram preparados com o sistema ProFile ${ }^{\circledR}$ taper .04 Série 29 com a técnica "Crown-Down". Os autores descrevem a eficiência dos instrumentos quanto ao tempo de preparo, falha dos instrumentos, bloqueio por resíduos da instrumentação, perda de comprimento de trabalho e forma tridimensional dos canais. O tempo de preparo não foi influenciado significativamente pela forma do canal. Não ocorreu fratura de nenhum instrumento, mas 52 deles se deformaram, 
mas não foi possível verificar se isso ocorreu devido à natureza do experimento ou ao desenho da lima. A forma do canal não influenciou significativamente na deformação do instrumento. Nenhum canal foi bloqueado por resíduos de instrumentação e a perda de comprimento de trabalho foi, em média, $0,5 \mathrm{~mm}$ ou menos. Avaliação intracanal mostrou paredes lisas e com boa conicidade. O Sistema ProFile ${ }^{\circledR}$ permitiu o preparou do canal rapidamente e com boa forma tridimensional

Thompson \& Dummer (1997b) determinaram a habilidade de modelar um canal simulado do Sistema ProFile ${ }^{\circledR}$ taper. 04 Série 29 com limas de NiTi. Quarenta canais simulados em diferentes formas ângulos e posição de curvatura foram preparados com o Sistema ProFile ${ }^{\circledR}$ taper .04 Série 29 com a técnica "Crown-Down". Este trabalho descreve a eficiência dos instrumentos quanto à prevalência de aberrações no canal, quantidade e direção do transporte do canal e forma pós-instrumentação. Nenhum “zip”, perfuração ou zonas de perigo foram criadas apesar de 24 canais apresentarem proeminências na parede externa do canal. A incidência dessas proeminências variou significativamente $(p<0,001)$ entre as formas dos canais. Em pontos específicos ao longo do canal havia diferenças estatisticamente significantes $(p<0,001)$ em relação ao diâmetro e quantidade de material removido da parte interna e externa da curvatura.

Reddy \& Hicks (1998) analisaram “in vitro" a quantidade de extrusão de "débris" usando duas técnicas de instrumentação, manual e rotatória, em dentes pré-molares extraídos de humanos com mínima curvatura e canal único. No grupo I, os dentes foram preparados usando limas tipo K e movimento de limagem completado com escalonamento; no grupo II,

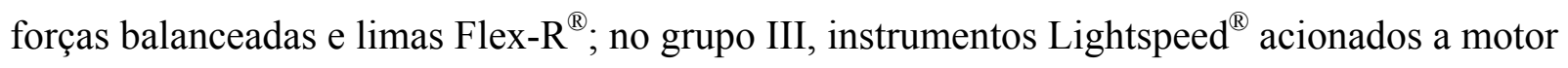
por rotação e no grupo IV, instrumentos Profile ${ }^{\circledR} .04$ série 29 também acionados a motor. Os "débris" foram coletados e analisados. Os autores concluíram que todas as técnicas 
produziram extrusão apical, sendo que os preparos com instrumentação manual provocaram extrusão de material significativamente maior, em comparação aos preparos com instrumentação rotatória.

Bryant et al. (1998a) determinaram a capacidade de modelagem do sistema ProFile ${ }^{\circledR} .04$ com limas de NiTi em canais simulados. Para este estudo, 40 canais simulados com quatro diferentes tipos de ângulos e posição de curvatura foram preparados usando a técnica "CrownDown" recomendada pelo fabricante. Este estudo descreve a eficiência de instrumentação no que diz respeito a tempo de preparo, falha de instrumento, perda de comprimento de trabalho e forma tridimensional do canal radicular. O tempo necessário para o preparo do canal foi de 5,2 minutos e não foi influenciado pela forma do canal radicular. Ocorreu a fratura de três instrumentos e três ficaram deformados. Nenhum canal foi bloqueado pela presença de resíduos de instrumentação. As impressões intra-radiculares mostraram batentes apicais e uniformidade de preparo, instrumentando de forma rápida e eficiente.

Bryant et al. (1998b) determinaram a capacidade de modelagem do sistema ProFile ${ }^{\circledR} .04$ com limas de NiTi em canais simulados. Quarenta canais simulados com quatro diferentes tipos de ângulos e posição de curvatura foram preparados usando a técnica "Crown-Down" recomendada pelo fabricante. Este estudo descreve a eficiência de instrumentação no que diz respeito à prevalência de aberração no canal, transporte, direção de transporte do canal e sua forma. De 37 canais, encontraram-se 9 "zips", mas nenhuma zona de perfuração foi encontrada. No que diz respeito à largura dos canais radiculares houve diferenças estatísticas quanto a diferentes tipos de curvatura de canais. Houve maior transporte do canal na região de curvatura e menor transporte na porção reta do canal. O sistema ProFile ${ }^{\circledR} .04$ produziu maior número de zips do que o esperado, entretanto não muito acentuados. 
Bertrand et al. (1999) avaliaram, por meio da microscopia eletrônica de varredura, a capacidade de remoção de "débris" e "smear" promovida pela técnica de instrumentação do canal radicular com o Sistema Quantec e instrumentação manual. Os autores verificaram que a limpeza do canal radicular foi mais eficiente com o Sistema Quantec do que com a instrumentação manual.

Gambarini (1999) analisou, por meio da microscopia eletrônica de varredura, a eficiência da combinação de EDTA $17 \%, \mathrm{NaOCl} 5 \%$ e tensoativo 1\% (Tritron) durante e após o preparo dos canais radiculares com limas de NiTi do sistema ProFile ${ }^{\circledR}$. Os autores concluíram que o uso de EDTA promoveu maior remoção de “débris", seguido do Tritron e NaOCl.

Schrader et al. (1999) descreveram, passo a passo, a utilização do sistema ProFile ${ }^{\circledR}$ de acordo com a técnica empregada pela Divisão de Endodontia de Zurich com a intenção de difundir e ensinar o uso desta instrumentação aos clínicos. Essa técnica envolve o preparo da porção coronária com brocas de Gates-Glidden e limas ProFile ${ }^{\circledR}$. Nesta sistemática o conjunto de habilidades é estabelecido após o preparo da região cervical do canal radicular.

Peters \& Barbakow (2000) avaliaram “in vitro”, por meio da microscopia eletrônica de varredura, a presença de "débris" e "smear" nos canais radiculares após o preparo com os instrumentos rotatórios do sistema Lightspeed ${ }^{\circledR}$ e ProFile ${ }^{\circledR}$. Para este estudo, 32 molares inferiores foram utilizados, estes dentes foram seccionados no sentido vestibular-lingual, destes, apenas 30 raízes mesiais e 2 raízes distais que apresentavam 2 canais foram selecionadas. Os dentes foram preparados com as seguintes soluções auxiliares: água (grupo A) e hipoclorito de sódio 5,25\% alternado com EDTA 17\% (grupo B). Após o preparo, as raízes foram seccionadas longitudinalmente e examinadas nos três terços. Quando a água foi utilizada como solução irrigadora, a média dos escores da presença de "débris" foi semelhante para os dois sistemas. Já para o uso do $\mathrm{NaOCl}$ alternado com EDTA, os dois sistemas tiveram 
resultados semelhantes no terço apical e coronário, mas houve diferença estatisticamente significante no terço médio. Quanto à presença da camada de "smear", os dois sistemas foram semelhantes com o uso da água e os terços apicais e médios, diferentes dos terços coronários quando utilizado $\mathrm{NaOCl}$ alternado com EDTA como solução irrigante.

Os resultados dos estudos realizados por Lumley (2000) sugere que, para melhorar a limpeza dos canais radiculares preparados com instrumentos de grande conicidade, deve-se finalizar o preparo com instrumentos de conicidade .02 com o diâmetro da ponta de 0,55 ou 0,60 mm, resultando em canais com menor quantidade de "débris" no terço apical.

Buchanan (2000) introduziu o conceito de variadas conicidades para o preparo de canais mais ergonômicos e previsíveis e demonstrou as vantagens do uso de instrumentos com maior "taper" ou conicidade, devido à dificuldade de preparo de um canal radicular ideal e de se ensinar com instrumentos endodônticos convencionais. Analisou as vantagens e desvantagens desse tipo de preparo, assim como a eficiência da obturação posterior. Demonstrou-se que variadas conicidades contribuem para o preparo adequado do canal radicular ideal quanto à forma e rapidez.

A instrumentação rotatória deixou de ser encarada como pesquisa e passou a ser realidade nos consultórios odontológicos inclusive no ensino Universitário. Algumas Universidades Norte Americanas, tais como Universidade do Tennessee, Universidade de Ciências da Saúde de Portland e a Universidade do Texas em Houston, visando o aumento da produtividade e a diminuição de erros, estão ensinando na graduação técnicas de instrumentação rotatória (Buchanan, 2001).

Barbizam et al. (2001) estudaram por meio de análise morfométrica a limpeza promovida pela instrumentação rotatória com limas de NiTi em incisivos portadores de achatamento mésio-distal. Para tanto, 10 incisivos inferiores foram utilizados e separados em 2 
grupos contendo 5 dentes cada. No grupo 1 , os dentes foram instrumentados por meio de limas rotatórias de NiTi acionadas por motor elétrico e o segundo grupo, os dentes foram instrumentados com limas manuais pela técnica "Crown-Down". Os autores verificaram que houve ineficiência de instrumentação devido ao grau de achatamento desses canais. Este resultado era explicado, pelo fato de que as limas não tocavam as paredes das regiões polares dos canais radiculares. Concluíram também que a técnica manual foi mais eficiente na limpeza que a rotatória.

Marchesan (2001) verificou que as variações da anatomia interna dos canais radiculares podem interferir no sucesso da terapêtica endodôntica devido ao fato de que em canais radiculares achatados, podem persistir remanescentes teciduais em istmos, reentrâncias e ramificações dificultando a execução das técnicas de instrumentação. O presente trabalho verificou a qualidade de limpeza dos canais radiculares, por meio da microscopia óptica, promovida pela técnica de instrumentação rotatória associada ao hipoclorito de sódio $0,5 \%$, HCT20 e clorexidina, em canais achatados no sentido mésio-distal. Doze incisivos centrais inferiores humanos foram divididos aleatoriamente em três grupos para que fossem instrumentados com o Sistema ProFile ${ }^{\circledR} .04$. A análise estatística evidenciou que os valores da porcentagem de limpeza para as diferentes soluções irrigantes foram estatisticamente diferentes entre si. Comparações duas a duas permitiram dispor as soluções irrigantes em ordem decrescente de eficiência na limpeza, ou seja, hipoclorito de sódio a $0,5 \%>$ clorexidina a $2 \%>$ HCT 20 .

Evans \& Simon (2001) avaliaram a remoção de polpa e de pré-dentina em canais radiculares de quarenta e seis molares e pré-molares. Estes dentes foram divididos em quatro grupos, que receberam os seguintes tratamentos: 1): "Step-Back", hipoclorito de sódio 3\%; 2): "Step-Back”, água; 3) Sistema Quantec, hipoclorito de sódio 3\%, e 4) Sistema Quantec e água. 
Estes autores concluíram que não houve diferença estatisticamente significante entre os grupos de instrumentos com água ou com hipoclorito de sódio.

Pécora et al (2002) estudando as seqüências de combinações dos diâmetros dos instrumentos de NiTi com o intuito de diminuir sua fratura na instrumentação dos canais radiculares, desenvolveram uma técnica que contraria a maioria das técnicas até hoje preconizadas. Os autores afirmam que uma das grandes causas que levam à fratura dos instrumentos é que, na maioria das técnicas, a ponta da lima, parte mais frágil do instrumento, sofre o maior estresse, uma vez que se realiza praticamente a técnica "Crown-Down" que é realizada no preparo com limas manuais. Utilizando essa técnica, a ponta do instrumento está sempre trabalhando, podendo até por vezes se prender, ficando então susceptível à fratura. Desta forma os autores criaram uma técnica onde o estresse da instrumentação é jogado para a região de maior resistência dos instrumentos, ou seja, a região cervical, porção esta que possui maior massa metálica, essa técnica levou o nome de "Free Tip Preparation" e preconiza a utilização de uma seqüência de limas rotatórias de NiTi, onde na maior parte a ponta do instrumento trabalha livre, servindo então apenas como guia.

Há, na atualidade, uma série de sistemas de instrumentação rotatória a disposição dos endodontistas, bem como peças de mão, que podem ser acionadas tanto por ar comprimido (instrumentação pneumomecânica) como por motores elétricos (instrumentação eletromecânica). A escolha, por parte do profissional, de um desses sistemas ou da forma de acioná-los depende, fundamentalmente, do domínio da técnica e dos recursos financeiros existentes.

Assim, muitos estudos têm sido realizados no intuito de esclarecer qual o sistema, tipo de acionamento e técnica de instrumentação rotatória promove maior segurança e benefício tanto ao paciente, como ao profissional (Leonardo \& Leonardo, 2002). 


\section{C - Utilização do laser na Endodontia:}

A aplicação do laser na Odontologia tem aguçado os pesquisadores nas suas várias indicações e contra-indicações na busca do aperfeiçoamento da terapêutica, assim como a melhoria no conforto e da qualidade dos serviços realizados.

Laser é uma abreviação de "Light amplification by stimulation of radiation", ou seja amplificação da luz por emissão estimulada de radiação. Desde a teoria de Einstein (19151916) sobre a emissão estimulada de luz que teve como base à teoria Quântica de Planck (1900), a evolução não parou (homepage FORP-USP).

A primeira emissão estimulada de radiação foi desenvolvida por Maiman (1960), apresentando o primeiro "Maser" (Microwave amplification by stimulated emission of radiation), que foi gerado por meio da excitação de uma barra de rubi.

Coube a Stern \& Sogannaes (1964) a realização do primeiro estudo utilizando o laser na Odontologia. Neste estudo, foi utilizado o laser de rubi, que foi aplicado "in vitro" em tecidos dentais, gerando crateras e fusão de esmalte e dentina, sem contar que foi observada alteração de temperaturas nos tecidos irradiados.

Goldman et al. (1965) foi o pioneiro na aplicação do laser em tecidos dentais "in vivo". O laser utilizado foi o de rubi e o paciente não relatou dor no ato da utilização nem posteriormente a seu uso.

Wolbarst (1984) alertou que devido à existência de água na composição do esmalte e dentina, a energia do laser Er: YAG seria absorvida por essa água, causando sua expansão volumétrica, o que resultaria na ablação. Isto foi confirmado posteriormente por Hibst \& Keller (1989).

Os resultados obtidos por Hibst \& Keller (1989) ao aplicar a radiação laser do Er: YAG pulsado com 2,94 $\mu \mathrm{m}$ em dentina e esmalte mostraram que este tipo de laser foi mais eficiente 
na ablação na dentina do que no esmalte. Tanto o esmalte quanto a dentina são removidos em parte pela vaporização contínua e em parte sob a forma de micro explosões, e os efeitos da temperatura foram pequenos comparados a outros lasers.

Keller \& Hibst (1989) compararam a ação do laser de $\mathrm{CO}_{2}$ e Er: YAG sobre a estrutura da dentina e concluíram que o laser de $\mathrm{CO}_{2}$ causava fusão, carbonização e fissuras. Esses achados não eram observados quando se usava o laser de Er: YAG. Este último foi capaz de remover partículas teciduais por meio de micro explosões e vaporização, pelo processo chamado ablação.

O laser Er: YAG, em especial, tem atraído a atenção devido à sua facilidade de cortar tecidos duros com alterações térmicas extremamente pequenas (Keller \& Hibst, 1989; Visuri et al., 1996).

Ao comparar, por meio de microscopia eletrônica de varredura, os efeitos do laser de Er: YAG em superfícies secas e com uma fina névoa de água, Burkes et al. (1992), concluíram que este laser usado em superfícies úmidas remove esmalte e dentina sem produzir significantes alterações na temperatura pulpar, ao contrário dos lasers de rubi, $\mathrm{CO}_{2}$ e $\mathrm{Nd}$ : YAG, que induziram a severas alterações pulpares devido às injúrias térmicas.

Zakariasen (1993), após seus estudos, concluiu que o uso de laser em procedimentos endodônticos requer elevada liberação de energia, resultando em dano e trauma às estruturas irradiadas, fazendo-se então necessária a prévia seleção do comprimento de onda e conhecimento das interações entre o laser e os tecidos dentais.

Wigdor et al. (1993) compararam a eficiência dos lasers Er: YAG, $\mathrm{CO}_{2}$ e Nd: YAG na atuação sobre a dentina "in vitro" e evidenciaram que o Er: YAG causou os menores efeitos negativos entre os lasers estudados, e a área imediatamente adjacente mostrou-se lisa, sem ondulações e com a presença de túbulos dentinários visíveis. Os outros tipos de laser, ao 
contrário, causaram maior desrupção da dentina não apresentando túbulos dentinários visíveis, e com nível significante de fraturas. Essa eficiência do laser de Er: YAG foi confirmada por Takahashi et al. (1996) ao observar que após sua irradiação, a maior parte da camada de "débris" e "smear" havia sido removida e os túbulos dentinários ficaram visíveis.

Fegan \& Steiman (1995) relataram a capacidade de desinfecção do laser Nd: YAG e de outras técnicas tais como instrumentação manual, instrumentação ultra-sônica, todas associadas com água estéril ou hipoclorito de sódio aplicado ao canal radicular "in vitro". Todos os casos em que o hipoclorito de sódio foi utilizado houve ausência de crescimento bacteriano. De acordo com os autores, o efeito do laser na desinfecção de canais radiculares necessita ainda de maiores estudos.

Zezell et al. (1996) avaliaram um protótipo de um aparelho laser Er: Tm: Ho: LiYF4 (Ho: YLF), que emite comprimento de onda de 2,065 micrometros e largura de pulso de 250 micro-segundos, sobre a elevação de temperatura no interior da câmara pulpar durante o preparo de cavidades. Com os parâmetros de $500 \mathrm{~mJ}, 5 \mathrm{~Hz}$ e $2,079 \mathrm{~J} / \mathrm{cm}^{2}$, o aumento da temperatura intrapulpar era de no máximo de $3,8^{\circ} \mathrm{C}$. Os resultados sugerem a possibilidade deste laser ser utilizado tanto no preparo cavitário como em preparo de canais radiculares.

Cobb et al. (1997) compararam "in vitro" as alterações ocorridas nas paredes dentinárias dos canais radiculares tratados com laser Er: YAG e refrigeração de ar/água, e com os lasers de $\mathrm{CO}_{2}$ e Nd: YAG, utilizados com e sem refrigeração. As amostras tratadas com laser de $\mathrm{CO}_{2}$ foram submetidas às densidades de energia que variaram de 100 até $400 \mathrm{~J} / \mathrm{cm}^{2}$, com laser de Nd: YAG de 286 até $1857 \mathrm{~J} / \mathrm{cm}^{2}$ e o de Er: YAG com variação de 20 até $120 \mathrm{~J} / \mathrm{cm}^{2}$. Foram utilizados 42 dentes, distribuídos em 7 grupos experimentais, dos quais o grupo controle não foi irradiado. Os autores concluíram neste experimento que as alterações na estrutura das paredes dentinárias dos canais radiculares causadas pelo laser de $\mathrm{CO}_{2}$ e Nd: YAG estavam 
diretamente relacionadas com a densidade de energia e não ao uso de refrigeração. Os lasers induziram alterações de superfície como carbonizações, cavitações, remineralizações, fusões dentinárias e fissuras. Ao contrário, o laser de Er: YAG provocou alterações radiculares superficiais similares ao condicionamento ácido, isto é, removeu "smear" expondo os túbulos dentinários, sem evidência de fusão e carbonização.

Liu et al. (1997) estudaram a profundidade de selamento dos canalículos dentinários em dentes irradiados com laser de Nd: YAG. Para a análise dos resultados os autores utilizaram o microscópio eletrônico de varredura e verificaram que ocorreu fusão e selamento dos túbulos dentinários expostos sem provocar rachaduras na superfície dentinária. Os túbulos dentinários estavam selados, e a permeabilidade e a hipersensibilidade foram reduzidas.

Blum Abadie (1997) avaliaram quatro técnicas de instrumentação quanto à capacidade de limpeza dos canais radiculares. Neste estudo, foram utilizadas cinqüenta raízes palatinas de molares superiores, divididas em cinco grupos, como se segue: I. instrumentação manual (serial preparation), II. preparação com laser (Nd: YAG), III. instrumentação manual associada ao uso do laser, IV. instrumentação manual associada ao uso de instrumento sônico (MM 3000) e V. instrumentação manual associada ao uso de instrumentos sônicos e laser. As paredes dos canais foram avaliadas por meio da microscopia eletrônica de varredura. O grupo $\mathrm{V}$, que utilizou a associação das três diferentes técnicas, foi o que apresentou melhores resultados, com menor presença de "débris" e túbulos dentinários mais abertos. O grupo II não apresentou dilatação do canal, com presença de grande quantidade de "débris". Os grupos I, III e IV não apresentaram diferença estatística significante em relação à limpeza dos canais radiculares.

Tanji et al. (1997) avaliaram o aspecto micro morfológico das paredes do canal radicular irradiadas com o laser Er: YAG em diferentes níveis de energia $\left(8,64 \mathrm{~J} / \mathrm{cm}^{2} ; 11,29 \mathrm{~J} / \mathrm{cm}^{2}\right.$ e 
$14,11 \mathrm{~J} / \mathrm{cm}^{2}$ ). Foram utilizados 35 dentes com canais preparados convencionalmente e, posteriormente, irradiados com laser em diferentes parâmetros de energia. O grupo controle foi tratado com ácido fosfórico a 35\%. Os resultados mostraram que a utilização do parâmetro $14,11 \mathrm{~J} / \mathrm{cm}^{2}$ de energia propiciava maior remoção da "smear", deixando os túbulos dentinários totalmente desobstruídos em toda extensão do canal.

Ebihara et al. (1998) avaliaram, por meio da microscopia eletrônica de varredura, a eficiência de corte e a penetração do corante azul de metileno em superfícies apicectomizadas com laser Er: YAG ou com brocas acionadas em baixa rotação. Em outros grupos, os ápices foram cortados com brocas em baixa rotação e a cavidade retrógrada foi preparada com laser Er: YAG ou ultra-som. Não houve presença da camada de "smear" na superfície preparada com laser Er: YAG, mas nas superfícies preparadas com brocas, a "smear" esteve presente. Não havia "débris", guta-percha ou cimento na cavidade retrógrada preparada com laser de Er: YAG, enquanto observou-se "débris" na cavidade preparada por ultra-som. Também não houve diferença significante entre o uso do laser e o método convencional com respeito à penetração do corante azul de metileno.

Camargo et al. (1998) avaliaram, com o auxílio do microscópio eletrônico de varredura, superfícies apicais cortadas e preparadas para retrobturação com o laser de Er:YAG e outras duas técnicas convencionais. Observaram que o laser produziu cavidades para retrobturação irregulares, mas com túbulos dentinários limpos e sem "smear". Por outro lado, foram observadas cavidades regulares e com os túbulos dentinários fechados e cobertos pela "smear" nas superfícies em que foram utilizados o ENAC e brocas acionadas com baixa rotação.

Matsuoka et al. (1998) investigaram o efeito do laser de Er: YAG na remoção de "débris" principalmente na região apical de 80 dentes unirradiculares inferiores instrumentados pela técnica "Step-Back" com limas tipo K. Para tanto, utilizaram o laser com 
os parâmetros 50, 100 e $150 \mathrm{~mJ}$ com freqüência de $20 \mathrm{~Hz}$. A cinemática da fibra óptica em 50 $\mathrm{mJ}$ foi a de introduzi-la até o comprimento de trabalho e irradiar por 5 segundos, posteriormente 10 segundos em cada parede dos canais radiculares, perfazendo um total de 45 segundos. Para $100 \mathrm{~mJ}$ a fibra foi introduzida no comprimento de trabalho e o laser foi irradiado 3 segundos e a seguir deslocado e aplicado por 5 segundos nas paredes dos canais radiculares, num total de 23 segundos. Para $150 \mathrm{~mJ}$, a fibra foi levada ao comprimento de trabalho e o laser foi irradiado por 1 segundo, posteriormente a fibra foi deslocada e o laser foi aplicado por 2 segundos em cada parede do canal radicular, perfazendo o total de 9 segundos. Os autores afirmaram que o laser foi eficiente na limpeza do ápice radicular e, o grupo do laser com $150 \mathrm{~mJ}$ promoveu maior limpeza das paredes dos canais radiculares.

Takeda, F.H. et al. (1998), estudando a eficiência do laser de Er: YAG na limpeza das paredes dos canais radiculares em 36 incisivos inferiores extraídos. Concluíram que este laser é eficiente na remoção de "débris" e "smear". Após a aplicação, a dentina apresentava-se livre de "débris" e "smear", mostrando túbulos dentinários abertos. Observaram também, as alterações morfológicas nas paredes dos canais radiculares após a instrumentação e irrigação. Concomitantemente, avaliaram a eficiência dos procedimentos de limpeza convencionais e a do laser de Er: YAG na remoção de resíduos e "smear" das paredes dos canais radiculares por meio da microscopia eletrônica de varredura. Os autores afirmam que a radiação laser pode ser usada nos procedimentos endodônticos com resultados promissores e a aplicação deste tipo de laser parece ser eficiente na limpeza dos canais radiculares preparados.

Takeda et al. (1998a) avaliaram os efeitos de três tipos de laser (Argônio, Nd: YAG e Er: YAG) na remoção da "smear" das paredes dos canais radiculares. A fibra óptica foi posicionada no comprimento de trabalho do canal previamente instrumentado e a região apical foi irradiada por 3 segundos. O laser foi ativado durante a retirada da fibra com 4 exposições 
de 15 segundos de duração, perfazendo o total de 63 segundos. Durante o uso dos lasers, o spray de água foi utilizado. Os três tipos de laser demonstraram capacidade em remover a “smear". Porém o laser Er: YAG foi o mais eficiente.

Takeda et al. (1998b) estudaram o efeito do laser Er: YAG com 100mJ e 10Hz na limpeza de canais radiculares. A fibra óptica foi posicionada na região apical e a irradiação foi de 3 segundos e, a seguir, a fibra foi deslocada para região cervical e o laser foi ativado por mais três segundos em um grupo. No outro grupo, o laser foi ativado com 5 segundos de duração em cada posição. Os resultados demonstraram que o uso da irradiação por 5 segundos em cada terço promoveu maior limpeza dos canais radiculares.

Takeda et al. (1998c) avaliaram "in vitro" a eficiência do laser de Er: YAG na limpeza das paredes dos canais radiculares preparados, e observaram que elas se apresentavam livres de "débris" e "smear", e os orifícios dos túbulos dentinários encontravam-se abertos tanto nos canais tratados com $1 \mathrm{~W}$ de potência quanto nos tratados com $2 \mathrm{~W}$.

Zhang et al. (1998) avaliaram, por meio da microscopia eletrônica de varredura, a ação do laser de $\mathrm{Nd}$ : YAG sobre as paredes de dentina dos canais radiculares de 40 dentes unirradiculares inferiores extraídos. Os dentes foram divididos em 4 grupos, no grupo 1 não foi utilizado o laser, servindo como grupo controle, no 2, os espécimes foram irradiados por quatro vezes de 10 segundo, perfazendo um total de 40 segundos por canal, no grupo 3 os canais radiculares receberam uma pintura com tinta preta e o laser foi irradiado da mesma forma que o grupo anterior e no grupo 4, os espécimes foram tratados com $\mathrm{Ag}\left(\mathrm{NH}_{3}\right) 2 \mathrm{~F}$ a $38 \%$ e irradiados com o laser da mesma maneira que o grupo anterior. Os autores constataram que no grupo onde apenas foi irradiado com o laser, o resultado não foi satisfatório e, que o uso da tinta preta auxiliava com mais eficiência na ação do laser de Nd: YAG. 
Harashima et al. (1998) avaliaram a capacidade do laser de Argônio em remover "débris" e "smear" das paredes dos canais radiculares. Doze molares superiores com três canais radiculares foram instrumentados e divididos em dois grupos. O primeiro grupo foi controle (não irradiado com laser), o segundo grupo foi irradiado com laser de Argônio (1 W, 0.05 pulsos por segundo e $15 \mathrm{~Hz}$ ). Após o preparo do canal radicular e irradiação com laser, as coroas foram removidas, as raízes seccionadas longitudinalmente e posteriormente foram avaliadas por meio de microscopia eletrônica de varredura quanto à limpeza das paredes do canal. Na maioria dos casos, o grupo controle apresentava "débris" cobrindo as paredes dos canais radiculares e obstruindo os túbulos. Apenas 1 dos 18 espécimes estava livre de “débris". No grupo irradiado com laser, as paredes dos canais apresentavam-se livres de "débris". Os resultados evidenciaram diferenças estatisticamente significantes entre os dois grupos $(\mathrm{p}<0,001)$, comprovando a eficiência da irradiação a laser sobre canais instrumentados.

Cecchini et al. (1998) avaliaram, “in vitro", os efeitos térmicos da aplicação intracanal do laser Er:YAG e as alterações morfológicas promovidas pelo mesmo na superfície do canal radicular por meio de par termoelétrico e microscópio eletrônico de varredura, respectivamente. Os parâmetros utilizados foram: freqüência $10 \mathrm{~Hz}$ e energia 40 a $80 \mathrm{~mJ}$ na ponta da fibra óptica (output). Os resultados demonstraram aumento de 2 a $4^{\circ} \mathrm{C}$ na temperatura da superfície radicular, e paredes dentinárias sem presença da "smear", o que possibilitou aos autores o estabelecimento de parâmetros energéticos clinicamente seguros para a utilização deste laser no interior dos canais radiculares.

Takeda et al (1999) realizaram um estudo comparando a capacidade de remoção da "smear" de três soluções irrigantes e dois tipos de laser. Após instrumentação com limas manuais e hipoclorito de sódio a 5,25\% alternado com peróxido de hidrogênio a 3\%, os canais sofreram irrigação final com EDTA a $17 \%$, ácido fosfórico a $6 \%$ e ácido cítrico a $6 \%$ ou 
foram irradiados com laser $\mathrm{CO}_{2}$ ou Er: YAG. Os dentes submetidos à irrigação final com ácido fosfórico a $6 \%$ e ácido cítrico a $6 \%$ apresentaram menores quantidade da camada de "smear" do que aqueles irrigados com EDTA. Os dentes irradiados com laser $\mathrm{CO}_{2}$ apresentaram-se com paredes dentinárias limpas, com ausência ou fusão e cristalização da camada de "smear". O laser de Er: YAG foi capaz de remover a "smear" promovendo túbulos dentinários abertos. Os autores concluíram que a irradiação com o laser de Er: YAG foi o método mais eficiente na eliminação da "smear" do canal radicular.

Pécora et al (1999) estudaram "in vitro" a ação do laser de Er: YAG após a instrumentação com água e com o hipoclorito de sódio sobre a permeabilidade dentinária. Para o estudo da permeabilidade dentinária, foi utilizado o método histoquímico, ou seja, íons cobre foram revelados pelo ácido rubiânico. Os resultados evidenciaram que os canais instrumentados com água e irradiados com laser de Er: YAG apresentaram maior permeabilidade dentinária.

Pécora et al. (2000a) determinaram o aumento de temperatura na superfície externa das raízes dos dentes após a utilização da irradiação do laser de Er: YAG com e sem irrigação em canais radiculares previamente instrumentados. Os resultados mostraram que, na presença de irrigação, o aumento de temperatura nos dentes irradiados com o laser foi menor que os irradiados com laser sem irrigação.

Brugnera (2001) avaliou, por meio da reação histoquímica utilizando sulfato de cobre a 10 \% e solução alcoólica de ácido rubiânico a 1 \%, a ação dos lasers de Er: YAG e Nd: YAG sobre a permeabilidade da dentina das paredes dos canais radiculares instrumentados com a utilização da água destilada deionizada e solução de hipoclorito de sódio a $1 \%$ como soluções irrigantes. $\mathrm{O}$ autor concluiu que os melhores resultados de permeabilidade foram alcançados com o grupo onde houve associação do laser de Er: YAG à água destilada e deionizada. Os 
menores valores apresentados foram os do grupo da associação da aplicação de laser de Nd: YAG com a solução de hipoclorito de sódio a 1 \% e o da água destilada deionizada.

Pícoli (2001) estudou "in vitro" o efeito da aplicação do laser de Er: YAG e da solução de EDTAC na superfície dentinária sobre a adesividade de diferentes cimentos endodônticos contendo hidróxido de cálcio. Os resultados mostraram diferença estatisticamente significante $(\mathrm{p}<0,01)$ para os cimentos testados e os diferentes tratamentos aplicados à superfície dentinária. A aplicação do laser de Er: YAG e da solução de EDTAC não resultaram em aumento significativo da capacidade adesiva dos cimentos $\operatorname{CRCS}^{\circledR}$ e Sealapex ${ }^{\circledR}$. Entretanto, tanto a aplicação do laser de Er: YAG quanto a solução de EDTAC foram eficientes no aumento da adesão dos cimentos Sealer $26^{\circledR}$ e Apexit ${ }^{\circledR}$. A aplicação do laser de Er: YAG só foi significativamente superior à solução de EDTAC em propiciar aumento da adesividade do cimento Sealer $26^{\circledR}$ à dentina.

Ribeiro (2001), avaliou a permeabilidade dentinária dos canais radiculares instrumentados com diferentes soluções irrigantes, tais como água destilada e deionizada, hipoclorito de sódio a $1 \%$, lauril dietilenoglicol éter sulfato de sódio a $0,1 \%$, EDTA a $15 \%$ e ácido cítrico a $10 \%$ associados ou não ao uso do laser de Er: YAG. O autor concluiu que a utilização da água destilada deionizada associada ao laser de Er: YAG e o uso isolado da solução de hipoclorito de sódio a $1 \%$ promoveram os maiores valores de permeabilidade dentinária radicular em relação aos demais tratamentos e de modo estatisticamente semelhantes entre si. A menor permeabilidade foi constatada no grupo da água destilada deionizada e na solução de lauril dietilenoglicol éter sulfato de sódio a $0,1 \%$.

Barbizam (2001) avaliou, "in vitro", a infiltração marginal apical em canais radiculares obturados com três modos de tratamento das paredes dos canais radiculares durante a instrumentação e utilização de dois tipos de cimentos obturadores. Para evidenciar a 
infiltração, foi utilizada a tinta nanquim. Para este estudo, sessenta e cinco incisivos centrais superiores de estoque foram necessários. Os dentes foram divididos em três grupos contendo vinte dentes cada. O grupo 1 , os dentes foram preparados da forma convencional apenas com hipoclorito de sódio e foram obturados dez canais com cimento Endo Fill ${ }^{\circledR}$ e dez com cimento Top Seal ${ }^{\circledR}$, no grupo 2, os canais receberam uma irrigação final com 5ml de EDTA a 17 \% e a seguir obturados como o grupo 1 e no grupo 3 , os canais receberam a aplicação adicional de laser de Er: YAG com os parâmetros de 140 mJ/15Hz, 42 J, e depois foram obturados como no grupo 1. Em seguida, os dentes foram selados com Cimpat $^{\circledR}$ e armazenados a $37^{\circ} \mathrm{C}$ e umidade relativa de $95 \%$ durante dois dias. Findo este tempo, foram impermeabilizados com duas camadas de cianoacrilato e imersos em tinta nanquim por uma semana. Os dentes sofreram então processo de diafanização em salicilato de metila, e a infiltração apical foi mensurada. Os resultados evidenciaram que os dentes obturados com o cimento Top Seal ${ }^{\circledR}$ apresentaram os menores níveis de infiltração $(\mathrm{p}<0,01)$. Os dentes preparados com hipoclorito de sódio a $1 \%$ irradiados ou não com laser de Er: YAG apresentaram os mesmos níveis de infiltração marginal apical, menores que os níveis apresentados por aqueles irrigados com hipoclorito de sódio a 1\% e irrigação final com EDTA a 17 \%.

Castro (2002) avaliou o efeito dos raios laser de Er: YAG, $\mathrm{CO}_{2}$ e Nd: YAG sobre a permeabilidade dentinária apical após apicectomia. Para tanto, foram utilizados quarenta e quatro dentes unirradiculares, que foram instrumentados pela técnica "Step-Back", irrigados com solução de hipoclorito de sódio e obturados com cimento obturador Sealer $26^{\circledR}$ pela técnica da condensação lateral. As amostras foram divididas em quatro grupos aleatoriamente de onze dentes cada. As raízes foram seccionadas pelos seguintes sistemas: G1- broca diamantada cônica 4138 em alta rotação, G2 - laser de Er: YAG nos parâmetros de 15 Hz e 
250 mJ, G3 - laser de Er: YAG com o mesmo parâmetro do grupo anterior e posterior aplicação do laser de Nd: YAG (10 Hz, 100 mJ e 1W) na superfície seccionada, e G4 - laser de Er: YAG com os mesmos parâmetros do grupo anterior e posteriormente aplicação do laser $\mathrm{CO}_{2}(5 \mathrm{~W}, 10$ segundos on e 20 segundos off, com ponta 14830) na superfície seccionada. A evidenciação da infiltração foi obtida por meio da solução corante azul de metileno 0,5 \% por sete dias. Os resultados permitiram concluir que todos os sistemas de corte permitiram infiltração do corante com diferença estatística ao nível de $1 \%$, em ordem crescente: Er: YAG (G2), broca (G1), e, em conjunto, Er: YAG + $\mathrm{CO}_{2}(\mathrm{G} 4)$ e Er: YAG + Nd: YAG (G3). Com base nestes resultados, o autor afirma que o corte efetuado com laser de Er: YAG proporcionou os menores valores de infiltração do corante, mostrando sua viabilidade de uso clínico para a realização de apicectomias.

Marchesan (2002) avaliou 30 raízes palatinas de molares superiores por meio da microscopia óptica após a instrumentação rotatória com o Sistema ProFile ${ }^{\circledR} .04$ isolado e/ou associado à irradiação laser de Er: YAG, com diferentes parâmetros $(15 \mathrm{~Hz}, 300$ pulses, 42 J, $140 \mathrm{~mJ}$ input, $61 \mathrm{~mJ}$ output e $140 \mathrm{~mJ}$ input e $51 \mathrm{~mJ}$ output). Os resultados mostraram que nenhuma das técnicas empregadas promoveu total limpeza do canal radicular sem diferença estatística entre si. O terço médio apresentou-se mais limpo do que o terço apical em todas as técnicas empregadas, e a aplicação do laser de Er: YAG, com diferentes energias (51 mJ e 61 mJ output), não apresentou diferença estatisticamente significante quanto à capacidade de limpeza.

Guerisoli (2002), por meio da microscopia eletrônica de varredura, avaliou a remoção da "smear" dos canais radiculares de vinte e cinco incisivos inferiores após aplicação de diferentes agentes quelantes e do laser de Er: YAG. As soluções quelantes utilizadas foram EDTAC, CDTA, EGTA e, quanto ao laser, o parâmetro de 140 mJ "in put" (51 “out put”), 15 
Hz, 300 pps. Os resultados revelaram que o EDTAC foi capaz de eliminar a "smear" com maior eficiência, enquanto a solução de hipoclorito de sódio a $1 \%$ mostrou-se impotente na limpeza do canal radicular. As soluções EGTA e CDTA juntamente com o laser de Er: YAG ocuparam uma posição intermediária quanto à capacidade de remoção da "smear". E não houve diferença estatística entre os terços.

Kimura et al. (2002) mediram a temperatura da superfície dos canais radiculares durante o preparo com laser de Er: YAG e avaliaram o efeito térmico na região periodontal. Para este estudo, foram utilizados 20 dentes unirradiculares humanos extraídos, que foram divididos em 2 grupos de 10 dentes cada. Os dentes foram irradiados com laser de Er: YAG nos parâmetros de $2 \mathrm{~Hz}$ e 136 a 184 ou 170 a $230 \mathrm{~mJ} /$ pulso por 1 minuto com refrigeração a água. A temperatura da superfície do canal foi monitorada usando um termo-par ao longo do procedimento. Os dentes foram seccionados longitudinalmente e observados pelo esterioscópio e pelo microscópio eletrônica de varredura. A temperatura superficial do canal aumentou menos que $6^{\circ} \mathrm{C}$ na região apical e menos que $3^{\circ} \mathrm{C}$ na área central do dente. A avaliação morfológica revelou ausência de carbonização e derretimento da dentina. Esses resultados sugerem que o efeito térmico no tecido periodontal durante o preparo com laser de Er: YAG no parâmetro ate $230 \mathrm{~mJ}$ por minuto foi mínimo.

Silva (2003) avaliou "in vitro" à infiltração apical sofrida em dentes submetidos a apicectomia com e sem o uso de laser de Er: YAG e retrobturados com diferentes materiais. Foram utilizados cento e vinte e seis caninos unirradiculares, os quais foram instrumentados pela técnica manual "Crown-Down", irrigados alternadamente com solução de hipoclorito de sódio a $1 \%$ e EDTA a $17 \%$, e obturados com cimento obturador Sealer $26^{\circledR}$ e cones de gutapercha pela técnica da condensação lateral. Metade dos dentes foram apicectomizados por meio do laser de Er: YAG pulsado nos parâmetros de $15 \mathrm{~Hz}$ e 250 mJ, sendo retrobturados 
com o cimento ProRoot ${ }^{\circledR}$ MTA ou Portland, recebendo impermeabilização com cianoacrilato de metila (Super-Bonder ${ }^{\circledR}$ ), adesivo dentinário Prime \& Bond ${ }^{\circledR}$ NT/NRC ou ausência de selamento. A outra metade recebeu corte apical com broca carbide TF $199 \mathrm{Z}$ em alta rotação sob refrigeração e se seguiu a mesma metodologia empregada nos grupos do laser. Posteriormente, os dentes foram imersos em solução de rodamina B a $0,5 \%$, por 7 dias a $37^{\circ} \mathrm{C}$. Os resultados evidenciaram que nenhum dos fatores de variação, tais como a metodologia de corte apical, cimento retrobturador e película seladora, foi capaz de impedir a infiltração do corante. O emprego do laser de Er: YAG na apicectomia apresentou menor infiltração do corante de modo estatisticamente significante $(p<0,05)$ do que o outro grupo. Quanto ao cimento retrobturador, o $\operatorname{ProRot}^{\circledR}$ MTA apresentou menor infiltração de modo estatisticamente significante $(\mathrm{p}<0,01)$ comparado ao outro cimento. $\mathrm{O}$ autor pôde concluir, também, que a não utilização da película promoveu maior infiltração do corante, de modo estatisticamente significante $(\mathrm{p}<0,05)$.

Souza (2003) avaliou a infiltração marginal coronária de canais radiculares obturados com observância nos seguintes fatores: a) utilização da solução de hipoclorito de sódio a 1 \% como auxiliar da instrumentação dos canais e posterior irrigação com EDTA a 17 \% e aplicação do laser de Er: YAG nos parâmetros de $10 \mathrm{~Hz}, 250 \mathrm{~mJ}$ no interior dos canais radiculares previamente à obturação, b) aplicação de película seladora sobre a obturação do canal radicular e paredes da câmara pulpar (Super-Bonder ${ }^{\circledR}$ e adesivo Single Bond ${ }^{\circledR}$ ). Para tanto, foram utilizados 94 dentes caninos humanos de estoque, que foram divididos em 3 grupos de 30 dentes cada, sendo que 4 foram utilizados como controle. Posteriormente à metodologia empregada, as amostras foram restauradas provisoriamente com Coltosol $^{\circledR} \mathrm{e}$ armazenadas a $37^{\circ} \mathrm{C}$ em umidade relativa de $95 \%$ durante uma semana. Percorrido este 
tempo, o material restaurador provisório foi removido e as superfícies externas dos dentes foram impermeabilizadas, com exceção do acesso coronário, com 3 camadas de SuperBonder $^{\circledR}$. Em seguida, os dentes foram imersos em tinta Nanquim pelo período de 90 dias, a $37^{\circ} \mathrm{C}$. Findo esse período, foram diafanizados em salicilato de metila e se realizou, então, a mensuração da infiltração por meio de microscopia. $\mathrm{O}$ autor concluiu que a utilização do EDTA e do laser de Er: YAG reduziram a infiltração marginal coronária de modo estatisticamente semelhante entre si quando comparados aos outros grupos que não receberam esses tratamentos. Também pôde afirmar que a aplicação da película após a obturação dos canais radiculares reduziu a infiltração marginal coronária de modo estatisticamente significante $(p<0,01)$, sendo que a película seladora Super-Bonder ${ }^{\circledR}$ apresentou os melhores resultados que o adesivo Single Bond $^{\circledR}$, de modo estatisticamente significante, na redução da infiltração marginal $(\mathrm{p}<0,01)$.

Moura (2003) estudou "in vitro" a ação antimicrobiana do laser de Er: YAG em canais radiculares infectados. Para tanto, utilizou 36 dentes humanos anteriores de estoque, que foram preparados, esterilizados e inoculados com suspensão contendo os seguintes microorganismos: S. aureus, E. faecalis, P. aeruginosa, B. subtilis e C. Albicans. Após o período de inoculação (28 dias), os dentes foram irrigados com água destilada ou hipoclorito de sódio a 1\% e irradiados com laser em dois diferentes parâmetros: 52 mJ e 110 mJ "output". Após a irradiação, os dentes foram irrigados com água destilada esterilizada e se procederam as coletas com pontas de papel absorvente esterilizadas e incubadas em solução de Letheen Broth por 48 e 72 horas. O autor concluiu que a água destilada e o hipoclorito de sódio a 1\% associados ou não à aplicação do laser de Er: YAG, nos parâmetros de $10 \mathrm{~Hz}, 52$ mJ "output" 
e $10 \mathrm{~Hz}, 110 \mathrm{~mJ}$ "output", mostraram ausência de ação antimicrobiana em canais radiculares infectados com os microorganismos inoculados.

A revisão de literatura enfatiza que o laser de Er: YAG é eficiente na remoção da camada de "smear" e "débris" sem causar aumento agressivo de temperatura, não causando danos às estruturas periodontais. Sendo assim, várias pesquisas ainda são necessárias, na busca de outros parâmetros para sua melhor aplicabilidade, bem como associá-lo, para fins de estudo de viabilidade de aplicação clínica, a outros recursos disponíveis para uso em Endodontia. 



\section{PROPOSIÇÃO}

O objetivo do presente trabalho foi avaliar, por meio da microscopia eletrônica de varredura, a utilização do laser de Er: YAG, aplicado com dois parâmetros diferentes, sobre a remoção da camada de "smear" das paredes dos canais radiculares com achatamento mésiodistal submetidos à instrumentação rotatória. 



\section{Preparo dos dentes}

Neste trabalho, foram utilizados incisivos inferiores unirradiculares humanos de estoque do Laboratório de Pesquisa em Endodontia da FORP-USP, armazenados em solução aquosa de timol a $0,1 \%$ à temperatura de $9^{\circ}$ graus centígrados até o momento de uso.

Os incisivos inferiores foram radiografados no sentido proximal para a escolha dos dentes que apresentassem um único canal, num total de 40 dentes. Realizada a seleção, os dentes foram lavados em água corrente por 48 horas com o objetivo de remover traços da solução de timol (Figura 1). 


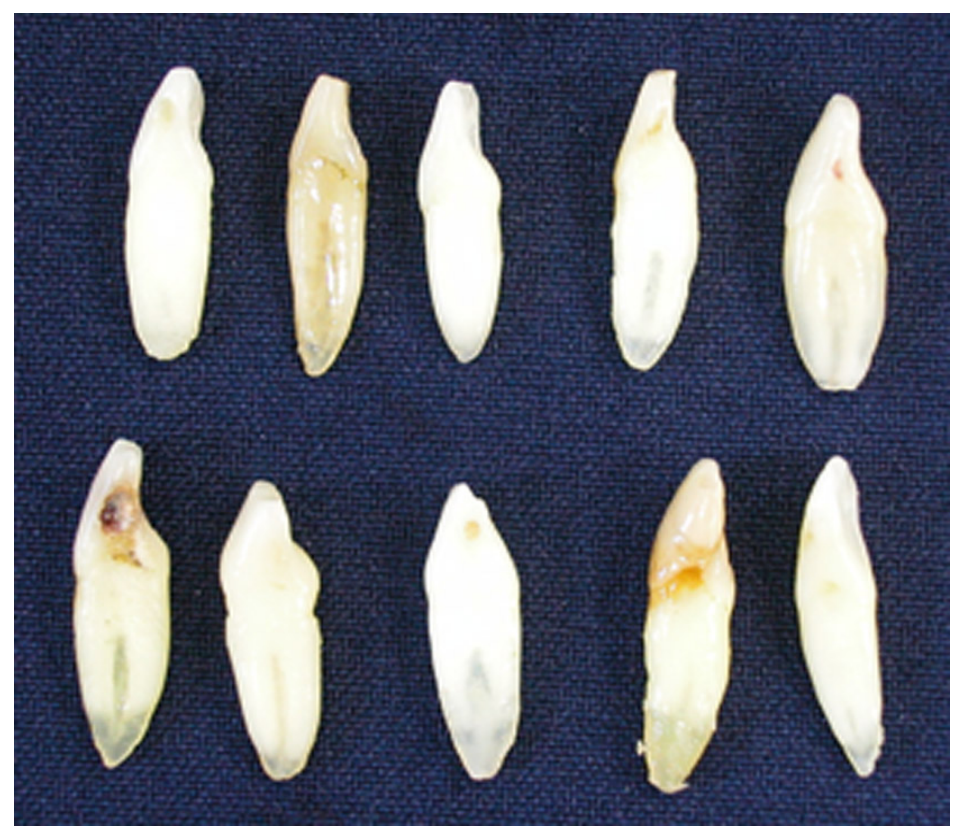

Figura 1 - Incisivos inferiores utilizados no presente experimento

A seguir, as coroas foram seccionadas na junção amelo-cementária com disco de carburundum montados em micro-motor (Dabi-atlante, Brasil).

A determinação do comprimento de trabalho foi realizada com o auxílio de uma lima tipo K \#10 (Maillefer, Ballaigues, Suíça). Quando a lima era visualizada no forame apical, media-se seu comprimento, e, dessa medida, removia-se $1 \mathrm{~mm}$.

Os dentes preparados foram distribuídos aleatoriamente em 4 grupos de dez dentes cada, com os seguintes procedimentos realizados:

Grupo 1: instrumentação rotatória, irrigação com hipoclorito de sódio a 2,5\% e irrigação final com $10 \mathrm{ml}$ de água destilada e deionizada;

Grupo 2: instrumentação rotatória conforme grupo 1 e aplicação de laser Er: YAG com fibra óptica 30/28 e parâmetros de $140 \mathrm{~mJ}$ input, $51 \mathrm{~mJ}$ output e $10 \mathrm{~Hz}$ e irrigação final com $10 \mathrm{ml}$ de água destilada e deionizada; 
Grupo 3: instrumentação rotatória conforme grupo 1 e aplicação de laser Er: YAG com fibra óptica 30/28 e parâmetros de $250 \mathrm{~mJ}$ input, 90 mJ output e $10 \mathrm{~Hz}$ e irrigação final com $10 \mathrm{ml}$ de água destilada e deionizada;

Grupo 4: instrumentação rotatória com irrigação de hipoclorito de sódio a 2,5\% associado a solução de EDTA a 17\% (ØSTBY 1957) e irrigação final com $10 \mathrm{ml}$ de água destilada e deionizada;

\section{Instrumentação Rotatória}

A instrumentação rotatória dos canais radiculares foi realizada com limas de níqueltitânio ( $\mathrm{K}^{3}$ - Keer Sybrom dental especialits (Figura 2), utilizadas de acordo com a seqüência respectiva: 25 taper.06; 25 taper.10; 25 taper.04; 20 taper.06 e 30 taper.04, acionadas por um motor elétrico, (Figura 3) Easy Endo System-Equipamentos Elétricos Ltda-Brasil).

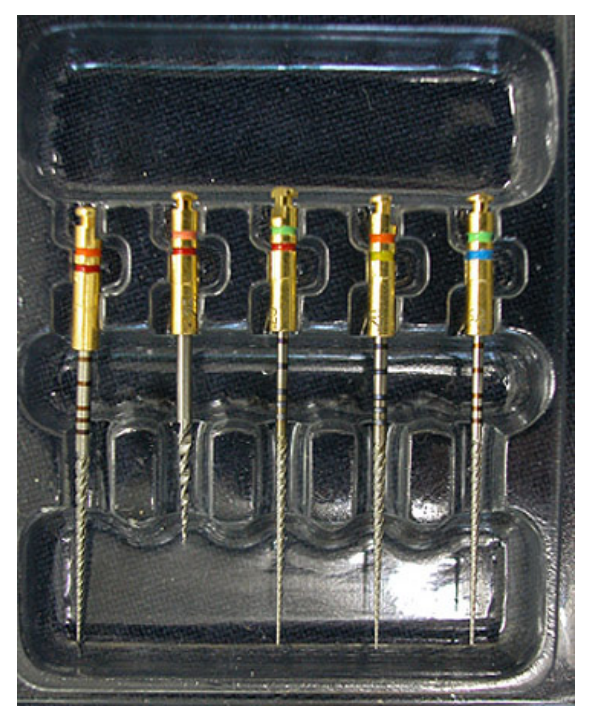

Figura 2 - Limas de níquel-titânio $\left(\mathrm{K}^{3}\right.$ Keer Sybrom dental especialits) 


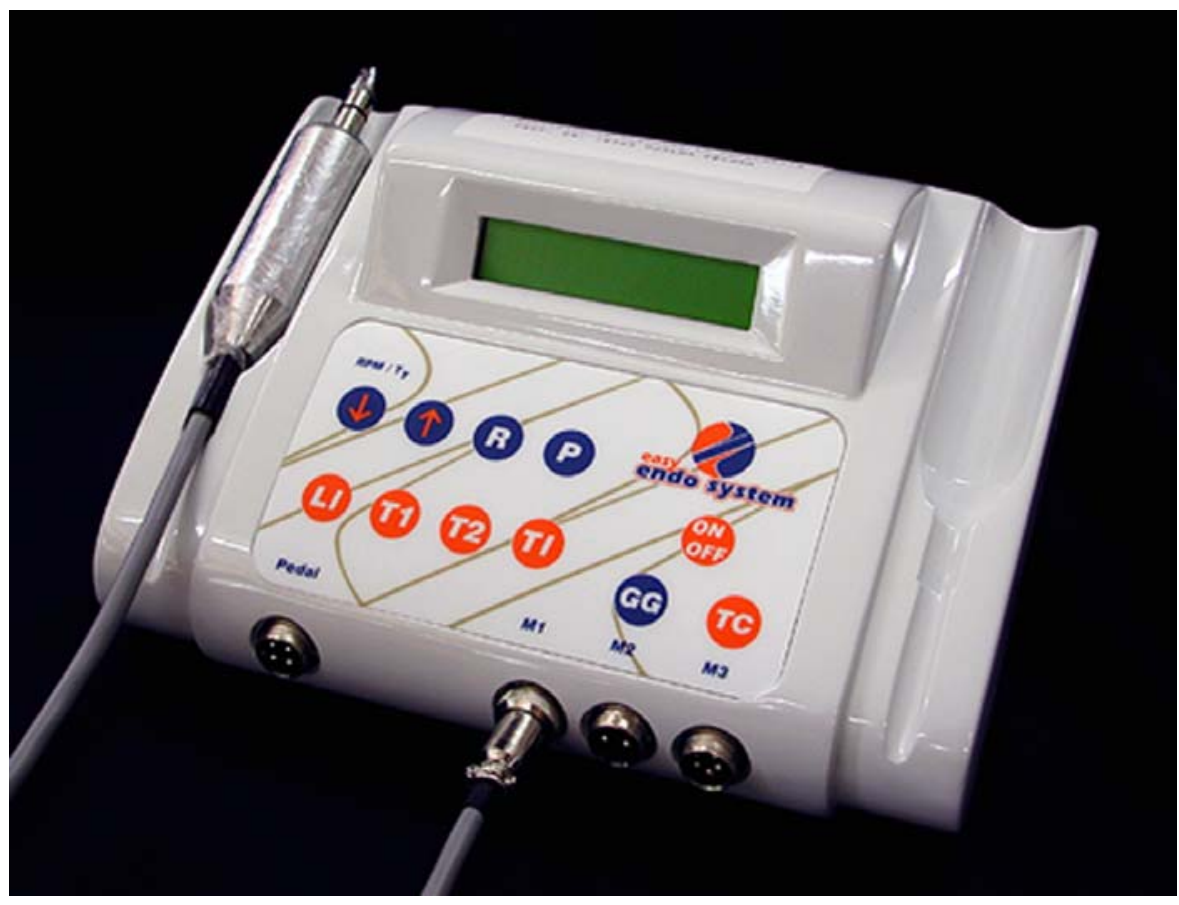

Figura 3 - Motor elétrico (Easy Endo System-Equipamentos Elétricos Ltda-Brasil)

Para a realização da instrumentação, foi utilizada a técnica "Free tip preparation" (PÉCORA et al., 2002), e irrigação do canal com solução de hipoclorito de sódio a 2,5\%, que foi realizada com seringa tipo Luer dotada de um adaptador para agulha de seringa carpule.

A instrumentação foi iniciada com a lima 25 taper.06 até encontrar resistência (como medida de pré-alargamento), seguida da lima 25 taper .10 com o mesmo intuito da lima anterior. O próximo passo foi à utilização das limas 25 taper.04; 20 taper.06 e 25 taper.06 até o comprimento de trabalho pré-estabelecido. Para finalização, foi utilizada a lima 30 taper.04 no mesmo comprimento das anteriores.

Entre cada uso do instrumento rotatório, o canal foi irrigado com $2 \mathrm{ml}$ de solução irrigante, perfazendo um total de $12 \mathrm{ml}$. Findo o preparo do canal radicular, foi realizada irrigação final com $10 \mathrm{ml}$ de água destilada e deionizada. 
Para o grupo 4, a técnica de instrumentação rotatória foi à mesma, com exceção do uso da solução irrigante. O dente recebeu irrigação com $6 \mathrm{ml}$ de solução de hipoclorito de sódio e $6 \mathrm{ml}$ da solução de EDTA a $17 \%$ usados de modo associado entre cada instrumento, perfazendo um total de $12 \mathrm{ml}$. Completada a instrumentação, os canais foram irrigados com 10 $\mathrm{ml}$ de água destilada e deionizada.

\section{Aplicação do laser Er: YAG}

Neste trabalho, foi utilizado o laser Er: YAG (K.E.Y. Laser 1242 da Kavo Dental GmbH, Warthausen, Germany) dotado de uma peça de mão 2055 e fibra óptica 30/28 (Figuras 4 e 5). Esta fibra óptica possui diâmetro de $0,285 \mathrm{~mm}$ e tem fator de transmissão de 0,36 , ou seja, há diferença de energia produzida no aparelho (input) e a energia na ponta da fibra (output). Sendo assim, quando era apresentado no visor o parâmetro de $140 \mathrm{~mJ}$ (input), na ponta da fibra, devido à perda de energia, seu valor output era de $51 \mathrm{~mJ}$. Do mesmo modo quando o aparelho apresentava parâmetro de $250 \mathrm{~mJ}$ no visor (input), seu valor (output) na ponta da fibra era de $90 \mathrm{~mJ}$. 


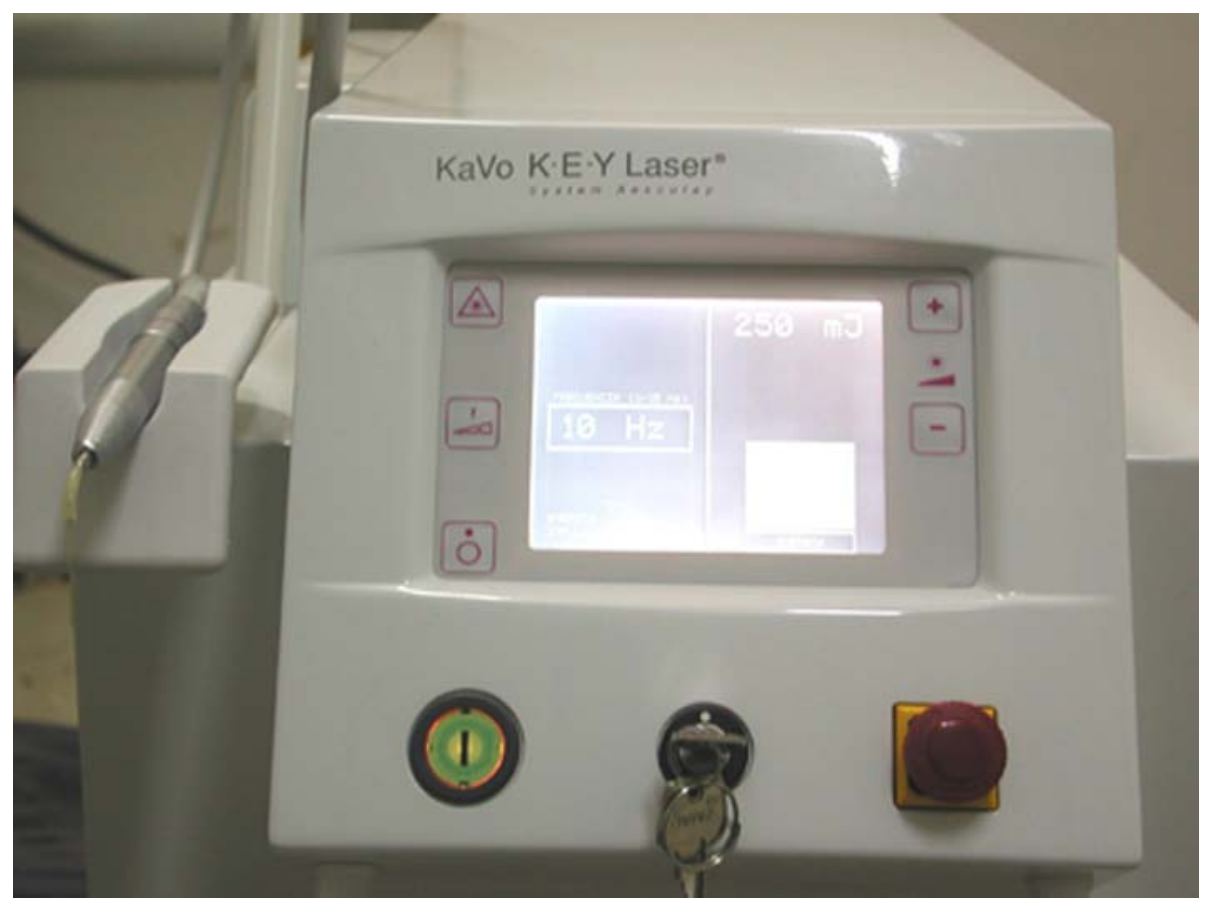

Figura 4 - Aparelho Laser Er: YAG (K.E.Y. Laser 1242 da Kavo Dental GmbH, Warthausen, Germany)

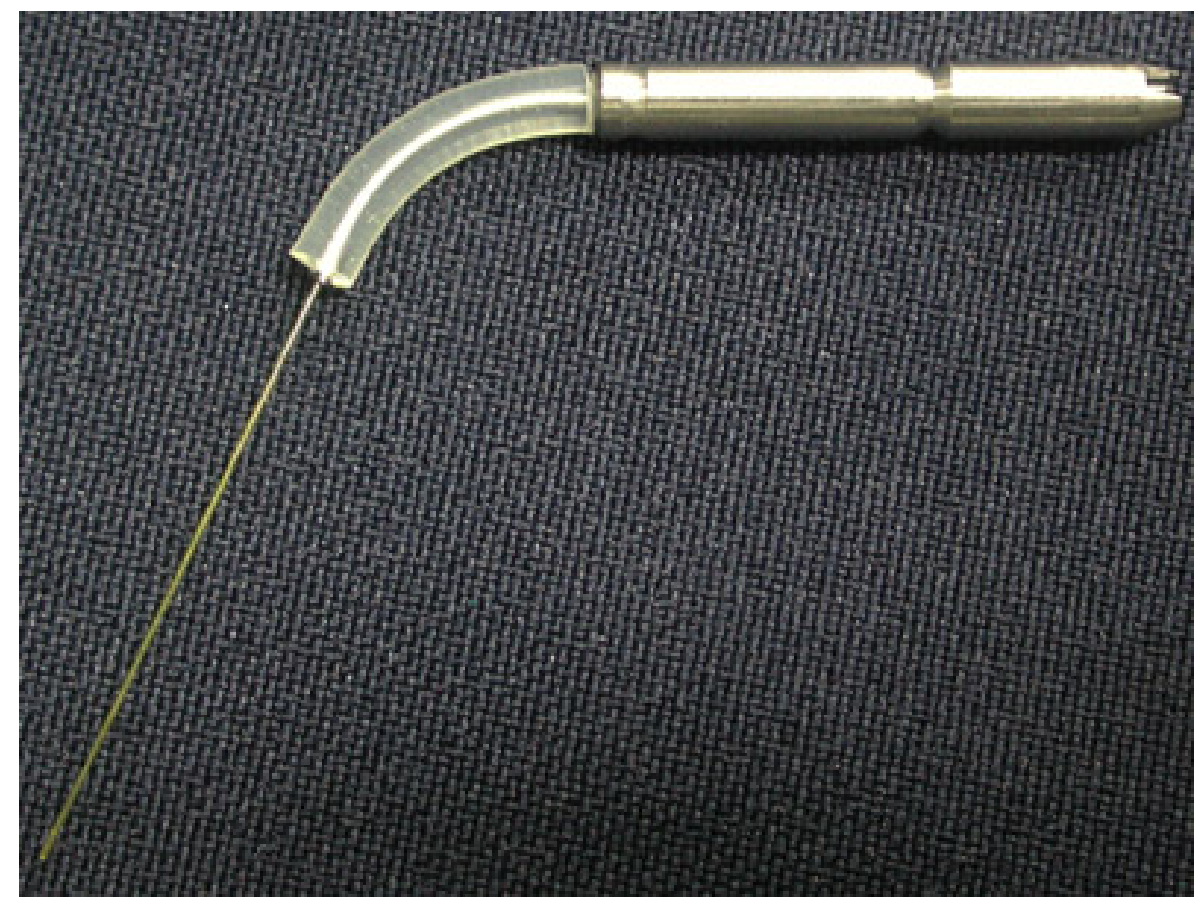

Figura 5 - Detalhe da fibra óptica 30/28 do Laser (Kavo Dental GmbH, Warthausen, Germany) 


\section{Cinemática da fibra óptica durante a irradiação com laser Er: YAG}

A fibra óptica 30/28 foi introduzida no canal radicular até o comprimento de trabalho e, a seguir, o laser foi irradiado. A fibra óptica foi deslocada lentamente com velocidade de 2 $\mathrm{mm} / \mathrm{s}$, perfazendo o total de 7 segundos de aplicação dessa energia até o orifício cervical na câmara pulpar, em contato com a parede vestibular. A seguir, a operação foi repetida de modo que a fibra entrasse em contato com a parede lingual. Esta operação foi realizada por 4 vezes com intervalo de 30 segundos entre cada aplicação. A aplicação do laser foi alternada, ou seja, primeiro em contato com a parede vestibular, depois com a parede lingual. Durante cada aplicação do laser, o canal permanecia repleto com água destilada e deionizada.

Após os preparos, os dentes foram colocados em recipiente de plástico que continha em seu interior gaze umedecida com água destilada e deionizada como medida de armazenagem dos dentes até seu posterior preparo para microscopia eletrônica de varredura.

\section{Preparo dos dentes para microscopia eletrônica de varredura}

Após o preparo dos grupos, realizaram-se canaletas nas raízes por meio de um disco diamantado, e em seguida estas foram clivadas no sentido longitudinal e processadas para serem examinadas ao microscópio eletrônico de varredura. Cumpre salientar que, durante o preparo das canaletas, a abertura do canal radicular foi protegida com Blue Tac (Leicester, UK) a fim de evitar contaminação do canal radicular com pó de dentina.

A seguir, as amostras foram imersas em glutaraldeído a 2,5\% para fixação dos tecidos. Em seguida, passaram por bateria ascendente de álcool de $30,50,70,96^{\circ} \mathrm{Gl}$ por vinte minutos 
em cada e por fim dois banhos de uma hora cada em álcool absoluto (MERCHE, Alemanha), para desidratação dos espécimes. Findo o processo de desidratação, os espécimes foram submetidos a um secador de ponto crítico. Esse aparelho remove todos os traços de água e álcool remanescentes do processo anterior por meio de aplicação de gás $\mathrm{CO}_{2}$, promovendo o seu resfriamento até cerca de $0^{\circ} \mathrm{C}$. Posteriormente, abriu-se lentamente a válvula de admissão de $\mathrm{CO}_{2}$ líquido, até o preenchimento da câmara em mistura com $\mathrm{CO}_{2}$ gasoso. Quando não mais se detectou a presença de álcool em mistura com $\mathrm{CO}_{2}$ liberado, fechou-se a válvula de saída de $\mathrm{CO}_{2}$ puro. Então, fechou-se a válvula de admissão. A amostra foi mantida nas condições ligeiramente acima do ponto crítico (em torno de $32^{\circ} \mathrm{C}$ e 1.100 psi) por 4 minutos. Posteriormente, promoveu-se a descompressão lenta da câmara, abrindo-se a válvula de saída de $\mathrm{CO}_{2}$ (estado gasoso). Quando a pressão da câmara atingiu o valor zero psi, abriu-se a câmara e retirou-se a amostra seca em condições de ser montada.

Os espécimes foram montados sobre estruturas cilíndricas de aproximadamente $10 \mathrm{~mm}$ de diâmetro por $10 \mathrm{~mm}$ de altura. A amostra foi fixada sobre o cilindro (Figura 6), utilizandose fita adesiva de dupla face de material condutivo-(cobre ou alumínio). 


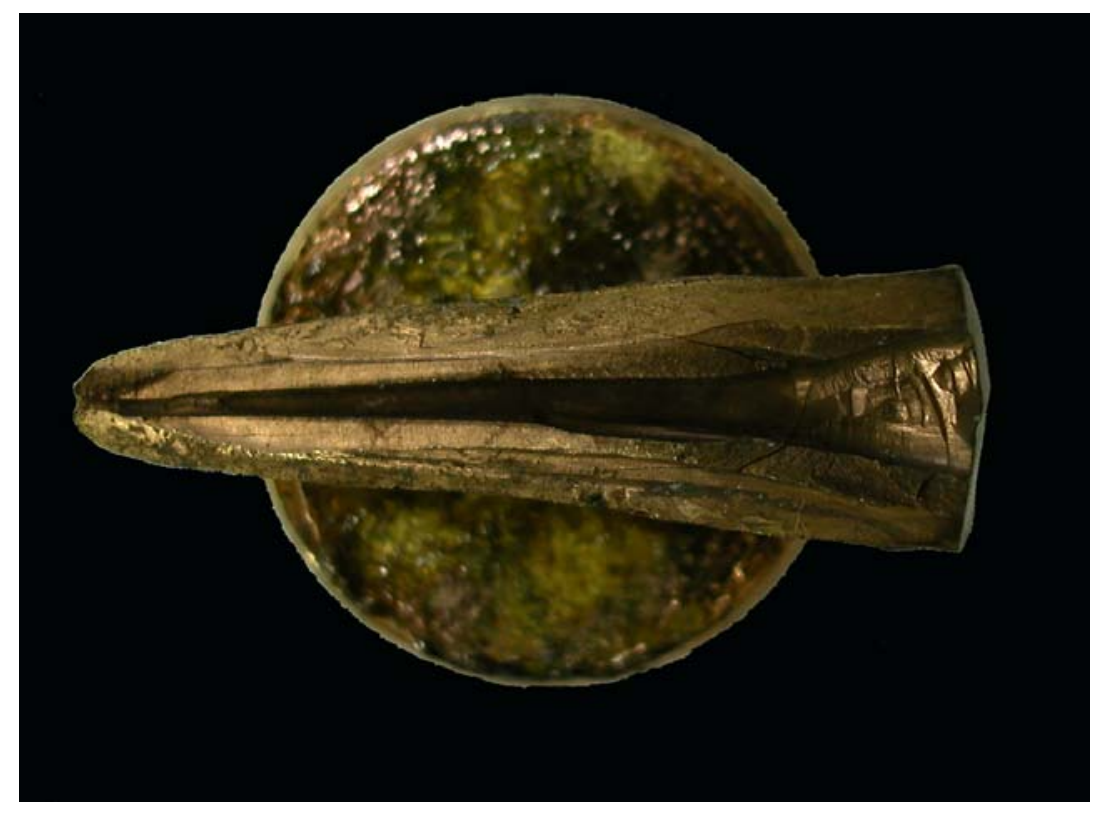

Figura 6 - Hemissecção da raiz fixada em um "stub" de alumínio por meio de adesivo condutor

Em seguida, foi realizada a metalização com uma fina camada (cerca de $30 \mathrm{~nm}$ ) de ouro ou liga de ouro e paládio sob os espécimes em um aparelho de marca JEOL, modelo JFC 1100 de procedência Japonesa (Figura 7).

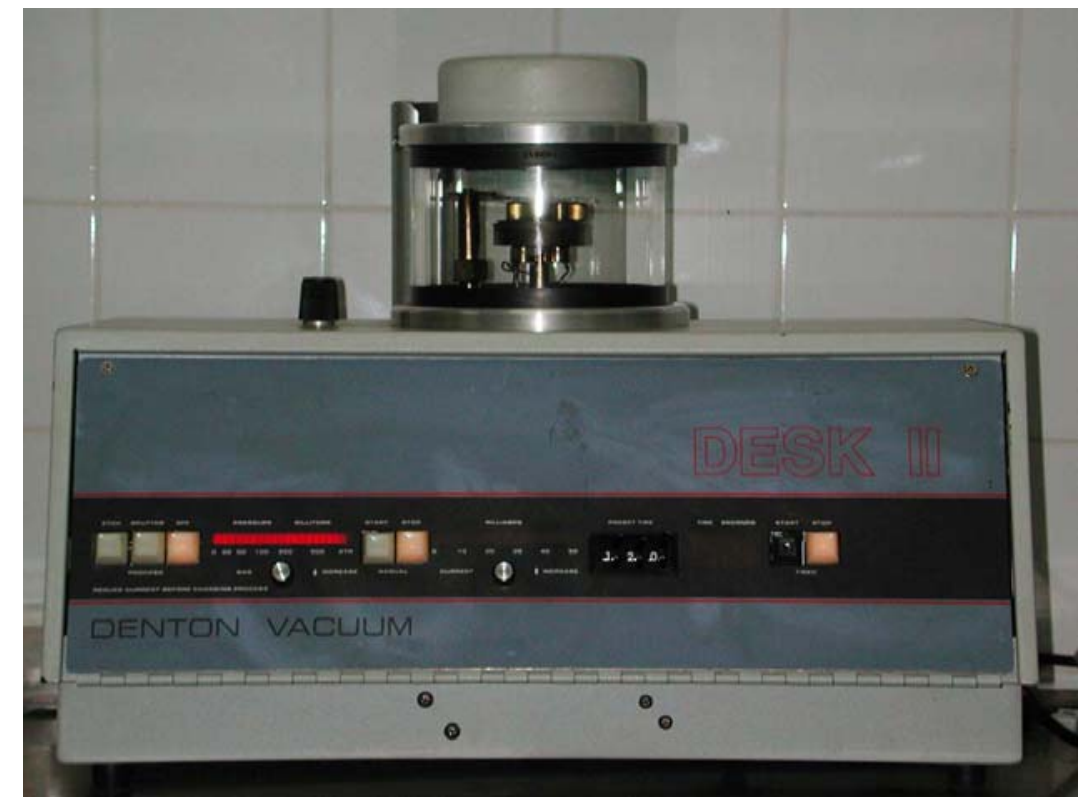

Figura 7 - Metalizador (JEOL, modelo JFC 1100) 
Posteriormente, os dentes foram levados ao microscópio eletrônico de varredura da marca JEOL, modelo JSM 25SII (Japão), instalado no Departamento de Patologia da Faculdade de Veterinária da UNESP de Jaboticabal/SP (Figura 8).

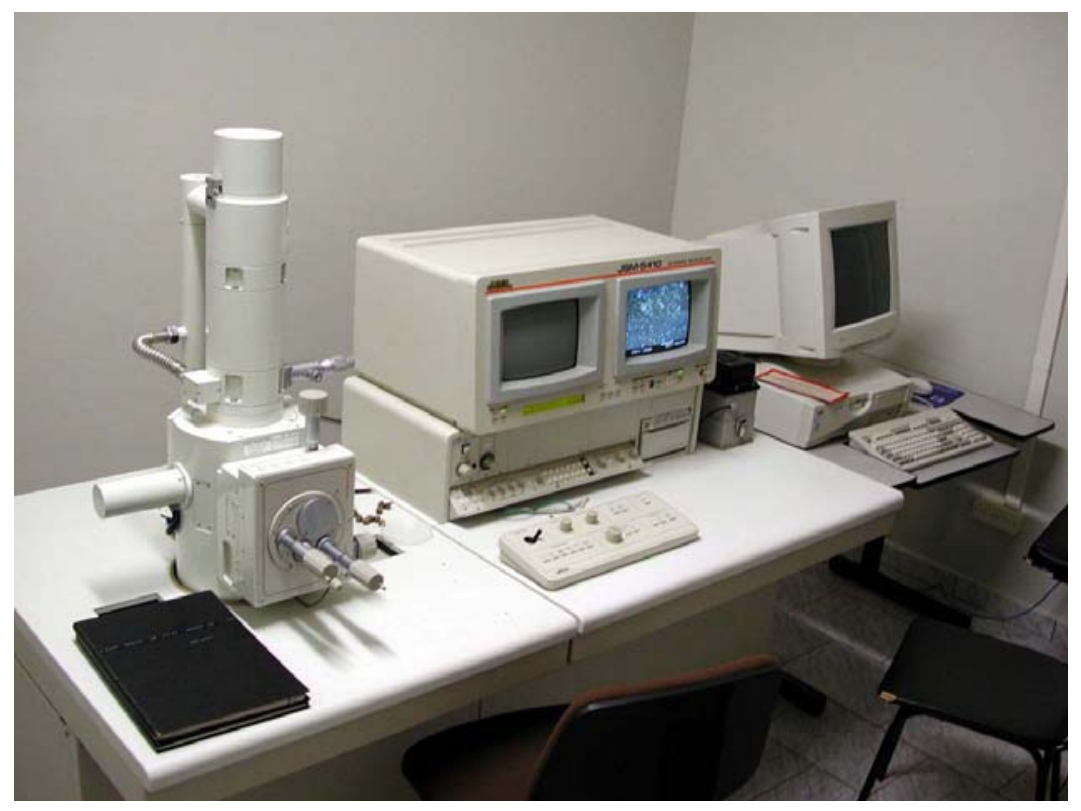

Figura 8 - Microscópio eletrônico de varredura (JEOL, modelo JSM 25SII, Japão)

Foram realizadas fotomicrografias das áreas mais representativas dos terços médio e apical, que foram avaliadas por três examinadores diferentes, com grau mínimo de Mestre, observando a quantidade da "smear" presente nas amostras em relação a três padrões fixos que o programa oferecia, ou seja, os examinadores, sem o prévio conhecimento de qual dos grupos estavam avaliando, atribuíram escores de 1 a 4 às fotomicrografias. Os escores variavam de acordo com a quantidade da "smear" observada, ou seja, 1 (quantidade insignificante da "smear") a 4 (obliteração total dos túbulos dentinários por "smear"), em números absolutos. 


\section{Desenvolvimento do software "Fotoscore"}

No intuito de automatizar o processo de avaliação das fotomicrografias e registro dos resultados de acordo com os diferentes examinadores, foi utilizado um software em ambiente Windows desenvolvido por Guerisoli (2002). Este programa utiliza, como base um banco de dados no formato Access modificado por código em linguagem VBA (Visual Basic for Applications), e é denominado de Fotoscore, o qual apresenta ao avaliador a imagem que deverá ser analisada em comparação a três padrões pré-estabelecidos, situando a foto analisada numa posição intermediária entre esses padrões. O programa registra o escore atribuído pelo avaliador e, após o término do processo, emite um relatório contendo todos os dados. Faz-se necessário salientar que não havia meio, por parte dos avaliadores, de saber qual grupo experimental estavam observando. A Figura 9 apresenta uma reprodução da interface gráfica do programa.

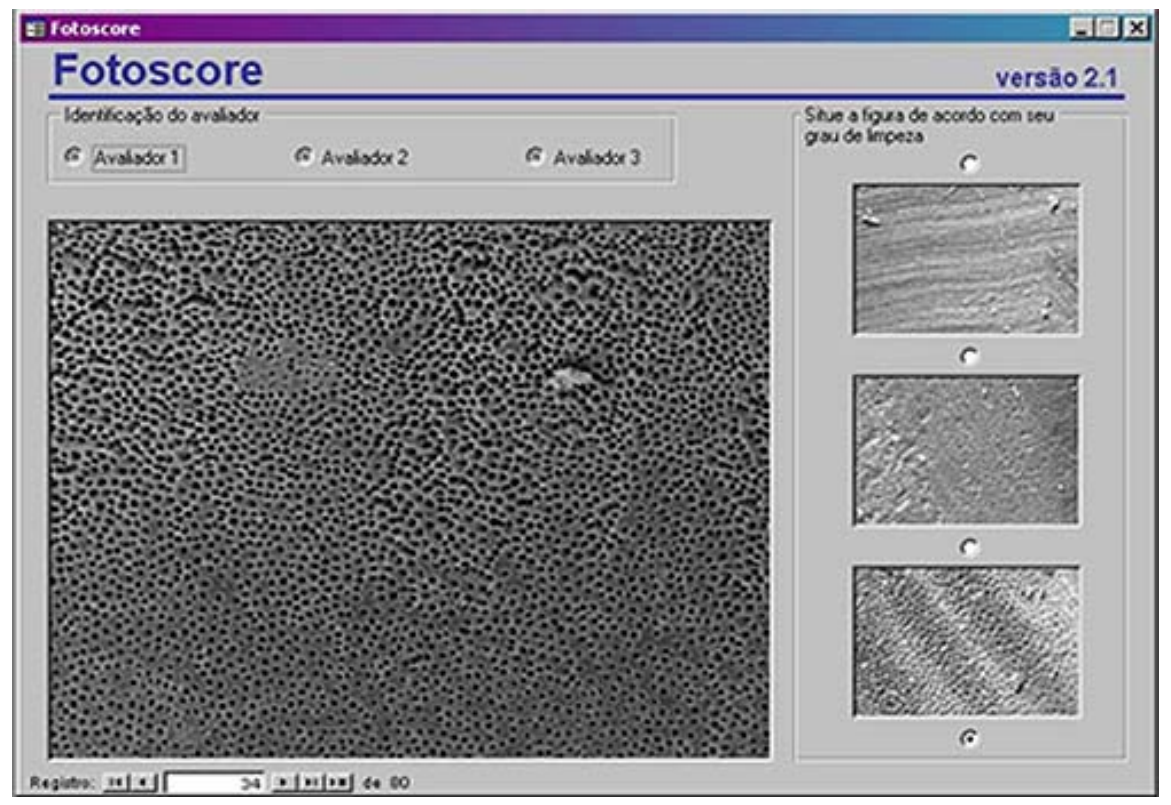

Figura 9 - Interface gráfica do software "Fotoscore", desenvolvido para a automação da atribuição de escores as fotomicrografias 
Após a avaliação e atribuição dos escores referentes a cada fotomicrografia, os dados foram inseridos no programa GMC versão 8.0, de autoria do Prof. Dr. Geraldo Maia Campos FORP.USP, e os resultados foram submetidos à análise estatística. 
O conjunto matemático do presente estudo é composto por dois fatores de variação. O primeiro fator, chamado de "Tratamentos", é composto por quatro componentes independentes (hipoclorito de sódio a 2,5\%, hipoclorito de sódio a 2,5\% alternado com EDTA, água destilada + laser Er: YAG nos parâmetros de $10 \mathrm{~Hz}, 140$ mJ e água destilada + laser Er: YAG nos parâmetros de 10 Hz, 250 mJ). O segundo fator de variação denominado "Terços Radiculares" apresenta dois componentes vinculados (médio e apical). O número total de dados é de 80 valores numéricos de natureza ordinal, obtidos a partir da moda dos escores atribuídos pelos diferentes examinadores das fotomicrografias (Anexo A, B, C e D). Este número total de dados é advindo do produto fatorial de quatro tratamentos, dois terços radiculares e dez repetições (Tabela 1). 
Tabela 1 - Moda dos escores atribuídos pelos diferentes examinadores as fotomicrografias

\begin{tabular}{|c|c|c|c|c|c|}
\hline \multirow[t]{2}{*}{ Terços } & \multicolumn{5}{|c|}{ Tratamentos } \\
\hline & & & $\mathrm{Na} \mathrm{OCL}+$ & $\mathrm{Na} \mathrm{OCL}+$ & Soma dos \\
\hline & $\mathrm{NaOCl} 2,5 \%$ & $\mathrm{NaOCl}+\mathrm{EDTA}$ & Laser $140 \mathrm{~mJ}$ & Laser $250 \mathrm{~mJ}$ & escores \\
\hline & 4 & 3 & 4 & 4 & \\
\hline & 4 & 4 & 4 & 3 & \\
\hline & 4 & 2 & 3 & 4 & \\
\hline & 4 & 2 & 4 & 2 & \\
\hline \multirow[t]{10}{*}{ Apical } & 4 & 3 & 4 & 4 & 129 \\
\hline & 4 & 1 & 3 & 1 & \\
\hline & 4 & 1 & 3 & 3 & \\
\hline & 3 & 1 & 4 & 4 & \\
\hline & 4 & 2 & 4 & 4 & \\
\hline & 4 & 3 & 4 & 2 & \\
\hline & 4 & 1 & 3 & 3 & \\
\hline & 3 & 1 & 3 & 4 & \\
\hline & 3 & 1 & 3 & 4 & \\
\hline & 4 & 1 & 3 & 1 & \\
\hline \multirow[t]{6}{*}{ Médio } & 4 & 1 & 3 & 3 & \\
\hline & 3 & 2 & 3 & 1 & 104 \\
\hline & 4 & 1 & 4 & 3 & \\
\hline & 3 & 2 & 3 & 1 & \\
\hline & 4 & 1 & 3 & 2 & \\
\hline & 4 & 2 & 4 & 1 & \\
\hline Soma dos escores & 75 & 35 & 69 & 54 & \\
\hline
\end{tabular}


Foi realizada a soma dos escores dos diferentes tratamentos testados e dos terços apicais observados, evidenciando diferenças em termos absolutos. Para elucidar a significância dessas diferenças, os dados obtidos deveriam ser submetidos a testes estatísticos.

Devido à natureza ordinal dos dados amostrais, tornava-se necessário a utilização de testes estatísticos não-paramétricos para determinar diferenças significantes entre os tratamentos e terços radiculares. Para os diferentes tratamentos testados, foi utilizado o teste de Kruskal-Wallis (não-paramétrico, amostras independentes, comparações múltiplas), enquanto para os diferentes terços o teste utilizado foi o de Wilcoxon (não-paramétrico, amostras vinculadas, comparações entre as duas amostras).

A análise estatística pelo teste de Kruskal-wallis revelou diferenças significantes ao nível de $1 \%$ para os diferentes tratamentos testados (Tabela 2).

Tabela 2 - Resultados do teste de Kruskal-Wallis para os diferentes tratamentos

$\begin{array}{lc}\text { Valor }(\mathrm{H}) \text { de Kruskal-Wallis calculado : } & 35.0442 \\ \text { Valor do } \mathrm{X}^{2} \text { para } 3 \text { graus de liberdade: } & 35.04 \\ \text { Probabilidade de Ho para esse valor: } & 0.00 \% \\ \qquad \text { Significante ao nível de } 1 \%(\alpha=0,01)\end{array}$

No intuito de esclarecer quais tratamentos testados seriam significantemente diferentes entre si, efetuou-se o teste estatístico de Dunn realizando comparações múltiplas, duas a duas, entre as médias dos postos das amostras (Tabela 3). 
Tabela 3 - Comparações múltiplas duas a duas entre médias dos postos das amostras

\begin{tabular}{|c|c|c|c|c|c|}
\hline \multirow{2}{*}{$\begin{array}{l}\text { Amostras comparadas } \\
\text { (comparações duas a duas) }\end{array}$} & \multirow{2}{*}{$\begin{array}{l}\text { Diferenças } \\
\text { entre médias }\end{array}$} & \multicolumn{3}{|c|}{ Valores críticos $(\alpha)$} & \multirow[t]{2}{*}{ Significância } \\
\hline & & 0,05 & 0,01 & 0.001 & \\
\hline $\mathrm{NaOCl}$ X NaOCl+EDTA: & 38.8000 & 10.5818 & 14.0506 & 18.2324 & $1 \%$ \\
\hline $\mathrm{NaOCl} \mathrm{X}$ laser $140 \mathrm{~mJ}+\mathrm{NaOCL}$ : & 8.4000 & 10.5818 & 14.0506 & 18.2324 & ns \\
\hline NaOCL X laser 250mJ+NaOCL: & 20.8000 & 10.5818 & 14.0506 & 18.2324 & $0,1 \%$ \\
\hline $\mathrm{NaOCL}+\mathrm{EDTA} \quad \mathrm{X}$ laser $140 \mathrm{~mJ}+\mathrm{NaOCL}$ : & 30.4000 & 10.5818 & 14.0506 & 18.2324 & $0,1 \%$ \\
\hline $\mathrm{NaOCL}+\mathrm{EDTA} X$ laser $250 \mathrm{~mJ}+\mathrm{NaOCL}$ & 18.0000 & 10.5818 & 14.0506 & 18.2324 & $1 \%$ \\
\hline Laser $140 \mathrm{~mJ}$ X laser $250 \mathrm{~mJ}+\mathrm{NaOCL}$ : & 12.4000 & 10.5818 & 14.0506 & 18.2324 & $5 \%$ \\
\hline
\end{tabular}

ns = não significante

O teste complementar revelou que os canais tratados com hipoclorito de sódio e hipoclorito de sódio + laser Er: YAG 140 mJ formaram um grupo estatisticamente semelhante, apresentando a maior quantidade da "smear layer". Os canais tratados com hipoclorito de sódio alternado com EDTA apresentaram paredes dentinárias livres da "smear layer", com exposição de grande quantidade de túbulos. Permanecendo em posição intermediária, o laser Er: YAG $250 \mathrm{~mJ}$ removeu a "smear" de forma mais eficiente que os grupos hipoclorito de sódio e hipoclorito de sódio + laser Er: YAG 140 mJ, porém em menor intensidade que o grupo tratado com hipoclorito de sódio alternado com EDTA.

O gráfico apresentado na Figura 10, ilustra esta relação entre os tratamentos a partir da soma dos escores atribuídos às figuras avaliadas pelos examinadores. 


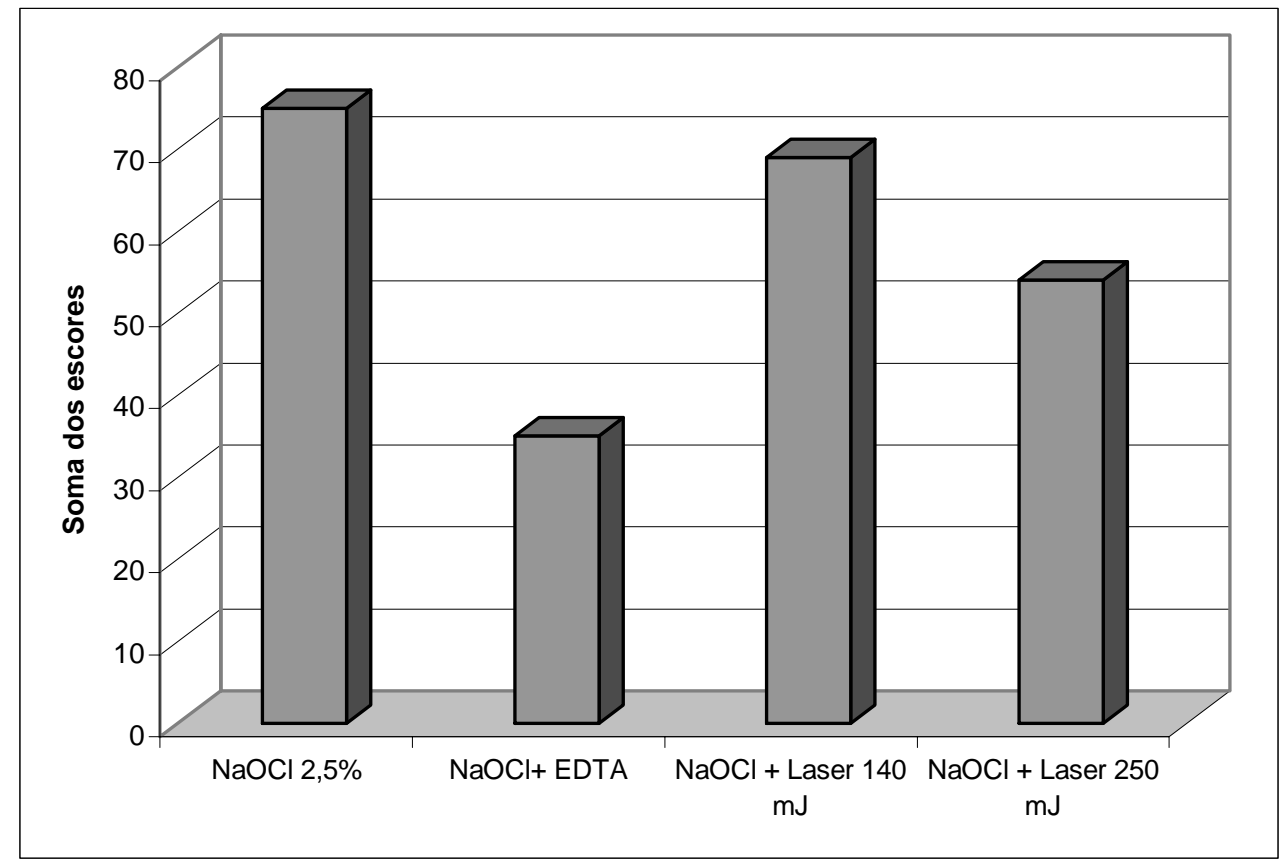

Figura 10 - Valores resultantes da somatória dos escores atribuídos pelos examinadores aos diferentes tratamentos

Para determinar se haviam diferenças estatísticas entre os terços radiculares, foi aplicado o teste de Wilcoxon (Tabela 4).

Tabela 4 - Resultado do teste de Wilcoxon para os terços radiculares

Valor de z calculado pelo teste:

Probabilidades de Ho para esse valor de z:
a) em testes monocaudais:
$0.0421 \%$
b) em testes bicaudais:
$0.0842 \%$

Significante ao nível de $1 \%(\alpha=0.01)$ (para o teste monocaudal)

Na Tabela 1, a soma dos escores do terço médio revelou-se menor que a soma dos escores do terço apical. A utilização de um teste estatístico se fazia necessário para determinar se esta diferença em números absolutos seria significante. 
Pelo fato de se assumir como hipótese alternativa $\left(\mathrm{H}_{1}\right)$ apenas a diferença entre a quantidade da "smear" entre os terços radiculares sem se afirmar qual deles seria o mais limpo, utilizou-se a probabilidade $\left(\mathrm{H}_{0}\right)$ para o valor de $\mathrm{z}$ calculado em testes monocaudais $(0.0421 \%)$. Este teste revelou diferença estatística significante ao nível de $1 \%$ entre os terços apical e médio dos canais radiculares. Desta forma, comprova-se que o menor valor obtido na soma dos escores do terço médio reflete em menor quantidade da camada de "smear" encontrada nesta área em comparação ao terço apical. O gráfico apresentado na Figura 11 ilustra esta relação de diferença entre os terços radiculares.

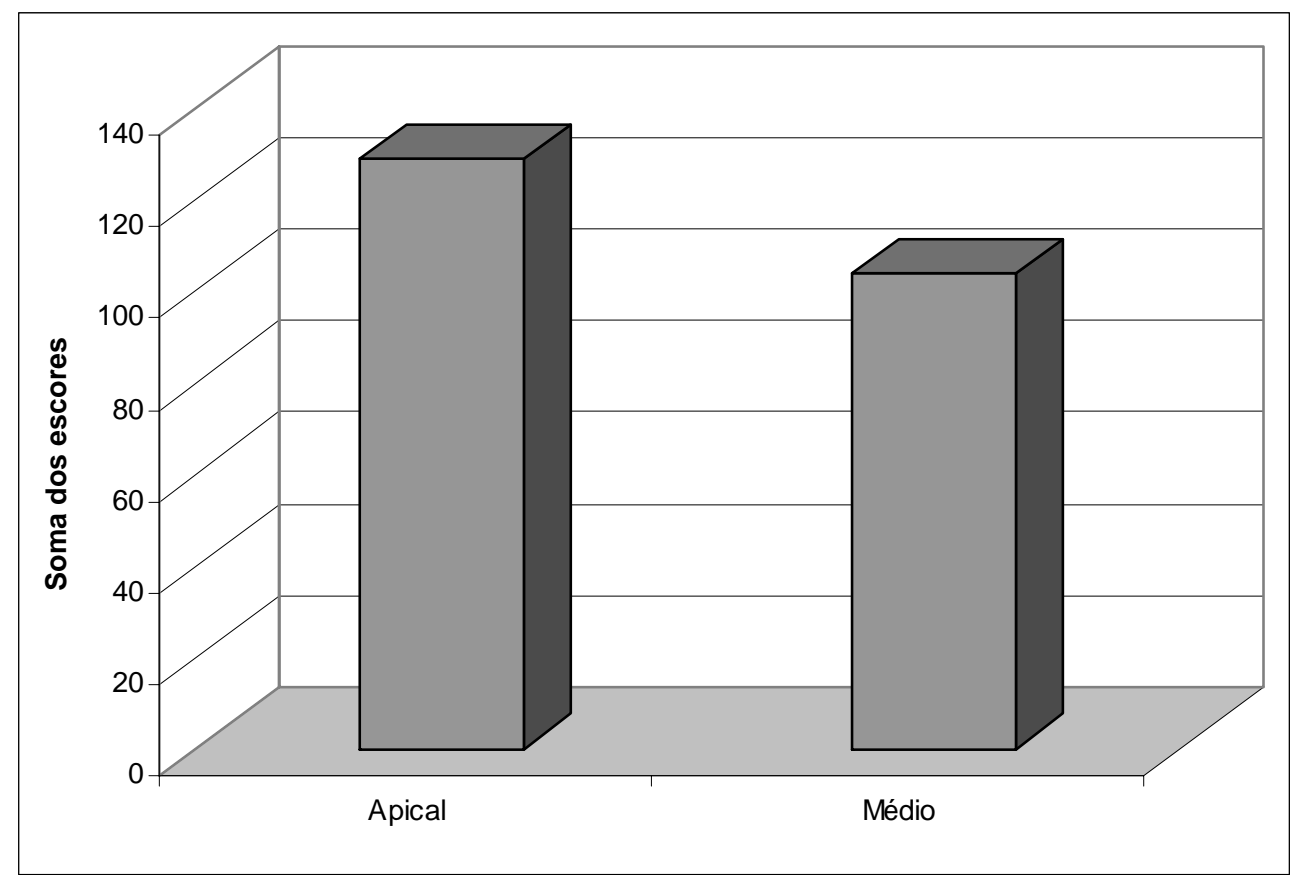

Figura 11 - Valores obtidos a partir da soma dos escores atribuídos pelos examinadores aos terços radiculares

As Figuras 12 a 15 mostram fotomicrografias eletrônicas de varredura das superfícies dentinárias dos terços apicais, e a seguir. As Figuras 16 a 19 mostram as fotomicrografias eletrônicas de varredura das superfícies dentinárias dos terços médios dos canais radiculares estudados. 


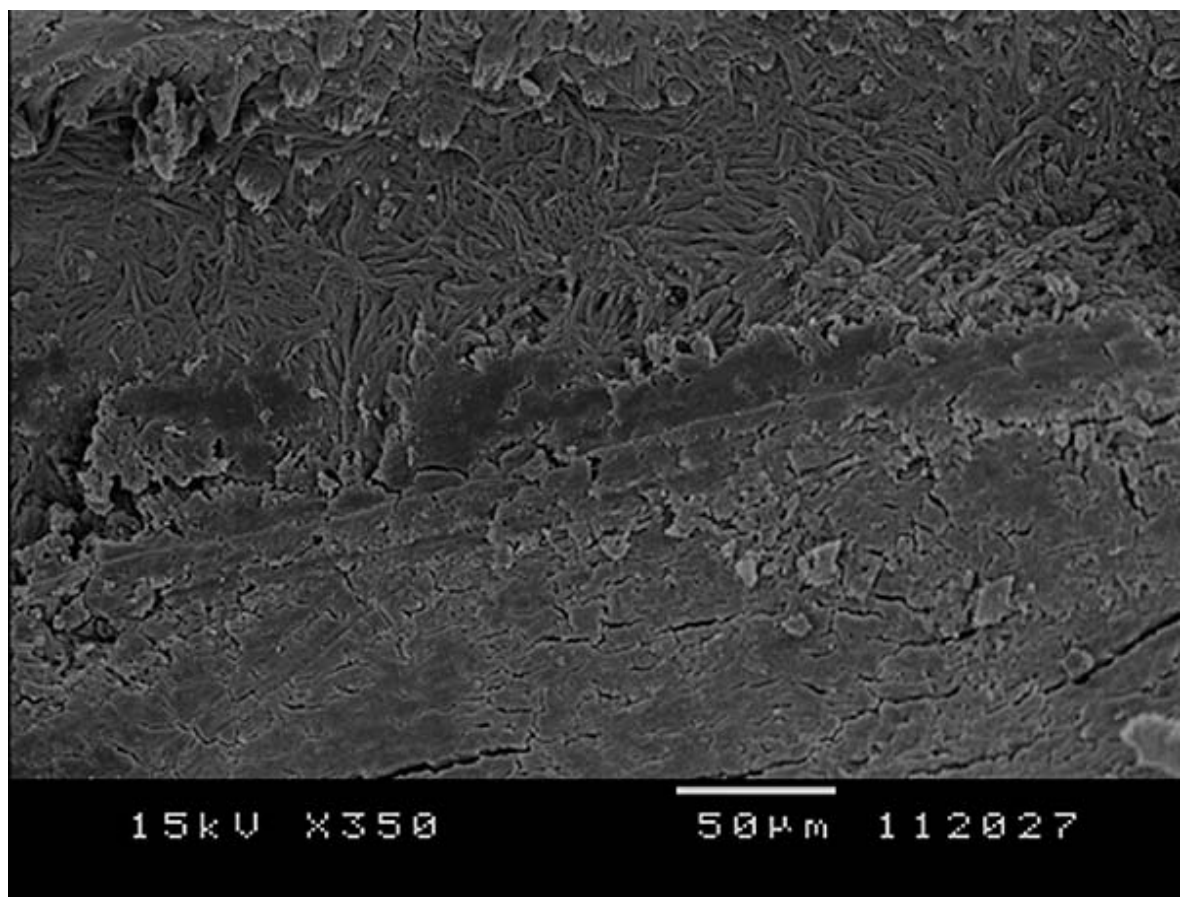

Figura 12 - Fotomicrografia eletrônica de varredura da porção apical do canal radicular após a instrumentação com hipoclorito de sódio a 2,5\%

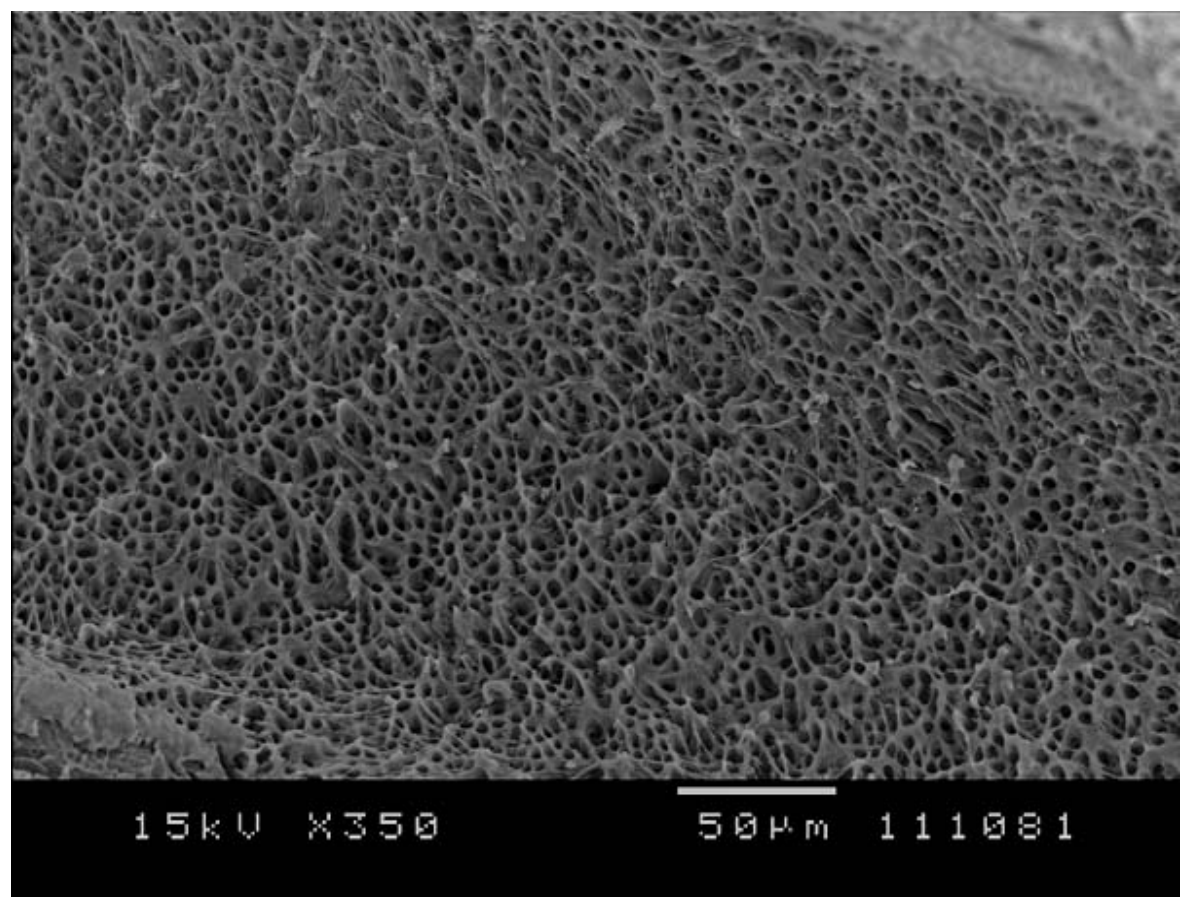

Figura 13 - Fotomicrografia eletrônica de varredura da porção apical do canal radicular após a instrumentação com hipoclorito de sódio a 2,5\% alternado com EDTA a $17 \%$ 


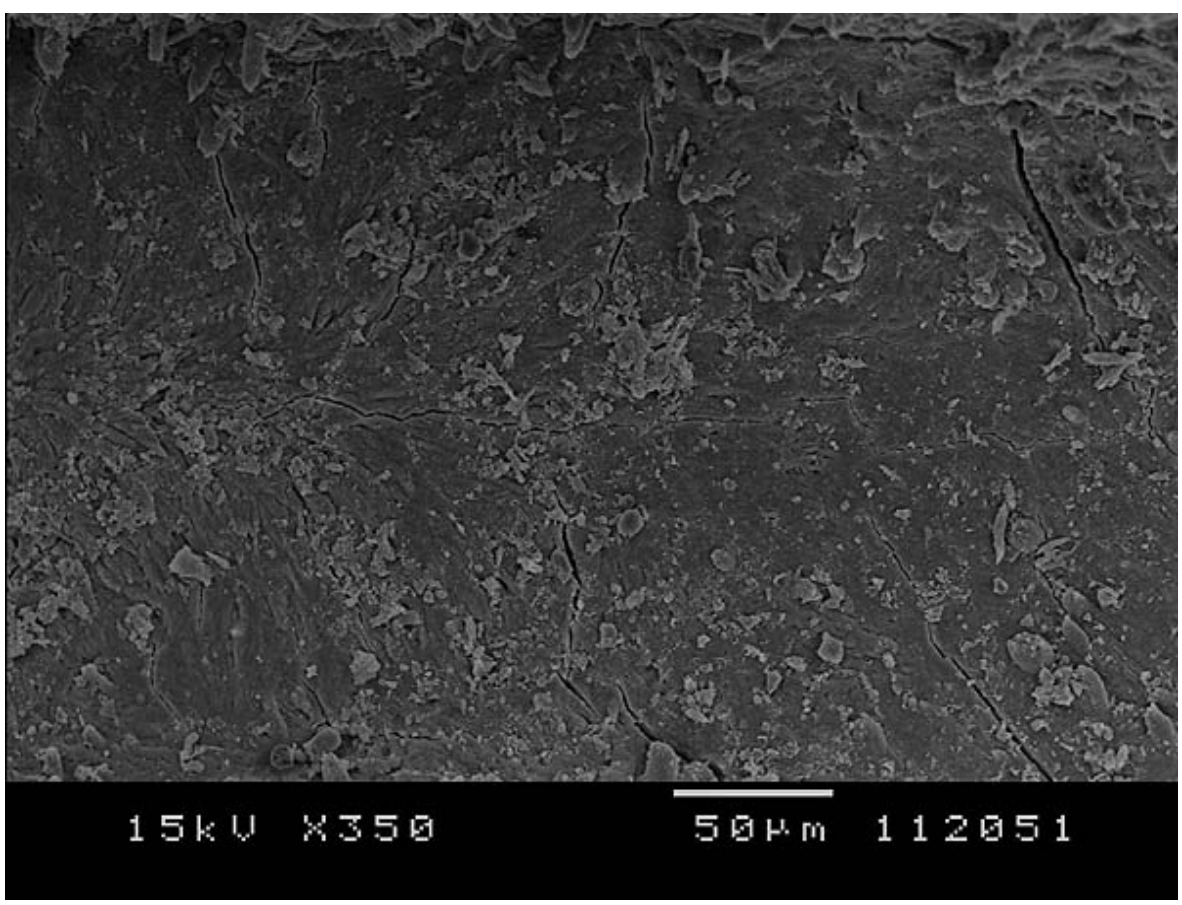

Figura 14 - Fotomicrografia eletrônica de varredura da porção apical do canal radicular após a instrumentação com hipoclorito de sódio a 2,5\% e irradiação com laser Er: YAG nos parâmetros de 140 mJ e $10 \mathrm{~Hz}$

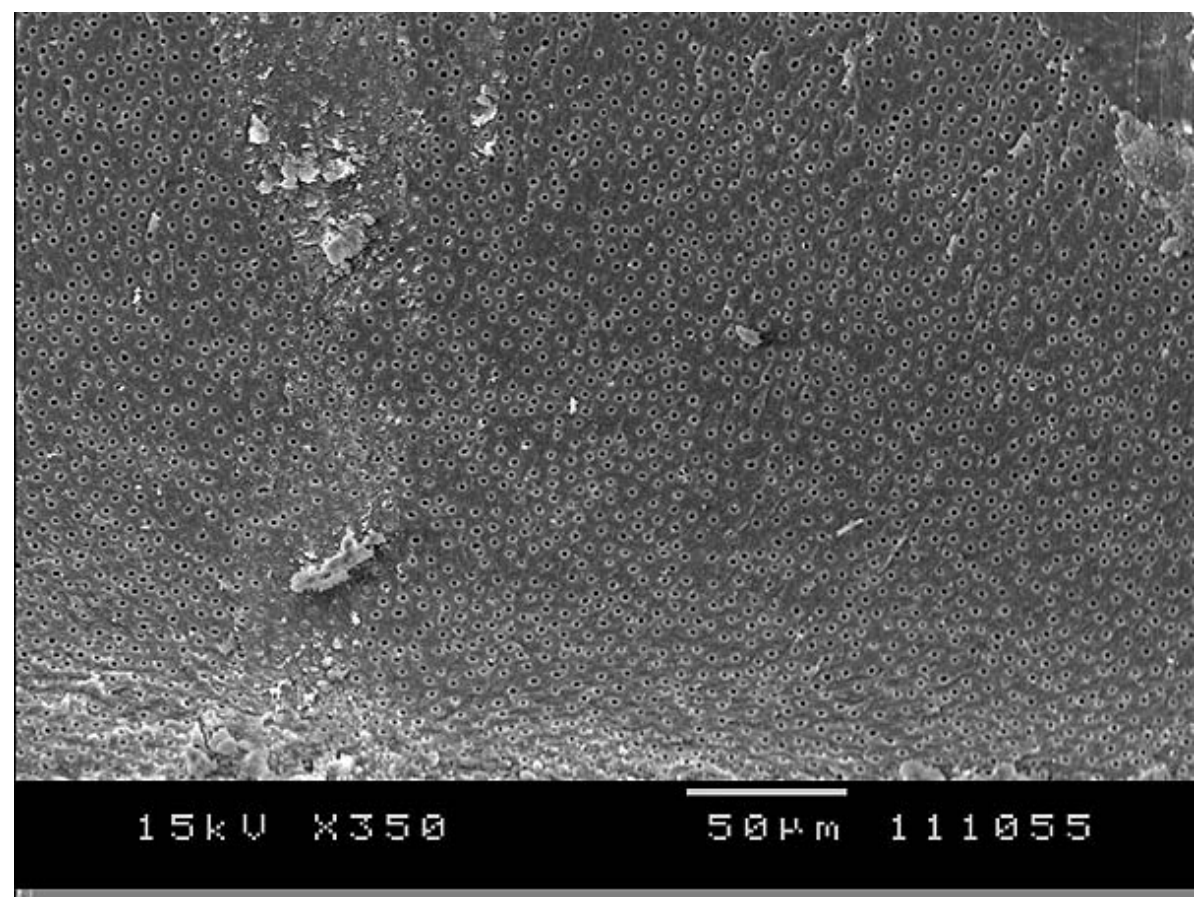

Figura 15 - Fotomicrografia eletrônica de varredura da porção apical do canal radicular após a instrumentação com hipoclorito de sódio a 2,5\% e irradiação com laser Er: YAG nos parâmetros de 250 mJ e $10 \mathrm{~Hz}$ 


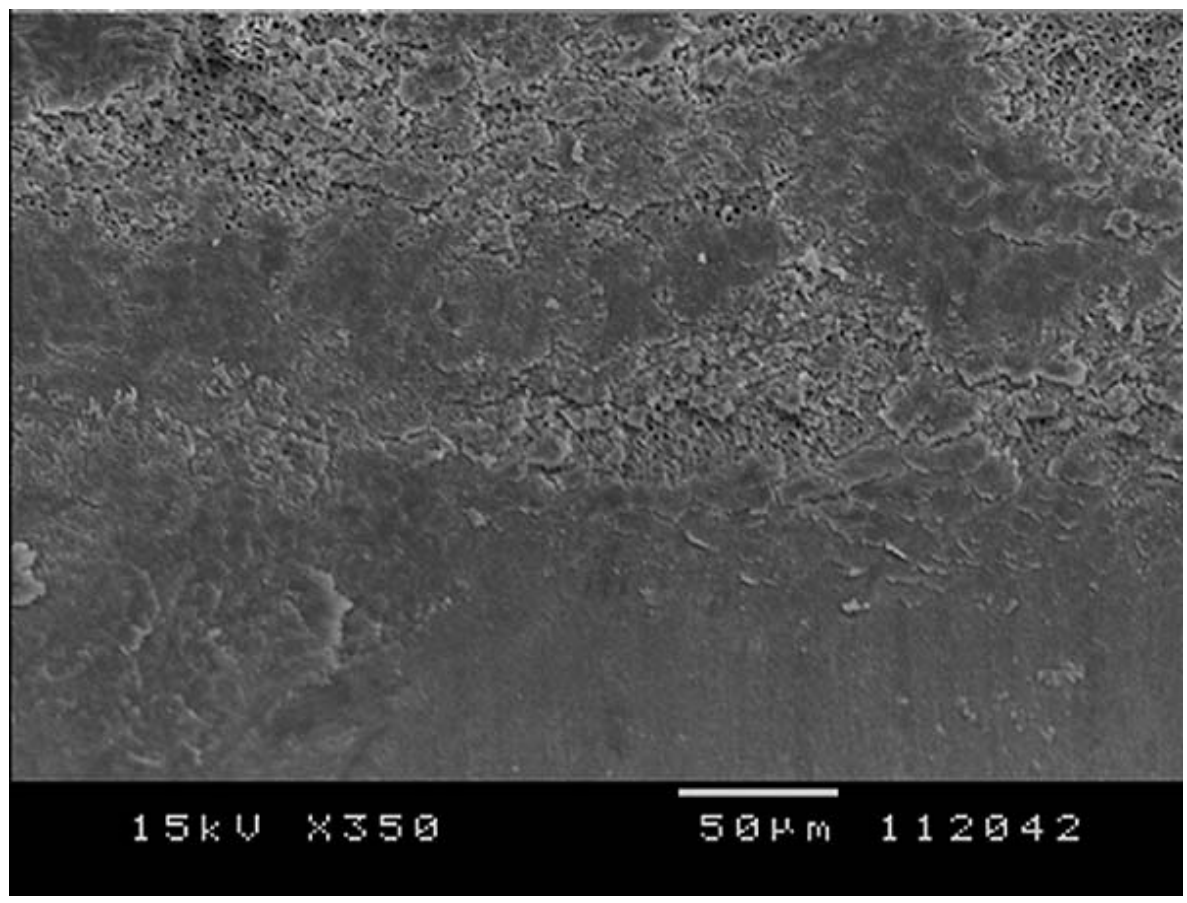

Figura 16 - Fotomicrografia eletrônica de varredura da porção média do canal radicular após a instrumentação com hipoclorito de sódio a 2,5\%

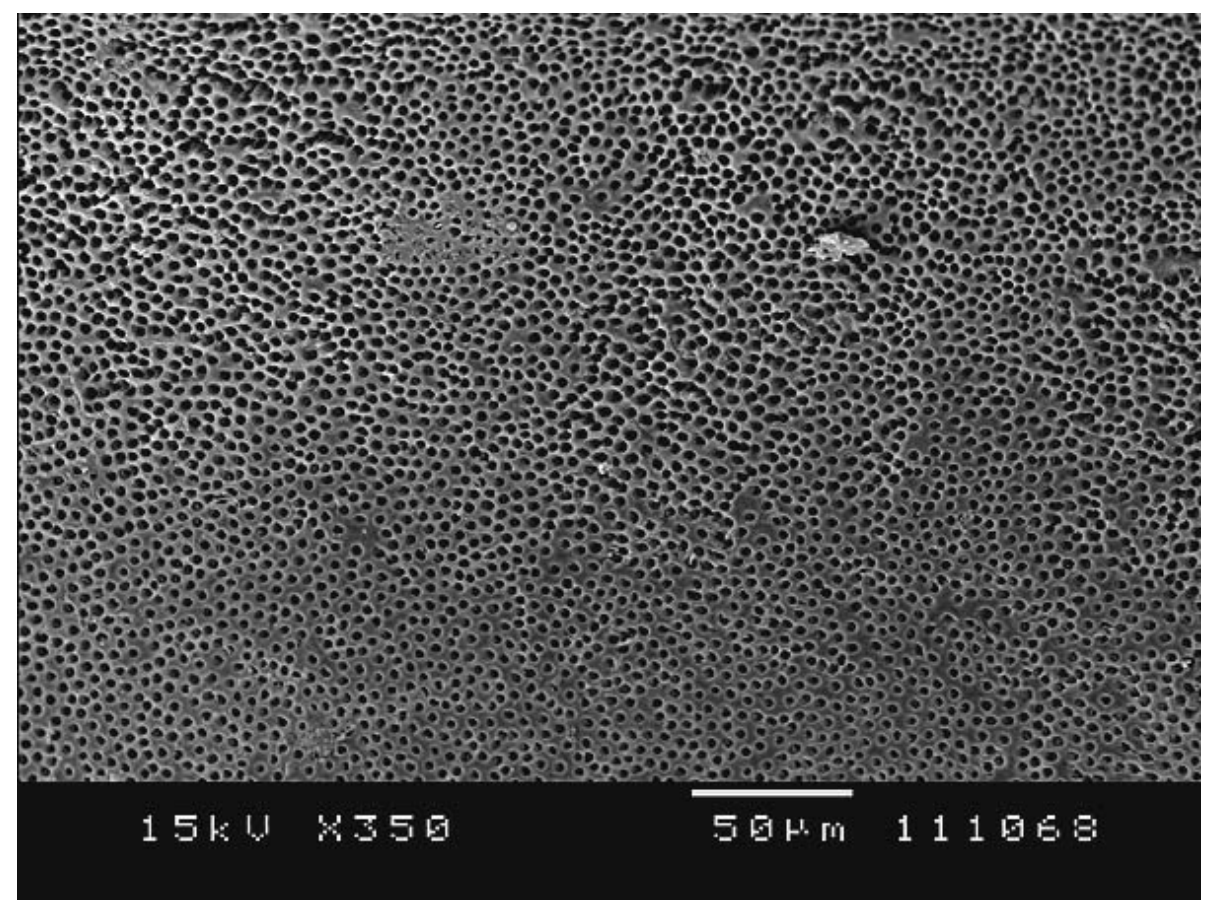

Figura 17 - Fotomicrografia eletrônica de varredura da porção média do canal radicular após a instrumentação com hipoclorito de sódio a 2,5\% alternado com EDTA a $17 \%$ 


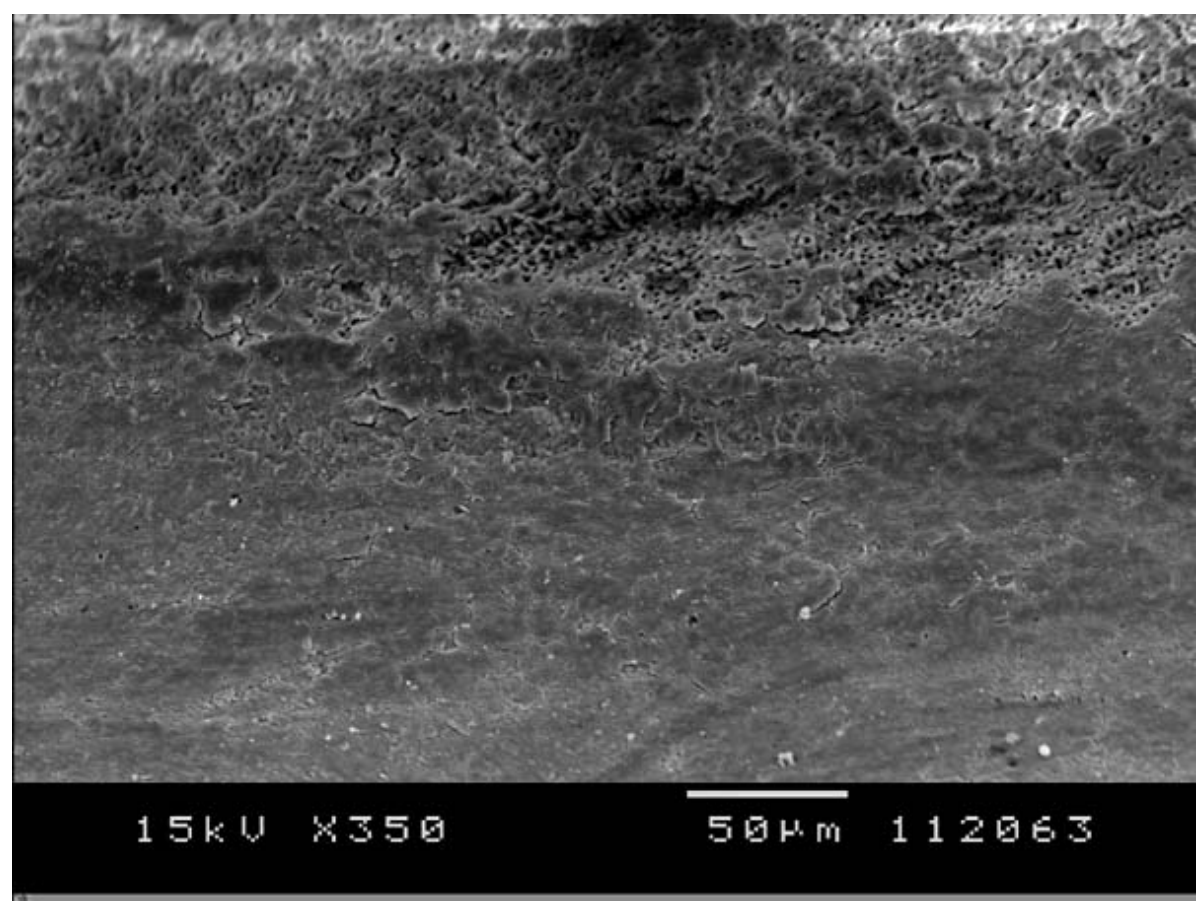

Figura 18 - Fotomicrografia eletrônica de varredura da porção média do canal radicular após a instrumentação com hipoclorito de sódio a 2,5\% e irradiado com laser Er: YAG nos parâmetros de $140 \mathrm{~mJ}$ e $10 \mathrm{~Hz}$

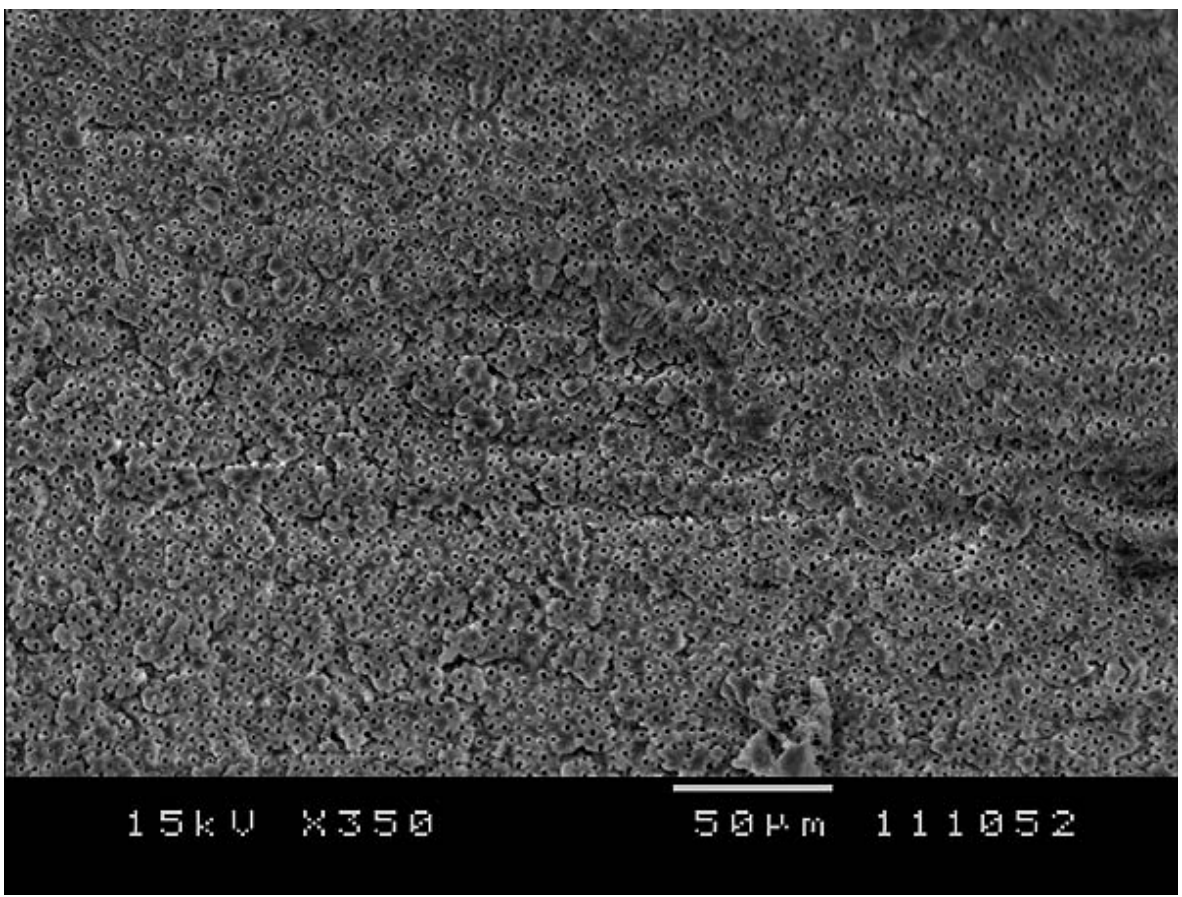

Figura 19 - Fotomicrografia eletrônica de varredura da porção média do canal radicular após a instrumentação com hipoclorito de sódio a 2,5\% e irradiado com laser Er: YAG nos parâmetros de $250 \mathrm{~mJ}$ e $10 \mathrm{~Hz}$ 
O sucesso na terapêutica endodôntica fundamenta-se principalmente em vários fatores, tais como limpeza, desinfecção, modelagem e obturação dos canais radiculares, possibilitando assim a conservação do elemento dental.

A complexidade da anatomia interna do sistema de canais radiculares, bem como o achatamento das raízes, são aspectos que dificultam a instrumentação das regiões polares dos canais radiculares, suas limpezas e modelagens, já que se constituem em regiões de difícil acesso ao instrumento endodôntico. Para auxiliar na desinfecção das regiões onde os instrumentos não alcançam, faz-se necessário o auxílio de substâncias e recursos que penetrem 
nessas regiões, de modo a remover o conteúdo orgânico presente no sistema de canais radiculares, inviabilizando o desenvolvimento, ou até mesmo a existência, de microrganismos (Kutler, 1955; Gutierrez \& Garcia, 1968; Davis et al., 1972; Moodnik et al., 1976; Shilder, 1974; Walton, 1976; Siqueira et al., 1997, Cohen \& Burns, 1998).

Para esse fim, o hipoclorito de sódio, nas mais variadas concentrações, é uma solução irrigadora amplamente aceita pelos seus bons resultados no auxílio ao esvaziamento do sistema de canais radiculares (De Deus, 1992).

Ele atua associado à aspiração dos canais radiculares, ação esta que demanda um certo tempo de contato da solução com as paredes do canal radicular (Pécora et al., 1999).

Após estudar a eficiência das várias concentrações de hipoclorito de sódio, Kokinen et al. (1980), Gordon et al. (1981) e Spanó et al. (2001) são categóricos ao afirmar que, quanto maior a concentração desta solução, menor será o tempo necessário para que o processo bactericida e de dissolução tecidual ocorram.

Desta forma, como salientado anteriormente, o tempo de exposição das paredes do canal radicular à solução irrigante é de vital importância para a seleção de sua concentração ideal, que será utilizada no preparo dos canais radiculares. Por esse motivo, como nesse estudo utilizou-se a instrumentação rotatória, que demanda menor tempo para o preparo dos canais (Lopes, 1999), o contato da solução irrigante com as paredes do canal radicular foi reduzido, o que faz supor a necessidade de se aumentar a concentração da solução auxiliar. Sendo assim, utilizou-se a solução de hipoclorito de sódio a 2,5\%.

$\mathrm{O}$ ato da instrumentação dos canais radiculares produz grande quantidade de "smear", o que dificulta a penetração das soluções irrigadoras auxiliares no interior dos túbulos 
dentinários. Como o hipoclorito de sódio é incapaz de remover esse sub-produto da instrumentação, já que não age na matriz mineral do dente (McComb \& Smith, 1975), faz-se necessária a ação de uma substância ou mecanismo que seja eficiente na remoção da camada de "smear".

Desta forma, houve a necessidade da associação alternada de um quelante para auxiliar o hipoclorito de sódio, ou melhor, um agente desmineralizante que tivesse ação na matriz mineral do dente, para que a camada de "smear" fosse efetivamente removida.

A utilização de agentes desmineralizadores na instrumentação dos canais radiculares não é recente. Callahan (1894) preconizou o uso de um ácido sulfúrico a 40\% na instrumentação de canais radiculares atresiados como solução auxiliar, uma vez que este ácido reagia com o cálcio da dentina, formando o sulfato de cálcio, desmineralizando o tecido dentinário. Como este ácido é extremamente forte, Grossman (1946) preferiu, ao invés do ácido sulfúrico, a utilização do ácido clorídrico, uma vez que este ao reagir com o cálcio da dentina forma o cloreto de cálcio, que é mais solúvel que o sulfato de cálcio.

Esta metodologia perdurou por muito tempo, até que Østby (1957) propôs a instrumentação de canais atresiados com uma solução de etileno diamino tetracético sal dissódico (EDTA). Esta solução resulta de um ácido fraco e é capaz de promover a quelação de íons de cálcio da dentina, em $\mathrm{pH}$ neutro.

Ao descalcificar a dentina, a solução de EDTA também remove a camada de "smear" gerada após a instrumentação dos canais radiculares (McComb \& Smith, 1975). 
A associação do hipoclorito de sódio ao EDTA não trouxe problemas, já que uma solução não neutraliza e nem interfere na outra (Saquy, 1991). O que ocorre apenas é a ação do hipoclorito de sódio na matriz orgânica e do EDTA na matriz mineral do dente.

A afirmação do autor citado no parágrafo anterior é comprovada pelos resultados aqui obtidos, em que o grupo 1, formado por dentes tratados apenas com solução de hipoclorito de sódio, apresentou níveis bem menores de remoção da camada de "smear" do que o grupo 4, em que os dentes sofreram tratamento com solução de hipoclorito de sódio alternado com EDTA, e apresentaram túbulos abertos e livres dessa camada.

Para o preparo dos canais radiculares, foi escolhida a instrumentação rotatória por seus resultados promissores na Endodontia, tais como rapidez no preparo, flexibilidade dos instrumentos e modelagem das paredes dos canais radiculares.

Com o advento da instrumentação rotatória e o uso de limas de NiTi acionadas a motor, surgiram as fraturas nos instrumentos, relacionadas com as suas cinemáticas de uso no alargamento dos canais radiculares. Várias técnicas foram desenvolvidas para minimizar o problema, mas sem sucesso. Nessas técnicas, a ponta do instrumento, mais frágil por apresentar menor quantidade de massa metálica, ficava sob intenso esforço. Os instrumentos de maior calibre eram utilizados inicialmente, submetendo sua extremidade a maiores cargas, o que resultava em fraturas.

Para McSpadden (1996) e Bassi (2002), os instrumentos rotatórios de NiTi fraturam-se na região inicial da parte ativa quando esta se prende, ou seja, na ponta do instrumento, a 2 ou 3 milímetros do guia de penetração. Deste modo, uma técnica em que as limas fizessem o preparo e apresentassem a ponta livre ou com estresse reduzido, diminuiria o risco de fratura dos instrumentos. 
Com o intuito de minimizar o número de fraturas nos instrumentos, surge a técnica "Free Tip Preparation" (Pécora et al., 2002), em que a ponta do instrumento mantém-se livre do estresse gerado na instrumentação, justificando-se, dessa forma, a adoção desta técnica no presente estudo.

Outro recurso coadjuvante, que tem sido utilizado na terapia endodôntica, é o laser de alta potência que desde o desenvolvimento do "Maser" por Maiman (1960), sofreu grande desenvolvimento. Os aparelhos de hoje são mais sofisticados que seus precursores e são pesquisados exaustivamente na tentativa de provar os seus valores como recursos terapêuticos.

Na atualidade, um dos lasers mais estudados é o de Er: YAG, por apresentar facilidade no corte de tecidos duros com alterações térmicas mínimas (Keller \& Hibst, 1989 e Visuri et al., 1996). Ademais, provoca alterações radiculares superficiais similares ao condicionamento ácido, o que faz com que a camada de “smear" seja removida, expondo os túbulos dentinários, sem resultar em fusão e carbonização da dentina (Cobb et al. 1997).

Alguns trabalhos, como os de Takahashi et al. (1996), mostraram que, após a irradiação com o laser de Er: YAG, a maior parte de "débris" e "smear" foi removida, e os túbulos dentinários ficaram evidenciados. Resultados semelhantes foram encontrados por Takeda et al. (1998) e Takeda et al. (1999). Esses resultados foram obtidos por meio da visualização com microscopia eletrônica de varredura, com aumento de 1000X.

O laser de Er: YAG age por micro-explosões da água contida nos tecidos dentinários, conhecida como ablação, que aconteceu onde a luz proveniente da ponta da fibra óptica alcança. Devido a isso, a remoção da "smear" não é contínua.

As pesquisas realizadas têm mostrado bons resultados da utilização do laser de Er: YAG quanto à remoção da camada de "smear" e "débris". Porém, neste método, a área examinada é pequena, o que faz com que as superfícies visualizadas mostrem sempre bons resultados, uma 
vez que se pode escolher apenas regiões onde o laser é eficiente para o fim da pesquisa. Por esta razão, e embasado em estudos como os de Guerisoli (2002) e Brugnera et al. (2002), optou-se pelo aumento de $350 \mathrm{X}$, que permite o exame de maior área com o intuito de visualizar resultado da ação do laser de Er: YAG quanto à sua capacidade de limpeza.

Brugnera et al. (2002), ao avaliar a remoção da "smear" dos canais radiculares após a aplicação de diferentes agentes quelantes e do laser de Er: YAG com parâmetro de 140 mJ e $15 \mathrm{~Hz}$, demonstraram que o grupo instrumentado apenas com EDTA foi o que apresentou menor quantidade da camada de "smear".

Guerisoli (2002), estudando a remoção da camada de "smear" dos canais radiculares após a aplicação de agentes quelantes como o CDTA, EGTA na concentração de 1\%, EDTA a 15\% e do laser Er: YAG com parâmetro de $140 \mathrm{~mJ}$ e $15 \mathrm{~Hz}$, demonstrou que o grupo instrumentado com EDTA apresentou os melhores resultados, ou seja, menor quantidade da “smear”, o que está em consonância com os achados de Brugnera et al. (2002).

No presente trabalho, resultados semelhantes foram obtidos, já que o grupo dos dentes tratados com EDTA assumiu posição de destaque perante os demais ao apresentar menor quantidade da "smear" remanescente. A diferença foi que, para este experimento, utilizou-se também o laser de Er: YAG com os parâmetros de 140 mJ e 10Hz (grupo 2) e de 250 mJ e 10 $\mathrm{Hz}$ (grupo 3), verificando-se melhor remoção da "smear" no grupo 3, o que indica que o aumento da potência do laser parece ser diretamente proporcional à remoção da “smear".

Comparando-se o grupo 3 aos demais, ele permaneceu em posição intermediária em relação ao grupo 4 (NaOCL 2,5\% + EDTA) e aos grupos 1 (NaOCL 2,5\%) e 2 (NaOCL 2,5\% + laser $140 \mathrm{~mJ}$ ), sendo que estes últimos não apresentaram diferenças estatísticas significantes entre si. 
A utilização do laser de Er: YAG, como coadjuvante do preparo biomecânico depende da solução de alguns problemas, tais como a flexibilidade da fibra óptica e o modo de direção do foco. Sendo a fibra óptica rígida, e o raio laser saindo pela sua extremidade, a ação do laser restringe-se somente onde houver contato da fibra com as paredes da dentina, de forma a constituir, assim, uma limitação a ser solucionada.

No futuro, com a evolução do laser, e diminuição das limitações da sua aplicabilidade, poderá ele substituir outros coadjuvantes na terapêutica endodôntica. Cabe aos pesquisadores, bem como às empresas, o desenvolvimento de aparelhos que não apresentem as deficiências dos até hoje fabricados e estudados. Pesquisas devem ser realizadas com o fito de solucionar os problemas e deficiências apontadas, bem como para o aperfeiçoamento da tecnologia a serviço da Odontologia, em especial o estabelecimento de parâmetros seguros de utilização do laser, com a melhoria do seu custo-benefício para uso profissional. 

De acordo com a metodologia aplicada e com a análise dos resultados obtidos, pode-se concluir que, quanto à quantidade da camada de "smear" remanescente após a instrumentação nos grupos, o grupo do Hipoclorito de sódio a 2,5\% e o do laser de Er: YAG no parâmetro de $140 \mathrm{~mJ}$ e $10 \mathrm{~Hz}$ apresentaram a maior quantidade da camada de "smear", sem diferença estatística entre si. O grupo em que laser foi utilizado com o parâmetro de $250 \mathrm{~mJ}$ e $10 \mathrm{~Hz}$ apresentou resultado intermediário. Por fim, o melhor resultado, ou seja, a menor quantidade da camada de "smear", foi encontrada no grupo em que se associou Hipoclorito de sódio a 2,5\% alternado com EDTA a $17 \%$. 
Quanto à quantidade da camada de "smear" nos terços, o apical apresentou os piores resultados, ou seja, maior quantidade de "smear" em comparação ao terço médio. 
Anexo A - Escores atribuídos pelos diferentes examinadores as fotomicrografias do grupo 1

\begin{tabular}{|c|c|c|c|c|}
\hline Amostra & Avaliador 1 & Avaliador 2 & Avaliador 3 & Moda \\
\hline NaOCl apical & 4 & 4 & 3 & 4 \\
\hline NaOCl apical & 4 & 4 & 4 & 4 \\
\hline $\mathrm{NaOCl}$ apical & 4 & 4 & 4 & 4 \\
\hline NaOCl apical & 4 & 4 & 4 & 4 \\
\hline NaOCl apical & 4 & 4 & 4 & 4 \\
\hline NaOCl apical & 4 & 4 & 4 & 4 \\
\hline $\mathrm{NaOCl}$ apical & 4 & 4 & 4 & 4 \\
\hline NaOCl apical & 2 & 4 & 3 & 3 \\
\hline NaOCl apical & 3 & 4 & 4 & 4 \\
\hline NaOCl apical & 4 & 4 & 4 & 4 \\
\hline NaOCI médio & 2 & 4 & 4 & 4 \\
\hline NaOCI médio & 3 & 4 & 3 & 3 \\
\hline NaOCI médio & 3 & 4 & 3 & 3 \\
\hline NaOCI médio & 4 & 4 & 4 & 4 \\
\hline NaOCl médio & 3 & 4 & 4 & 4 \\
\hline NaOCI médio & 3 & 4 & 3 & 3 \\
\hline NaOCI médio & 4 & 4 & 4 & 4 \\
\hline NaOCI médio & 2 & 4 & 3 & 3 \\
\hline NaOCI médio & 3 & 4 & 4 & 4 \\
\hline NaOCI médio & 4 & 4 & 4 & 4 \\
\hline
\end{tabular}

Anexo B - Escores atribuídos pelos diferentes examinadores as fotomicrografias do grupo 2

\begin{tabular}{ccccc}
\hline Amostra & Avaliador 1 & Avaliador 2 & Avaliador 3 & Moda \\
\hline Laser 140 mJ + NaOCL apical & 4 & 4 & 4 & 4 \\
Laser 140 mJ + NaOCL apical & 4 & 4 & 4 & 4 \\
Laser 140 mJ + NaOCL apical & 3 & 4 & 2 & 3 \\
Laser 140 mJ + NaOCL apical & 4 & 4 & 3 & 4 \\
Laser 140 mJ + NaOCL apical & 4 & 4 & 4 & 4 \\
Laser 140 mJ + NaOCL apical & 2 & 4 & 3 & 3 \\
Laser 140 mJ + NaOCL apical & 3 & 4 & 3 & 3 \\
Laser 140 mJ + NaOCL apical & 4 & 4 & 4 & 4 \\
Laser 140 mJ + NaOCL apical & 4 & 4 & 4 & 4 \\
Laser 140 mJ + NaOCL apical & 4 & 4 & 2 & 4 \\
Laser 140 mJ + NaOCL médio & 2 & 4 & 3 & 3 \\
Laser 140 mJ + NaOCL médio & 3 & 3 & 2 & 3 \\
Laser 140 mJ + NaOCL médio & 3 & 4 & 3 & 3 \\
Laser 140 mJ + NaOCL médio & 3 & 4 & 3 & 3 \\
Laser 140 mJ + NaOCL médio & 3 & 4 & 3 & 3 \\
Laser 140 mJ + NaOCL médio & 2 & 3 & 3 & 3 \\
Laser 140 mJ + NaOCL médio & 3 & 4 & 4 & 4 \\
Laser 140 mJ + NaOCL médio & 2 & 3 & 3 & 3 \\
Laser 140 mJ + NaOCL médio & 3 & 3 & 2 & 3 \\
Laser 140 mJ + NaOCL médio & 3 & 4 & 4 & 4 \\
\hline
\end{tabular}


Anexo C - Escores atribuídos pelos diferentes examinadores as fotomicrografias do grupo 3

\begin{tabular}{ccccc}
\hline Amostra & Avaliador 1 & Avaliador 2 & Avaliador 3 & Moda \\
\hline Laser 250 mJ + NaOCL apical & 4 & 4 & 3 & 4 \\
Laser 250 mJ + NaOCL apical & 3 & 4 & 3 & 3 \\
Laser 250 mJ + NaOCL apical & 4 & 4 & 4 & 4 \\
Laser 250 mJ + NaOCL apical & 2 & 2 & 2 & 2 \\
Laser 250 mJ + NaOCL apical & 4 & 4 & 3 & 4 \\
Laser 250 mJ + NaOCL apical & 1 & 1 & 1 & 1 \\
Laser 250 mJ + NaOCL apical & 3 & 4 & 3 & 3 \\
Laser 250 mJ + NaOCL apical & 4 & 4 & 4 & 4 \\
Laser 250 mJ + NaOCL apical & 4 & 4 & 4 & 4 \\
Laser 250 mJ + NaOCL apical & 2 & 2 & 2 & 2 \\
Laser 250 mJ + NaOCL médio & 3 & 4 & 3 & 3 \\
Laser 250 mJ + NaOCL médio & 4 & 4 & 4 & 4 \\
Laser 250 mJ + NaOCL médio & 4 & 4 & 4 & 4 \\
Laser 250 mJ + NaOCL médio & 1 & 2 & 1 & 1 \\
Laser 250 mJ + NaOCL médio & 3 & 3 & 3 & 3 \\
Laser 250 mJ + NaOCL médio & 1 & 2 & 1 & 1 \\
Laser 250 mJ + NaOCL médio & 2 & 3 & 3 & 3 \\
Laser 250 mJ + NaOCL médio & 1 & 2 & 1 & 1 \\
Laser 250 mJ + NaOCL médio & 2 & 2 & 2 & 2 \\
Laser 250 mJ + NaOCL médio & 1 & 1 & 1 & 1 \\
\hline
\end{tabular}

Anexo D - Escores atribuídos pelos diferentes examinadores as fotomicrografias do grupo 4

\begin{tabular}{ccccc}
\hline Amostra & Avaliador 1 & Avaliador 2 & Avaliador 3 & Moda \\
\hline NaOCL+ EDTA apical & 3 & 3 & 1 & 3 \\
NaOCL+ EDTA apical & 4 & 4 & 4 & 4 \\
NaOCL+ EDTA apical & 2 & 4 & 2 & 2 \\
NaOCL+ EDTA apical & 2 & 2 & 3 & 2 \\
NaOCL+ EDTA apical & 3 & 4 & 3 & 3 \\
NaOCL+ EDTA apical & 1 & 1 & 1 & 1 \\
NaOCL+ EDTA apical & 1 & 1 & 1 & 1 \\
NaOCL+ EDTA apical & 1 & 1 & 1 & 1 \\
NaOCL+ EDTA apical & 2 & 3 & 1 & 2 \\
NaOCL+ EDTA apical & 3 & 3 & 3 & 3 \\
NaOCL+ EDTA médio & 1 & 1 & 1 & 1 \\
NaOCL+ EDTA médio & 1 & 1 & 2 & 1 \\
NaOCL+ EDTA médio & 1 & 1 & 1 & 1 \\
NaOCL+ EDTA médio & 1 & 1 & 1 & 1 \\
NaOCL+ EDTA médio & 1 & 2 & 1 & 1 \\
NaOCL+ EDTA médio & 2 & 2 & 2 & 2 \\
NaOCL+ EDTA médio & 1 & 1 & 1 & 1 \\
NaOCL+ EDTA médio & 1 & 2 & 2 & 2 \\
NaOCL+ EDTA médio & 1 & 1 & 1 & 1 \\
NaOCL+ EDTA médio & 2 & 2 & 3 & 2 \\
\hline
\end{tabular}



ABOU-RASS, M.; PICCININO, M. V. The effectiveness of four clinical irrigation methods on the removal of root canal debris. Oral. Surg. Oral Med. Oral Pathol., St. Louis, v. 54, n. 3, p. 323-328, Sept. 1982.

BADAN, M. Oxigenoargentoterapia. Mogi-Mirim: Pacini \& Piccolomini, 1949. 122 p.

BAKER, N. A. A scaning electron microscopic study of various irrigations solutions. J. Endod. Chicago,v. 1, n. 4, p.127-35, 1975.

BARBIN, E. L. Estudo in vitro do efeito da adição de lauril dietilenoglicol éter sulfato de sódio nas soluções de hipoclorito de sódio sobre as propriedades físico-químicas anteriores e posteriores à dissolução do tecido pulpar bovino. 1999. 108p. Dissertação 
(Mestrado)-Faculdade de Odontologia de Ribeirão Preto, Universidade de São Paulo, Ribeirão Preto.

BARBIZAM, J. V. B. Análise histológica da capacidade de limpeza promovida pela instrumentação rotatória com limas de níquel-titânio em canais radiculares com achatamento mésio-distal. 2000. 36p. Monografia (Especialização) Faculdade de Odontologia de Ribeirão Preto, Universidade de Ribeirão Preto, Ribeirão Preto.

BARBIZAM, J. V. B. Estudo "in vitro" da infiltração marginal coronária em canais radiculares obturados. 2001. 87p. Dissertação (Mestrado) Faculdade de Odontologia de Ribeirão Preto, Universidade de São Paulo, Ribeirão Preto.

BARBIZAM, J. V. B.; FARINIUK, L.F.; MARCHESAN, M.A.; PÉCORA, J.D.; SOUSANETO, M.D. Effectiveness of Manual and Rotary Instrumentation Techniques for Cleaning Flattened Root Canals. J. Endod., Chicago, v. 28, p. 365-366, 2002.

BARBOSA, S. V.; SAFAVI, K. E.; SPÅNGBERG, L. S. W. Influence of sodium hypochlorite on the permeability and structure of cervical human dentine. Int. Endod. J., Oxford, v. 27, p. 309-312, 1994.

BASSI, H. A. A. Sistema Easy-Endo-Multitaper. In: LEONARDO, M. R.; LEONARDO, R. T. Sistemas rotatórios em Endodontia - instrumentos de níquel-titânio. São Paulo: Artes Médicas, 2002, p. 287-314.

BAUMGARTNER, J. C.; MADER, C. L. A scanning electron microscopic evaluation of four root canal irrigation regimens. J. Endod., Chicago, v. 13, n. 4, p. 147-57, 1987.

BECHELLI, C.; ORLANDI, S. Z.; COLAFRANCESCHI, M. Scanning electron microscope study on the efficacy of root canal wall debridament of hand versus Lightspeed instrumentation Int. Endod. J., Oxford, n. 3, p. 484-493, 1999.

BERTRAND, M. F.; PIZZARDINI, M. M.; MÉDIONI, E.; ROCCA, J. P.The removal of smear layer using Quantec system. Astudy using the scanning electron microscope. Int.Endod. J., Oxford, v. 32, p. 217-224, 1999.

BLUM, J. Y.; ABADIE, M. J. Study of the Nd: YAG laser. Effect on canal cleanliness. J. Endod., Chicago, v. 23, n.11, p. 669-75, 1997. 
BRAMANTE, C. M.; BERBERT, A.; BORGES, R. P. THE methodology goes evaluation of root channel instrumentation. J. Endod., Chicago, v. 13, n.5, p. 243-245, May 1987.

BRIlliant, J. D.; CHRIStiE, W. D. The taste of endodontics. J. Acad. Gen. Dent., Chicago, v. 23, n. 3, p. 233-45, 1975.

BRYANT, S. T.; THOMPSON, S. A.; ALOMARI, M. A.; DUMMER, P. M. Shaping ability of Profile rotary nickel-titanium instruments with ISO sized tips in simulated root canals. Part 1. Int Endod. J., Oxford, v. 31, n. 4, p. 275-281, 1998a.

BRYANT, S. T.; THOMPSON, S. A.; ALOMARI, M. A.; DUMMER, P. M. Shaping ability of Profile rotatory nickel-titanium instruments with ISO sized tips in simulated root canals. Part 2. Int. Endod. J., Oxford, v. 31, n. 4, p. 282-289, 1998 b.

BRUGNERA-JÚNIOR, A.; PINHEIRO, A. L. B. Lasers na Odontologia moderna. São Paulo: Pancast, 1998.

BRUGNERA-JÚNIOR, A. Estudo da ação dos lasers er:yag e nd:yag sobre a permeabilidade da dentina das paredes dos canais radiculares instrumentados. 2001. Dissertação (Doutorado)-Faculdade de Odontologia de Ribeirão Preto, Universidade de São Paulo, Ribeirão Preto.

BRUGNERA-JÚNIOR, A.; ROE, I. M.; GUERISOLI, D. M. Z.; BARBIZAM, J. V. B.; PÉCORA, J. D. "SEM evaluation of smear layer removal by Er: YAG laser in root canals," SPIE, Bellingham, v. 4610, p. 148-53, 2002.

BUCHANAN, L. S. The standardized-taper root canal preparation - Part 1. Concepts for variably tapered shaping instruments. Int. Endod. J., Oxford, v.33, p. 516-529, 2000. 
BUCHANAN, L. S. The standardized-taper root canal preparation - Part 2. File selection and safe handpiece - driven file use. Int. Endod. J., Oxford, v. 34, p. 63-71, 2001.

BURKES, E. J.; HOKE, J.; GOMES; E.; WOLBARSHT, M. Wet versus dry enamel ablation by Er: YAG laser. J. Prosthet. Dent., St. Louis, v. 67, p. 847-51, 1992.

CALlahan, J. R. Sulfuric acid for opening root canals. Dent. Cosmos, Philadelphia, v. 36, n. 12, p.957-9, 1894.

CALT, S.; SERPER, A. Smear layer removal by EGTA. J. Endod., Chicago, v. 26, n. 8, p. 459-461, 2000.

CAMARGO, S. C. C.; GAVINI, G.; EDUARDO, C. P.; AUN, C. E.; COIL, J. M. An in vitro evaluation of Er: YAG laser irradiation in apicoectomy and retrofilling cavity preparation, compared to two different techniques: an without observation. SPIE, Bellingham, v. 3248, p. 25-26, January, 1998.

CAMPOS, G. M. Programa estatístico GMC 8.0. Disponível em: http://www.forp.usp.br/restauradora/gmc/gmc.html, Acesso em 17 jul. de 2002.

CAMPS, J. J.; PERTOT, W. J.; LEVALLOIS, B. Relationship between file size and stiffness of nickel-titanium instruments. Endod. Dent. Traumatol. Copenhagen, v. 11, n. 6, p. 270-73, Dec, 1995.

CASTRO, F.C.. Avaliação do efeito dos raios laser Er: YAG, $\mathrm{CO}_{2}$ e Nd: YAG sobre a permeabilidade dentinária apical após apicectomia 2002. 84p. Dissertação (Mestrado)Faculdade de Odontologia de Ribeirão Preto, Universidade de São Paulo, Ribeirão Preto.

CECCHINI, S. C.; ZEZELL, D. M.; BACHMANN, L.; PINOTTI, M.; NOGUEIRA, G. E. C.; EDUARDO, C. P. Thermal effects during in vitro intra-canal application of Er: YAG laser. In: International Congress on Lasers in Dentistry, 6, Maui, Hawaii, 1998.

CHAN, A. W. K.; CHEUNG, G. S. P. The comparison of stainless steel and nickel-titanium K-files in curved root canals. Int. Endod. J., Oxford, v. 29, n. 6, p. 370-375, Nov. 1996. 
CHAPMAN, C. E.; COLLE, J. G.; BEAGRIE, G. S. A preliminary report on the correlation between apical infection and instrumentation in endodontics. J. Br. Endod. Soc., London, v. 2, p. 7-11, 1968.

CHEUNG, G. S. P.; STOCK, C. J. R. In vitro cleaning ability of root canal irrigants with and without endosonics. Int. Endod. J., Oxford, v. 26, p. 334-343, 1993.

CLEM, W. H. Endodontics: the adolescent patient. Dent. Clin. North. Am., Philadelphia, v. 13, n. 2, p. 483-93, 1969.

CIVJAN, S.; HUGET, E.F.; De SIMON, L.B. Potential applications of certain nickel-titanium (nitinol) alloys. J. Dent. Res. Chicago, v. 54, n. 1, p. 89-96, 1975.

COHEN, S.; BURNS, R.C. Pathways of the pulp. 7th ed. St. Louis: Mosby , 1998.

COBB, I. M.; ROSSMAN, J. A.; SPENCER, P. The effects of $\mathrm{CO}_{2}$, Nd: YAG laser with and without surface coolant on tooth root surfaces. J. Clin. Periodontol., Copenhagen, v. 24, n. 9, p. 595-602, 1997.

COOLIDGE, E. D. Anatomy of the root apex in relation to treatment problems. J. Am. Dent. Assoc., Chicago, v. 17, n. 2, p. 1456-65, Aug.1929.

CUNNINGHAN, W. T.; BALEKJIAN, A. Y. Effect of temperature on collagen-dissolving ability of sodium hypochlorite endodontic irrigant. Oral Surg. Oral Med. Oral Pathol., St. Louis, v. 49, n. 2, p. 175-177, 1980.

CUNNINGHAN, W. T.; JOSEPH, S. W. Effect of temperature on the bactericidal action of sodium hupochlorite endodontic irrigant. Oral Surg. Oral Med. Oral Pathol., St. Louis, v. 50, n. 6, p. 569-571, Dec. 1980. 
DAVIS, S. R.; BRAYTON, S. M.; GOLDMAN, M. The morphology of the prepared root canal: a study utilizing injectable silicone. Oral Surg. Oral Med. Oral Pathol., St. Louis, v. 34, n. 4, p. 642-8, Oct. 1972.

DE DEUS, Q. D. Endodontia. 4. ed. Rio de Janeiro: Medsi, 1986.

DE DEUS, Q. D. Endodontia. 5. ed. Rio de Janeiro: Medsi, 1992.

DOSTÁlOVÁ, T.; JELÍNKOVÁ, H.; KREJSA, O.; HAMAL, K.; KUBELKA, J.; PROCHÁZKA, S.; HIMMLOVÁ, L. Dentin and pulp response to Er: YAG laser ablation: a preliminary evaluation of human teeth. J. Clin. Laser Med. Surg., New York, v.15, n.3, p.117-121, 1997.

EBIHARA, A.; WADACHI, R.; SEKINE, Y.; TAKEDA, A.; SUDA, H. Application of Er: YAG laser to apicoectomy. 6TH International Congress on Lasers in Dentistry, Maui, v. 28, n. 30, p.131-5, July 1998.

ESPOSITO, P. T.; CUNNINGHAM, C. J. A comparison of canal preparation with nickeltitanium and stainless steel instruments. J. Endod., Chicago, v. 21, n. 4, p. 173-175, Apr. 1995.

ESTRELA, C., FIGUEIREDO, J. A. P., Endodontia: princípios biológicos e mecânicos.São Paulo: Artes Médicas, 1999.

EVANS, T.; SIMON, J. H. S. Evaluation of the apical seal produced by infect thermoplasticized gutta-percha in the absence of smear layer and root canal sealer. J. Endod., Chicago, v. 12, p. 101-7, 1986.

EVANS, G. SPEIGHT, P. M. GULABIVALA, K. The influence of preparation technique and sodium hipochlorite on removal of pulp and presenting from root canals of posteriors teeth. Int. Endod. J., Oxford, v. 34, p. 322-330, 2001. 
FEGAN, S. E.; STEIMAN, H. R. Comparative evaluation of the antibacterial effects of intracanal Nd: YAG laser irradiation: an in vitro study. J. Endod., Chicago, v. 21, n. 8, p. 415$417,1995$.

FOGEL, H.M.; PASHLEY, D.H. Dentin permeability: effects of endodontic procedures on root slabs. J. Endod., Chicago, v. 16, n. 9, p. 442-5, 1990.

GARBEROGLIO, R.; BECCE, C. Smear layer removal by root canal irrigants. A comparative scanning microscopic study. Oral Surg. Oral Med. Oral Pathol., St. Louis, v. 78, n. 5, p. 359-67, 1994.

GAMBARINI, G. Shaping and cleaning the root canal system: a scanning electron microscopic evaluation of a new instrumentation and irrigation technique. J. Endod., Chicago, v. 25, n. 12, p. 800-803, 1999.

GETTLEMAN, B. H.; MESSER, H. H.; EL DEEB, M. E. Adhesion of sealer cements to dentin with and without the smear layer. J. Endod., Chicago, v. 17, n. 1, p. 15-20, Jan. 1991.

GLOSSEN, C. R.; HALlER, R. H.; DOVE, S. B.; DEL RIO, C. E. A comparison of root canal preparations using Ni-Ti hand, Ni-Ti engine-driven, and K-flex endodontic instruments. J. Endod., Chicago, v. 21, n. 3, p. 146-151, 1995.

GOLDBERG, F. ABRAMOVICH, A. Analysis of the effect of EDTAC on the root canal. J. Endod., Chicago, v. 3, n. 3, p. 101-5, Mar. 1977.

GOLDMAN, L., GRAY, J.A., GOLDMAN, J., GOLDMAN, B., MEYER, R. Effects of laser impacts on teeth. J. Am. Dent. Assoc., Chicago, v. 70, p. 601-6, 1965.

GORDON, T. M.; DAMATO, D.; CHRISTNER, P. Solvent effect of various dilutions of sodium hypochlorite on vital and necrotic tissue. J. Endod., Chicago, v. 7, n. 10, p. 466-469, Oct. 1981.

GROSSMAN, L. I.; MEIMAN, B. W. Solution of pulp tissue by chemical agents. J. Am. Dent. Assoc., Chicago, v. 28, n. 2, p. 223-225, Feb. 1941.

GROSSMAN, L. I. Irrigation of root canals. J. Am. Dent. Assoc., Chicago, v. 30, n. 13, p. 1915-1917, Dec. 1943. 
GROSSMAN, L. I. Tratamento dos canais radiculares. 2.ed., Rio de Janeiro: Atheneu, 1956.

GROSSMAN, L. I. Endodontic treatment of pulpless teeth. J. Am. Dent. Assoc., Chicago, v. 61, n. 6, p. 671-676, Dec. 1960.

GUERISOLI, D. M. Z.; SOUSA NETO, M. D.; PÉCORA, J. D. Ação do hipoclorito de sódio em diversas concentrações sobre a estrutura dentinária. Rev. Odont. UNAERP, Ribeirão Preto, v. 1, n. 1, p. 7-11, 1998.

GUERISOLI, D. M. Z. Estudo, por meio da microscopia eletrônica de varredura, da remoção da "smear layer" dos canais radiculares após aplicação de diferentes agentes quelantes e do laser Er: YAG. 2002. 76p. Dissertação (Mestrado)-Faculdade de Odontologia de Ribeirão Preto, Universidade de São Paulo, Ribeirão Preto.

GUERISOLI, D. M. Z.; MARCHESAN, M. A.; WALMSLEY, A. D.; LUMLEY, P. J.; PÉCORA, J. D. Evaluation of smear layer removal by EDTA and sodium hypochlorite with ultrasonic agitation. Int. Endod. J. Oxford, v.35, n. 5, p. 418-21, May.,2002.

GUTIÉRREZ, J. H. \& CARCIA,J. Microscopic and microscopic investigation on results of mechanical preparation of root canals. Oral Surg. Oral Med. Oral Pathol., St. Louis, v. 25, n. 1, p. 108-15, Jan. 1968.

HAIKEL, T. Cutting Efficiency of nickel-titanium endodontic instruments and the effect of sodium hypoclorite treatment. J. Endod. Chicago, v. 24, n. 11, p. 736-39, Nov. 1998.

HALL, E. M. The mechanics of root canal treatment. J. Am. Dent. Assoc., Chicago,v. 17, n. 1, p. 88-112, 1930.

HAND, R. E.; SMITH, M. L.; HARRISON, J. W. Analysis of the effect of dilution on the necrotic tissue dissolution property of sodium hypochlorite. J. Endod., Chicago, v. 4, n. 2, p. 60-64, Feb. 1978.

HARASHIMA, T.; TAKEDA, F. H.; ZHANG, C.; KIMURA, Y.; MATSUMOTO, K. Effects of argon laser irradiation on instrumented root canal walls. End. Dent. Traumatol., Copenhagen, v. 18, p. 12-18, 1998. 
HATA, G.; HAYAMI, S.; WEINE, F. S.; TODA, T. Effectiveness of oxidative potencial water as a root canal irrigant. Int. Endod. J., Oxford, v. 34, p. 308-317, 2001.

HEARD, F.; WALTON, R. E. Scanning electron microscope study comparing four root canal preparation techniques in small curved canal. J. Endod., Chicago, v. 30, n. 5, p. 323-31, 1997.

HIBST, R.; KELLER, U. Experimental studies of the application of the Er: YAG laser on dental hard substancies: I. Measurement of the ablation rate. Lasers Surg. Med., New York, v. 9, p. 338-344, 1989.

HIMEL, V. T.; AHMED, K. M.; WOOD, D. M.; ALHADAINY, H. A. An evaluation of nitinol and stainless steel files used by dental students during a laboratory proficiency exam. Oral Surg. Oral Méd. Oral Pathol., St. Louis, v. 79, n. 2, p. 232-237, Feb. 1995.

HOLLAND, R.; SOUZA, V.; OTOBONI FILHO, J. A.; NERY, M. J.; BERNABE, P. F. E.; MELLO, W. Técnicas mistas de preparo do canal radicular. Rev. Paul. Odontol., São Paulo, v. 13, n. 4, p. 17-23, 1991.

UNIVERSIDADE DE SÃO PAULO. Faculdade de Odontologia de Ribeirão Preto. Homepage. Disponível em: http://www.forp.usp.br/restauradora/solu.html Acesso em 16 sep. 2001.

HÜLSMANN, M.; RÜMMELIN, C.; SCHÄFERS, F. Root canal cleanliness after preparation with different endodontic handpieces and hand instruments: A comparative SEM investigation. J. Endod., Chicago, v. 23, n. 5, p. 301-6, 1997.

ISRAEL, M.; COBB, C. M.; ROSSMAN, J. A.; SPENCER, P. The effects of CO2, Nd: YAG and Er:YAG lasers with and without surface coolant on tooth surfaces. An in vitro study. J Clin. Periodontol., Copenhagen, v. 24, n. 9, p. 595-602, 1997.

KELLER, U., e HIBST, R. Experimental studies of the application of Er: YAG laser on dental hard substances: II. Light microscopic and SEM investigations. Laser Surg. Med., New York, v. 9, n. 345-351, 1989.

KIMURA, Y.; YONAGA, K.; YOKOYAMA, K.; KINOSHITA, J.; OGATA, Y.; MATSUMOTO, K. Root surface temperature increase during Er: YAG laser irradiation of root canals. J. Endod., Chicago, v. 28, n. 2, p. 76-8, 2002. 
KORZEN, B. H. Quantec series 2000 graduating Tapers Technique for endodontic Canal Preparation. Oral Health., Don Mills, p. 15-18, Dec., 1996.

KOSKINEN, K. P.; STENVALL, H.; UITTO, V. J. Dissolution of bovine pulp tissue by endodontic solutions. Scand. J. Dent. Res, Copenhagen, v. 88, n. 5, p. 406-411, 1980.

KUMAZAKI, M. Removal of hardy dental tissue (cavity preparation)with the Er: YAG laser. 6TH International Congress on Lasers in Dentistry, Maui, v. 28, n. 30, p. 12-6, july, 1998.

KUTTLER, Y. Microscopic investigation of root apexes. J. Am. Dent. Assoc., Chicago, v. 50, n. 5, p. 544-52, 1955.

LEONARDO, M. R. Novos conceitos no preparo de canais radiculares atresiados e curvos de molares. Rev. Assoc. Paul. Cir. Dent., São Paulo, v. 51, n. 3, p. 289-290, mai./jun. 1997.

LEONARDO, M. R. BONETTI FILHO, I., LEONARDO, R. Instrumentos Edodônticos fabricados com liga de níquel-titânio. In: LEONARDO, M. R., LEAL, J. M. Endodontia. Tratamento de canais Radiculares. 3.ed., São Paulo: Panamericama, 1998, p.465-489.

LEONARDO, M. R.; LEONARDO, R. T. Sistemas rotatórios em Endodontia instrumentos de níquel-titânio. São Paulo: Artes médicas, 2002.

LIU, H. C.; LIN, C. P.; LAN, W. H. Sealing depth of Nd: YAG laser on human dentinal tubules. J. Endod, Chicago, v. 23, n. 11, p. 691-693, 1997.

LOPES, H. P., SIQUEIRA JR, F. Endodontia: biologia e técnica. Rio de Janeiro: Medsi, 1999, p.279-318.

LUMLEY, P. J. Cleaning efficacy of two apical preparation regimens following shaping with hand files of greater taper. Int. Endod. J., Oxford, v. 33, p. 262-2, 2000.

MACHIDA, T.; WILDER-SMITH, P.; ARRASTIA, A. M.; LIAW, L. H. L.; BERNS, M. W. Root canal preparation using second harmonic KTP: YAG laser: a thermographic and scanning electron microscopic study. J Endod, Chicago, v. 21, n. 2, p. 88-91, 1995. 
MADER, C.L.; BAUMGARTNER, C.; PETERS, D.D. Scanning electron microscopic investigation of the smeared layer on root canal walls. J. Endod., Chicago, v. 10. n. 10, p. 477-83, 1984.

MAIMAN, T. H. Simulated optical radiation in ruby. NATURE, London, v. 187, p. 493-494, 1960.

MACHTOU, P. L. Irrigation en endodontie. Actual. Odontostomatol., Paris, v. 34, n. 131, p. 387-394, Sept. 1980.

McSPADDEN, J. T. Advanced geometries in endodontic microfiles: The rationale. Chattanooga, The NT Company, 1996.

MARSHALL, F. J.; MASSLER, M.; DUTE, H. L. Effects of endodontic treatment of root dentine. Oral Surg. Oral Méd. Oral Pathol., St. Louis, v. 13, n. 2, p. 208-233, 1960.

MARCHESAN, M. A.; SOUZA, R. A.; GUERIZOLI, D. M. Z.; SILVA, R. S.; PÉCORA, J. D. Análise de algumas propriedades físico-químicas das águas sanitárias encontradas no mercado brasileiro. Rev. Brás. Odontol., Rio de Janeiro, v. 55, n. 5, p. 301-3, 1998.

MARCHESAN, M. A. Análise histológica da capacidade de limpeza promovida pela instrumentação rotatória, associada à soluções irrigantes, com limas de níquel-titânio em canais radiculares com achatamento mésio-distal. 2001. 44 p. Monografia (Especialização), Curso de Odontologia da Universidade de Ribeirão Preto, Ribeirão Preto.

MARCHESAN, M.A. Estudo por meio da microscopia óptica, do efeito da irradiação do laser Er: YAG sobre a limpeza dos canais radiculares. 2002. 70p. Dissertação (Mestrado)Faculdade de Odontologia de Ribeirão Preto, Universidade de São Paulo, Ribeirão Preto.

MARTIN, H. A telescop technic for endodontics. J. Dist. Columbia Dent. Soc., Washington, v. 49, n. 2, p. 12-19, 1974.

MARTIN, H.; SPRING, S. Quantitative bactericidal effectiveness of an old and a new endodontic irrigant. J. Endod., Chicago, v. 1, n. 5, p. 164-167, may 1975.

McCOMB, D.; SMITH, D. C. A preliminary scanning electron microscopic study of root canals after endodontic procedures. J. Endod., Chicago, v. 1, n. 7, p. 238-42, July 1975. 
MELO, L. L., SIDNEY, G. B. Novas técnicas com instrumentação endodôntica: manual e mecânica. In: GONÇALVES, E.A.; FELER, C. Atualização na Clínica Odontológica. São Paulo: Artes Médicas, 1998, p.167-200.

MOONIK, R. M.; DORN, S. O.; FELDMAN, M. J.; LEVEY,M.; BORDEN, B. O. Efficacy of biomechanical instrurnentation: a scanning electron microscopic study. J. Endod., Chicago, v. 2, n. 9, p. 261-6, Sept 1976.

MOORER, W. R.; WESSELINK, P. R. Factors promoting the tissue dissolving capability of sodium hypochlorite. Int. Endod. J., Oxford, v. 15, n. 4, p. 187-196, Oct. 1882.

MORAES, S. H., ARAGÃO, E. M., HECK, A. R. Preparo dos canais radiculares com sistema Quantec. Jornal Brasileiro de Clínica \& Estética em Odontologia. Curitiba, v. 15, n. 3, p. 71-73, 1999.

MOSHONOV, J.; SION, A.; KASIRER, J.; ROTSTEIN, I.; STABHOLTZ, A. Efficacy of argon laser irradiation in removing intracanal debris. Oral Surg. Oral Méd. Oral Pathol., St. Louis, v. 79, n. 2, p. 221-225, 1995.

MOURA, M. S.. Estudo in vitro do efeito antimicrobiano do laser Er: YAG em canais radiculares infectados. 2003. 100p. Dissertação (Mestrado)-Faculdade de Odontologia de Ribeirão Preto, Universidade de São Paulo, Ribeirão Preto.

MUllanEY, T. P. Instrumentation of finely curved canals. Dent. Clin. North. Am., Philadelphia, v. 23, n. 4, p. 575-92, 1979.

NERY, M. J; HOLLAND, R; SOUZA, V. de Eficiência de diferentes técnicas de irrigação e soluções irrigadoras na remoção de detritos do interior dos canais radiculares. Rev. Assoc. Paul. Cir. Dent, São Paulo, v. 3, n. 1, p. 21-27, 1982. 
NIKIFORUK, G.; SREEBNY, L. Demineralization of hand tissues by organic chelating agents at neutral pH. J. Dent. Res. Chicago, v. 32, n. 6, p. 859-67, Dec. 1953.

ØSTBY, N. B. Chelation in root canal therapy. Ethylenediamine tetra-acetic acid for cleaning and widening of root canal. Odontol. Tidskr., Göteborg, v. 65, n. 2, p. 3-11, 1957.

PÉCORA, J. D. Contribuição ao estudo da permeabilidade dentinária radicular. Apresentação de um método histoquímico e análise morfométrica. 1985. 98p. Dissertação (Mestrado)-Faculdade de Odontologia de Ribeirão Preto, Universidade de São Paulo, Ribeirão Preto.

PÉCORA, J. D. Efeito das soluções de Dakin e de EDTA, isoladas, alternadas e misturadas, sobre a permeabilidade da dentina radicular. 1992. 148p Tese de LivreDocente-Faculdade de Odontologia de Ribeirão Preto, Universidade de São Paulo, Ribeirão Preto.

PÉCORA, J. D.; SOUZA NETO, M. D.; SAQUY, P. C.; SILVA, R. G.; CRUZ FILHO, A. M. Effect of Dakin's and EDTA solutions on dentin permeability after instrumentation and Er: YAG laser application. Brazil. Dent. J., Ribeirão Preto, v.4, n. 2, p. 79-84, 1993.

PÉCORA, J. D.; BRUGNERA JÚNIOR, A.; CUSSIOLI, A. L.; SILVA, R .S.; ZANIN, F. Dentin root canal wall permeability evaluation after instrumentation and Er: YAG laser applicaton. In: ANNUAL MEETING AMERICAN SOCIETY FOR LASER MEDICINE AND SURGERY, 19, Orlando, 1999. Abstract. Orlando, 1999.

PÉCORA, J. D.; BRUGNERA JÚNIOR. A.; ZANIN, F.; SILVA, R. S; MARCHESAN, M. A.; DAGHASTANLI, N. A. Effect of energy (J) on temperature changes at apical root surface when using Er: YAG laser to enlarge root canals. SPIE, Bellingham, v. 3910, p. 90-4, 2000a. 
PÉCORA, J. D.; BRUGNERA JÚNIOR., A.; CUSSIOLI, A. L.; SILVA, R. S. Evaluation of dentin root canal permeability after instrumentation and Er: YAG laser application. Lasers Surg. Med., New York, v. 26, n. 3, p. 277-81, 2000 b.

PÉCORA, J. D. CAPELLI, A.; SEIXAS, F. H.; MARCHESAN, M.A.; GUERISOLI, D. M. Z. Biomecânica Rotatória: Realidade ou Futuro? Rev. Assoc. Paul. Cir. Dent., São Paulo, v. 56, p. 4-6, jun.2002. Suplemento.

PEREZ, F.; CALAS, P.; ROCHD, T. Effect of dentin treatment on in vitro root tubule bacterial invasion. Oral Surg. Oral Med. Oral Pathol, St. Louis, v. 82, n. 4, p. 446-451, 1996.

PETERS, O.A. \& BARBAKOW, F. Effects of irrigation on Debris and Smear layer on Canal Walls Prepared by Two Rotary Techniques: A Scanning Electron Microscope. J. Endod., Chicago, v. 11, n. 5, p. 203-11, 1985.

PETERS, O. A.; BARBAKOW, F. Effects of irrigation on debris and smear layer on canal walls prepared by two rotary techniques: a scanning electron microspic study. J. Endod., Chicago, v. 26, n. 1, p. 6-10, 2000.

PINEDA, F., KUTTLER, S. Una nueva solución para chegar al apice: el RBS. Blvd. Interlornas \# 14-202, Col. San Fernando la Herradura, 52760. México, 4p., 1997.

PICOLI, F. Estudo "in vitro" do efeito da aplicação do laser Er: YAG e da solução de EDTAC na superfície dentinária, sobre a adesividade de diferentes cimentos endodônticos contendo hidróxido de cálcio. 2001. 88p. Dissertação (Mestrado)-Faculdade de Odontologia de Ribeirão Preto, Universidade de São Paulo, Ribeirão Preto.

ROBAZZA, C. R. C. Contribuição "in vitro" da permeabilidade dentinária radicular quando do emprego de algumas substâncias de uso endodôntico. 1973. Tese (Doutorado)Faculdade de Odontologia e Farmácia de Ribeirão Preto, Universidade de São Paulo, Ribeirão Preto.

REDDY, S. A.; HICKS, M. L. Apical extrusion of debris using two hand and two rotary instrumentation techniques. J. Endod., Chicago, v. 24, n. 3, p. 180-183, Mar. 1998. 
ROANE, J. B.; SABALA, C. L.; DUNCANSON JÚNIOR., M. G. El concepto de fuerza balanceada para la instrumentacion de conductos curvos. J. Endod., Chicago, v. 11, n. 5, p. 203-11, 1985.

SAHLI, C. C.; AGUADÉ, E. B.; JIMENO, E. B. A comparison of bending and torsional properties of K-files manufactured with different metallic alloys. Int. Endod. J., Oxford, v. 29, n. 3, p. 185-189, May 1996.

SAUNDERS, E. M.; SAUNDERS, W. P. Long-term coronal leakage of JS Quickfill root fillings with Sealapex and Apexit sealers. Endod. Dent. Traumatol., Copenhagen, v. 11, n. 4, p. 181-185, 1995.

SAQUY, P. C. Avaliação da capacidade quelante do EDTA e da associação EDTA + solução de Dakin, por métodos químicos e pela análise da microdureza da dentina. 1991. 95p. Tese (Doutorado)-Faculdade de Odontologia de Ribeirão Preto, Universidade de São Paulo, Ribeirão Preto.

SAVIOLI, R. N.; COSTA, W. F.; SAQUY, P. C.; ANTONIAZZI, J. H.; PÉCORA, J. D. Estudo comparativo entre o hipoclorito de sódio e o ácido cítrico na capacidade de limpeza do canal radicular. Rev. Odonto. USP, São Paulo, v. 7, n. 4, p. 273-277, out./dez. 1993.

SCHILDER, H. Cleaning and shaping the root canal. Dent. Clin. North. Am., Philadelphia, v. 18, p. 269-96, 1974.

SCHRADER, M.; ACKERMANN, M.; BARBAKOW, F. Step-by-step description of a rotary root canal preparation technique. Int. Endod. J., Oxford, v. 32, p. 312-320, 1999.

SEIXAS, F.H. Utilização do laser na Endodontia. Ribeirão Preto, 2000, 37p. Monografia (Especialização)-Faculdade de Odontologia de Ribeirão Preto, Universidade de Ribeirão Preto, Ribeirão Preto.

SEN, B. H. The smear layer: A phennomenon root canal therapy. Int. Endod. J. Oxford, v. 28, p. 141-8, 1995. 
SENIA, E. S.; MARSHALL F. J.; ROSEN, S. The solvent action of sodiun hypochlorite on pulp tissue of extracted teeth. Oral Surg. Oral Med. Oral Pathol., St. Louis, v. 31, n. 1, p. 96-103, Jan. 1971.

SERENE, T. P.; ADAMS, J. D.; SAXENA, A. Nickel-Titanium instruments. Applications in Endodontic. St. Louis: Missouri, USA: Ishiyaku Euroamerica,, 1995.

SELTZER, S.; SOLTANOFF, W.; BENDER, I. B.; ZIONTZ, M. Biologic aspects of endodontics. 1. Histologic observations of the anatomy and morphology of root apices and surrounding structures. Oral Surg. Oral Med. Oral Pathol., St. Louis, v.22, n. 3, p. 375-85, Sept. 1966.

SHIH, M.; MARSHALL, F. J.; ROSEN, S. The bactericidal efficiency of $\mathrm{NaOCl}$ as an endodontic irrigant. Oral Surg. Oral Med. Oral Pathol., St. Louis, v. 29, n. 4, p. 613-617, Apr. 1970.

SHOJI, S.; HARIU, H.; HORIUCHI, H.Canal enlargement by Er: YAG laser using a cone shaped irradiation tip. J. Endod., Chicago, v. 26, n. 8, p. 454-8, 2000.

SIQUEIRA, J.F. Tratamento das infecções endodônticas. 1. ed., Rio de Janeiro: Ed. Medsi, 1997.

SIQUEIRA, J. F.; ARAÚJO, M. C.; GARCIA, P. F.; FRAGA, R. C.; DANTAS, C. J. Histological evaluation of the effectiveness of five instrumentation techniques for cleaning the apical third of root canals. J. Endod., Chicago, v. 23, n. 8, p. 499-502, 1997.

SILVA, S.A.H. Avaliação “in vitro" da infiltração apical em dentes submetidos à apicectomia com e sem o uso de laser Er: YAG e retrobturados com diferentes materiais. 2003. 113p. Dissertação (Mestrado)-Faculdade de Odontologia de Ribeirão Preto, Universidade de São Paulo, Ribeirão Preto. 
SÓ, M. V.; CEMIM, A.; PEREIRA, E. P.; IRALA, L. E. D. Tissue dissolution ability of sodium hypochlorite from different manufacturers. Braz. Endod. J., Goiânia, v. 2, n. 2, p. 3335, 1997.

SOUZA, F.D. Avaliação da infiltração marginal coronária de canais radiculares obturados após o uso de laser Er: YAG e de EDTA no preparo biomecânico e aplicação de película seladora. 2003. 152p. Dissertação (Mestrado)-Faculdade de Odontologia de Ribeirão Preto, Universidade de São Paulo, Ribeirão Preto.

SPANÓ, J.C.E. Estudo in vitro das propriedades físico-químicas das soluções de hipoclorito de sódio, em diferentes concentrações, antes e após a dissolução de tecido pulpar bovino. 1999. 96p. Dissertação (Mestrado)-Faculdade de Odontologia de Ribeirão Preto, Universidade de São Paulo, Ribeirão Preto.

SPANÓ, J. C. E; BARBIN, E. L.; SANTOS, T. C.; GUIMARÃES, L. F.; PÉCORA, J. D. Solvent action of Sodium Hypochlorite on bovine pulp and physico-chemical properties of resulting liquid, Braz. Dent. J.. Ribeirão Preto, v. 12, p. 154-79, 2001.

STERN, R. H., SOGANNAES, R. F. Laser beam effect on dental hard tissues. J. Dent. Res., Chicago, v. 43, p. 873, 1964.

STEWART, G. G; KAPSIMALS, P. RAPPAPORT, H. Edta and urea peroxide for root canal preparation. J. Am. Dent. Assoc., Chicago, v. 78, n. 2, p. 335-8, 1969.

TAKAHASHI, K.; MATSUOKA, E.; KIMURA, Y.; MATSUMOTO, K. The morphological study of root canal walls with Er: YAG laser . J. Jpn. Endod. Assoc., Tókyo, v. 17, p. 197203, 1996.

TAKEDA, F. H.; HARASHIMA, T.; KIMURA, Y.; MATSUMOTO, K. Efficacy of Er:YAG laser irradiation in removing debris and smear layer on root canal walls. J. Endod., Chicago, v. 24, n. 8, p. 548-551, 1998a.

TAKEDA, F. H.; HARASHIMA, T.; KIMURA, Y.; MATSUMOTO, K. Comparative study about the removal of smear layer by three types of Lasers devices. J. Clin. Laser. Med. Surg., New York, v. 16, n. 2, p. 117-122, 1998 b. 
TAKEDA, F. H.; HARASHIMA, T.; KIMURA, Y.; MATSUMOTO, K. Effect of Er:YAG laser treatment on the root canal walls of human teeth: an SEM study. Endod. Dent. Traumatol., Copenhagen, v. 14, n. 6, p. 270-273, 1998 c.

TAKEDA, F. H.; HARASHIMA, T.; KIMURA, Y.; MATSUMOTO, K. A comparative study of the removal of smear layer by three endodontic irrigants and two types of laser. Int. Endod. J., Oxford, v. 32, n. 1, p. 32-9, 1999.

TANJI, E. Y.; MATSUMOTO, K.; EDUARDO, C. P. Scanning electron microscopic observations of dentin surface conditioned with the Er: YAG laser. Deuts Gesellschaft Laser Newsletter, Berlin, v.8, p.6, Jan/Feb 1997 (Edição congresso).

TEPEL, J.; SCHAFFER, E.; HOPPE, W. Proprieties of endodontic hand instruments used in rotatory motion. Part 1: cutting efficiency. J. Endod., Chicago, v. 21, n. 8, p. 418-21, Aug., 1995.

THÉ, S. D. The solvent action of sodium hupochlorite on fixed and unfixed necrotic tissue. Oral Surg. Oral Med. Oral Pathol., St. Louis, v. 47, n. 6, p. 558-561, 1979.

THOMPSON, S. A.; DUMMER, P. M. Shaping ability of ProFile .04 taper series 29 rotary nickel-titanium instruments in simulated root canals: Part 1. Int. Endod. J., Oxford, v. 30, n. 1, p. 1-7, 1997a.

THOMPSON, S. A.; DUMMER, P. M. Shaping ability of ProFile .04 taper series 29 rotary nickel-titanium instruments in simulated root canals: Part 2. Int. Endod. J., Oxford, v. 30, n. 1, p. 8-15, 1997 b.

TORABINEJADE, M.; KHADEMI, A. A.; BABAGOLI, J.; CHO, Y.; JOHNSON, W. B.; BOZHILOV, K.; KIM, J.; SHABAHANG, S. A new solution for the removal of the smear layer. J. Endod. Chicago, v. 29, n. 3, p. 170-5, Mar., 2003a.

TORABINEJADE, M.; CHO, Y.; KHADEMI, A.A.; BAKLAND, L.K.; SHABAHANG, S. The effect of various concentrations of sidium hypochlorite on ability of MTAD to remove the smear layer. J. Endod., Chicago, v. 29, n. 4, p. 233-9, Apr., 2003 b. 
TREPAGNIER, C. M.; MADDEN, R. M.; LAZZARI, E. P. Quantitative study of sodium hypochlorite as an in vitro endodontic irrigant. J. Endod., Chicago, v. 3, n. 5, p. 194-196, May 1977.

VALLI, K. S.; LATA, D. A.; JAGDISH, S. An "in vitro" SEM comparative study of debridemente ability of K-Files and Canal Master. Indian J. Dent. Res., Ahmedabad, v. 7, n. 4, p. 128-34, 1996.

VISURI, S. R.; WALSH, J. T.; WIGDOR, H. A. Erbium laser ablation of dental hard tissue: effect of water-cooling. Lasers Surg. Med., New York, v. 18, p. 294-300, 1996.

VANSAN, L.P. - Estudo comparativo "in vitro" da quantidade de material extruído apicalmente durante a instrumentação dos canais radiculares. 1993. 65p. Dissertação (Doutorado)-Faculdade de Odontologia de Ribeirão Preto, Universidade de São Paulo, Ribeirão Preto.

WALIA, H.; BRANTLEY, W.A.; GERSTEIN, H. An initial investigation of the bending and torsional properties of nitinol root canal files. J. Endod., Chicago, v. 14, n. 7, p. 346-51, 1988.

WALKer, A. A definite and dependable therapy for pulpless teeth. J. Am. Dent. Assoc., Chicago, v. 23, n. 2, p. 1418-25, Aug. 1936.

WALTON, R. E. Histologic evaluation of different methods of enlarging the pulp canal space. J. Endod., Chicago, v. 2, n. 10, p. 304-11, 1976.

WEINE, F. S; HEALEY, H. J; GERSTEIN, H; EVANSON, L. Pre-curved files and incremental instrumentation for root canal enlargement. J. Can. Dent. Assoc., Ottawa, v. 36, n. 4, p. 155-7, 1970.

WEINE, F. S. Endodontic therapy. Saint Louis: Mosby, 1972. 
WEINE, F. S. Endodontic therapy. 3. ed. Saint Louis: Mosby, 1982.

WENNBERG, A. Biological evaluation of root canal antiseptics using in vitro and in vivo methods. Scand. J. Dent. Res., Copenhagen, v. 88, n. 1, p. 46-56, Feb. 1980.

WIGDOR, W.; ELLIOT, A. B. T.; ASHRAFI, S.; JOSEPH, T. The effect of lasers on dental hard tissues. J. Am. Dent. Assoc., Chicago, v. 124, p. 65-70, Feb, 1993.

WOLBARST, M. Laser surgery: $\mathrm{CO}_{2}$ or HF. IEEE. J Quantum Electron, New York, v. 12, p. 1427-32, 1984.

YAMADA, R. S.; ARMAS, A.; GOLDMAN, M. A scanning electron microscopic comparison of a high volume final flush with several irriganting solutions: part 3. J. Endod., Chicago, v. 9, n. 4, p. 137-42,1983.

ZAKARIASEN, K. L. Shedding new light on lasers. J. Am. Dent. Assoc., Chicago, v. 124, February, 1993.

ZEZELL, D. M.; CECCHINI, S. C. M.; PINOTTI, M.; EDUARDO, C. P. Temperature changes under Ho: YLF irradiation. SPIE, Bellingham, v. 2672, p. 1115-1120, 1996.

ZHANG, C.; KIMURA, Y.; MATSUMOTO, K.; HARASHIMA, T.; ZHOU, H. Effects of pulsed Nd: YAG laser irradiation on root canal wall dentin with different laser initiators. $\mathbf{J}$. Endod., Chicago, v. 24, n. 5, p. 352-355, 1998.

ZMENER, O.; SPIELBERG, C.; OLMOS, J. Effectiveness of two different methods for preparing curved root canals. End. Dent. Traumatol., Copenhagen, v. 10, n. 5, p. 215-219, Oct. 1994.

ZMENER, O; BANEGAS, L. Effectiveness of nickel-titanium files for preparing curved root canals. Endod. Dent. Traumatol., Copenhagen, v. 11, n. 3, p. 121-123, 1996. 